(1I) Nordic Council of Ministers

\title{
Nordic Tourism Policy Analysis
}

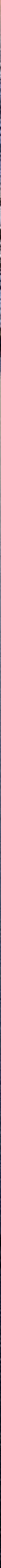


Nordic Tourism Policy Analysis

Ragnheiður Elín Árnadóttir

Nord 2019:008

ISBN 978-92-893-6058-6 (PRINT)

ISBN 978-92-893-6059-3 (PDF)

ISBN 978-92-893-6060-9 (EPUB)

http://dx.doi.org/10.6027/Nord2019-008

(c) Nordic Council of Ministers 2019

Layout: Gitte Wejnold

Cover Photo: Per Peterson, imagebank.sweden.se

Print: Rosendahls

Printed in Denmark

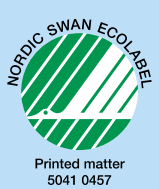

\section{Nordic co-operation}

Nordic co-operation is one of the world's most extensive forms of regional collaboration, involving Denmark, Finland, Iceland, Norway, Sweden, the Faroe Islands, Greenland, and Åland.

Nordic co-operation has firm traditions in politics, the economy, and culture. It plays an important role in European and international collaboration, and aims at creating a strong Nordic community in a strong Europe.

Nordic co-operation seeks to safeguard Nordic and regional interests and principles in the global community. Shared Nordic values help the region solidify its position as one of the world's most innovative and competitive.

\section{Nordic Council of Ministers}

Nordens Hus

Ved Stranden 18

DK-1061 Copenhagen $\mathrm{K}$

www.norden.org

Download and order Nordic publications from www.norden.org/nordpub 


\section{Nordic Tourism Policy Analysis}




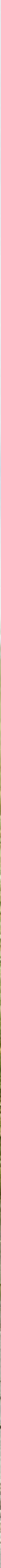




\section{CONTENTS}

$\begin{array}{ll}6 & \text { Foreword } \\ 9 & \text { Introduction } \\ 10 & \text { Key Recommendations }\end{array}$

\section{SECTION I: SETTING THE SCENE \\ The Global Impact of Tourism}

Trends and Megatrends in Tourism

Nordic Tourism Structures and Collaboration

Tourism Organisational Framework in the Nordic Countries

Denmark

Finland

Iceland

Norway

Sweden

Åland Islands

Faroe Islands

Greenland

The Big Picture

Nordic Organisational Structures and Tourism Policies - A Few Observations

\section{SECTION II: COMMON THEMES AND FOCUS AREAS \\ Digitalisation and Smart Nordic Destinations}

Digital Technology as a Driver for Nordic Innovation

Focus on Digitalisation

Challenges on the Way to Digitalisation

Smart Nordic Destinations

Recommendations

\section{Sustainable Development in Tourism}

Sustainability - The Key to Nordic Tourism

The Politics of Sustainability

The Nordic Council of Ministers' Agenda on Sustainability

The Carbon Footprint of Tourism

Solutions Through Innovation and Technology

Nordic Best Practices

Recommendations

Marketing Nordic Destinations

Collaboration and Competition

Long-haul Markets

Recommendations

Seasonality, Destinations and Competitiveness

Seasonality - A Common Nordic Challenge

Destination Management Planning

Sharing Knowledge and Best Practices

Business Innovation and Competitiveness

Recommendations

\section{SECTION III: RECOMMENDATIONS AND CONCLUSIONS}

Increased Nordic Co-operation on Tourism or Not?

Recommended Organisational Structures

Nordic Task Force on Tourism and Nordic Tourism Facilitator

66 List of Experts Interviewed

68 References

70 Internet Sources 


\section{Foreword}

It is with great pleasure that I present the Nordic Tourism Policy Analysis Report to the Nordic Council of Ministers. I was invited by the Icelandic Minister of Tourism, Industry and Innovation, on behalf of the Nordic Business Ministers, to lead this project as the Head Consultant in February of 2018. I want to thank the Nordic Council of Ministers for entrusting me with this interesting task and sincerely hope that this work will be beneficial and add value to the tourism sector in the Nordic region. I give particular thanks to Berglind Hallgrímsdóttir, my partner in this project, for her expertise, hard work and excellent collaboration.

Tourism is an important, growing industry in all the Nordic countries, but until recently, it has not had a particularly strong focus within the Nordic cooperation framework. This is changing rapidly, and the Nordic Council of Ministers has given a strong signal in recent years that increased emphasis should be placed on tourism issues within the Nordic framework. This project is a result of that important political prioritisation by the ministers.

The first task was to explore whether there is real interest, willingness and need among tourism actors within the Nordic countries for increased formal Nordic cooperation on tourism, both within and between the public and the private sectors. And if so, to identify possible areas where Nordic cooperation could make a real difference and add value to the efforts that are already underway in each of the countries. The objective was also to provide recommendations regarding specific projects and focus areas where Nordic collaboration would be of particular value and to identify the potential organisational structure for the cooperation.

My conclusion is clear. There is interest, will and need for increased Nordic cooperation within the tourism sector. There is much to gain, as the Nordic countries are facing many of the same challenges even though they are at different stages in the development of the industry. The countries have much to learn from each other. Knowledge sharing and information exchange were in fact mentioned in almost all of the interviews as a natural venue for cooperation. Other common themes kept reoccurring, such as digitalisation, sustainability, innovation and marketing, and the report provides detailed analysis on these issues and recommendations on concrete projects which could be beneficial from Nordic and national perspectives.

It is also clear that there is no room within the Nordic tourism sector for formal cooperation just for the sake of the cooperation. It has to be effective and relevant and add value. The call is for practical solutions and building on existing national and Nordic organisational structures. Yet someone has to take the initiative and shoulder the responsibility of the cooperation. With that in mind, my proposal is for a Nordic Task Force on Tourism to be established on the grounds of the existing ad hoc Nordic Working Group on Tourism and for a Nordic 
Tourism Facilitator to be appointed as a coordinator with a clear political mandate, reporting to both the Nordic Business Ministers and the Task Force. The goal is to strike the right balance between having a simple organisational structure and ensuring that the responsibility for the issue remains clear.

This analysis involved research on the existing literature on Nordic tourism: national policies and legislation, academic reports, industry analysis and other information relevant to Nordic tourism. Berglind and I travelled the Nordic region and met with experts from all of the Nordic countries: ministers, other representatives from ministries, visitor organisations, industry organisations, private tourism companies, local governments, consultants, Nordic institutions and labour organisations to name a few. Numerous Skype meetings were conducted with Nordic experts all over the region, creating a very long list of people who need to be thanked for their assistance, expertise and willingness to cooperate.

There are opportunities and challenges ahead for Nordic tourism. The impact of the sector on the Nordic region is already very significant and is only likely to increase in importance and scope. I hope that this policy analysis will have a positive impact and lead to constructive developments for tourism in the Nordic region.

Ragnheiður Elín Árnadóttir

Former Minister of Industry and Commerce in Iceland 


\section{Introduction}

\section{Background}

In 2016, the Nordic Ministers for Cooperation (MR-SAM) launched a reform process aimed at improving Nordic cooperation. A key issue in the reform process was Nordic collaboration on tourism, with the objective of increasing competitiveness, innovation and sustainability within the sector. The ministers proposed that tourism should be prioritised within the framework of Nordic collaboration. The recommendation was taken up by the ministers for Business, Energy and Regional Policy (MR-NER) in Helsinki 2016, where it was decided to prioritise tourism. At their next meeting in Bergen on 17 May 2017, the Nordic Business Ministers decided to establish a working group responsible for making a Nordic plan for increased tourism collaboration in order to explore which areas of Nordic collaboration would create additional value.

The proposal to undertake a Nordic Tourism Policy Analysis (NTPA) is a product of this political prioritisation.

\section{Mandate}

According to the mandate of the NTPA project, the aim is to map and analyse current Nordic tourism policies, framework conditions and other relevant public activities, as well as to define panNordic challenges and areas for further Nordic collaboration. Defining a framework for future formal tourism cooperation will also be addressed.

Until now, the Nordic approach to tourism has mainly been ad hoc. This policy analysis is expected to build a foundation for future undertakings within the field, define future strategies and projects and map common opportunities and challenges within the Nordic countries with respect to this growing industry.

\section{Objective}

The key objective of this project is to create a framework on which a Nordic Tourism Strategy can be established. Thus, the desired outcome of the project is to define future strategies and projects that will underscore common opportunities and challenges within Nordic tourism. The objective of a Nordic Tourism Policy Analysis is to provide valuable input to each country's work within tourism as well as laying a foundation for a common Nordic Tourism Plan. 


\section{Key Recommendations}

The analysis strongly indicates that there is real potential to add value for tourism in the Nordics by strengthening Nordic cooperation in the sector. There are common themes and challenges that the countries share, which resonate strongly with key themes in national tourism strategies and national and Nordic business and innovation policies.

Following is a list of the key recommendations and projects within these themes, as well as a proposed organisational structure.

\section{Digitalisation and Smart Nordic Destinations}

- In order for Nordic tourism to realise the growth promised by new technologies, Nordic ministers are encouraged continue to prioritise digital development and technological innovation in tourism. A strong political mandate is needed to facilitate the necessary alignment of regulations, cross-border collaboration and implementation of policies that encourage greater information and data sharing.

- In order to facilitate a more rapid digital development in Nordic tourism, the initiative should be taken to pool resources and build on the extensive work which has already been carried out on digitalisation policies in the different Nordic countries.

- A forum for new and disruptive ideas within digital tourism, with a focus on smart destinations, smart mobility and connectivity, should be created. This is an opportunity to draw on the experience, expertise and work of key actors within the tourism sector, such as PALTA in Finland, Dansk Industri and others.

- Drawing on international experience, a Nordic network and action plan for Smart Destinations should be established. The objective of the network would be to develop guidelines for regional and local authorities, tourist companies and SMEs on how to become a smart destination, building on digital means and destination development.

- A Nordic collaborative project on tourism statistics and mobile data has already been proposed by the Swedish Agency for Economic and Regional Growth, in collaboration with Innovation Norway. The project is an important first step and further cooperation should be supported.

- Best practice cases of smart and effective uses of digital technology from destinations and tourism businesses should be collected in order to facilitate knowledge transfer. This can provide an assessment of key competences and actions which have the potential to strengthen digital competence in Nordic SMEs and destinations.

- A Nordic network focusing on Traveltech should be established. This network could become a platform through which to identify and activate collaboration between public and private actors, technology developers and investors.

\section{Sustainable Development in Tourism}

- As political backup and prioritisation is crucial to sustainable development in the Nordic tourism sector, Nordic ministers are encouraged to set clear objectives and priorities for collaboration on sustainability goals in tourism, both on national and Nordic levels.

- Nordic ministers are encouraged to support the Nordic countries in developing a methodology for sustainable tourism strategies, followed by action plans and a monitoring scheme. This 
recommendation is in line with proposal 13/12B in the report "Sustainable Production and Consumption" published by the Nordic Council of Ministers. 'Developing and implementing tools to monitor the impact of tourism by tracking the impact it has at various levels is an important requirement for more effective tourism policy development and destination management in the Nordics.

- A Nordic roadmap for sustainable tourism should be created and ambitious and measurable goals set, where regulations and infrastructure in tourism supports environmental objectives and sustainability of the sector. Better use can be made of already existing resources on a Nordic and national level trough Nordic cooperation. A taskforce for effective exchange of best practices and policies should be established to facilitate this. The role of the taskforce would also be to outline challenges and explore and mobilise action.

- An effort must be made to encourage innovation, business development and new business models in the tourism sector to accelerate the transition towards sustainability of the sector. Existing organisational structures should be used to facilitate this, but new Nordic networks for knowledge sharing and best practice must be facilitated. An effort should be placed on cutting through barriers within Nordic and national organisations to access expertise and facilitate cooperation. The establishment of a Nordic Traveltech network can also contribute to this objective.

\section{Marketing Nordic Destinations}

- The collaboration between the Nordic Visit Organisations should be continued.

Cooperation on developing long-haul markets is the obvious topic of mutual interest.

- Opportunities for developing the Nordic brand further should be explored in closer cooperation with the tourism sector.

- An evaluation should be carried out of whether existing structures, such as Vestnorden and NATA, could be used as models for successful cooperation for the Nordic region.

- The necessary marketing efforts to encourage long-haul visitors to stay longer and travel between Nordic destinations should be explored, not least with the objectives of tackling the environmental impact of long-haul tourism and the importance of sustainability goals.

\section{Seasonality, Destinations and Competitiveness}

- An effort must be made to encourage innovation, business development and new business models in the tourism sector to accelerate the transition towards sustainability and growth within the sector.

- Collaboration between Nordic tourism support agencies should include knowledge sharing, data exchange and market research. A special emphasis should be placed on collecting statistical information across the Nordic region with comparable indicators. 
- DMP projects have already led to improvements within the Nordic region, but much still needs to be done to strengthen competence and business in the tourism sector. A more decisive long-term strategy, backed up by professional support, is necessary at the level of individual SMEs, networks and regions. There are plenty of good practices and tools in the Nordic "toolbox" for DMP. These need to be shared more effectively and developed further.

\section{Organisational Structures}

In order to best facilitate Nordic cooperation on tourism in a way that accommodates the analysis in this report, as well as the priorities and views of Nordic tourism experts interviewed, the recommendation is to set up an organisational framework that supports several objectives at once: a lean structure, but with a clearly defined responsibility, commitment and mandate, involving both public and private sectors from the Nordics.
The recommendation is twofold, to create a Nordic Task Force on Tourism and a position of a Nordic Tourism Facilitator who will report to both the Nordic Council of Ministers and the Task Force.

The facilitator will have the main objective to identify areas of cooperation relating to tourism; initiate, follow-up and navigate tourism issues through the Nordic system, and work with national governments and private sector tourism actors on specific projects.

The Task Force should have representatives from all of the Nordic countries and the autonomous regions, from both the public and private sectors. Together, the facilitator and the Task Force will remove silos and simplify communication channels and be able to secure a cross-national and crosssectoral tourism focus on relevant projects that are of mutual Nordic interest and concern. 


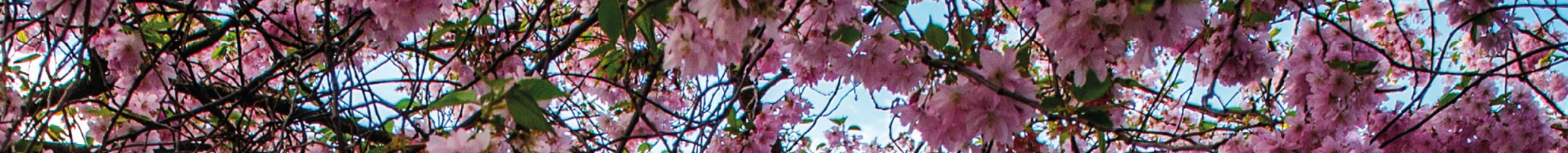

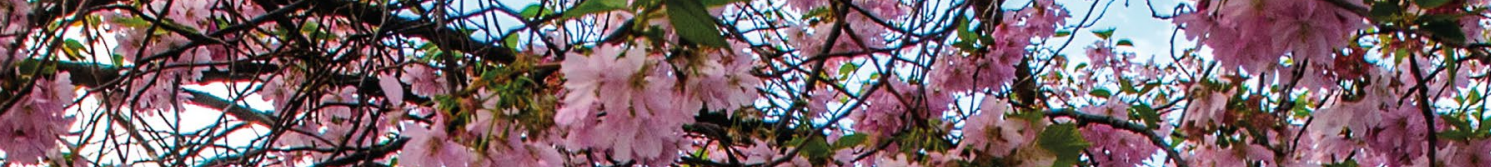

2.1.

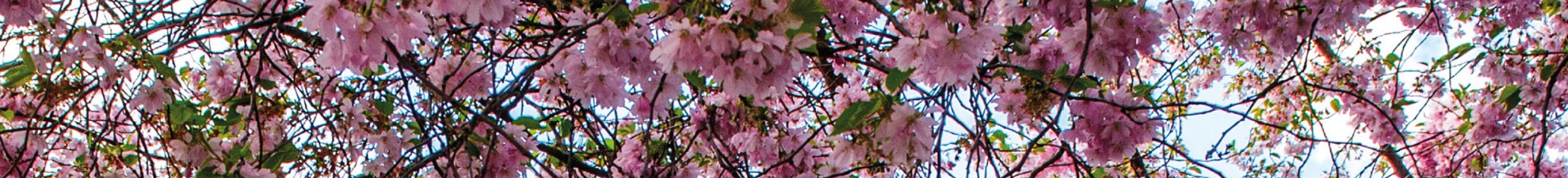

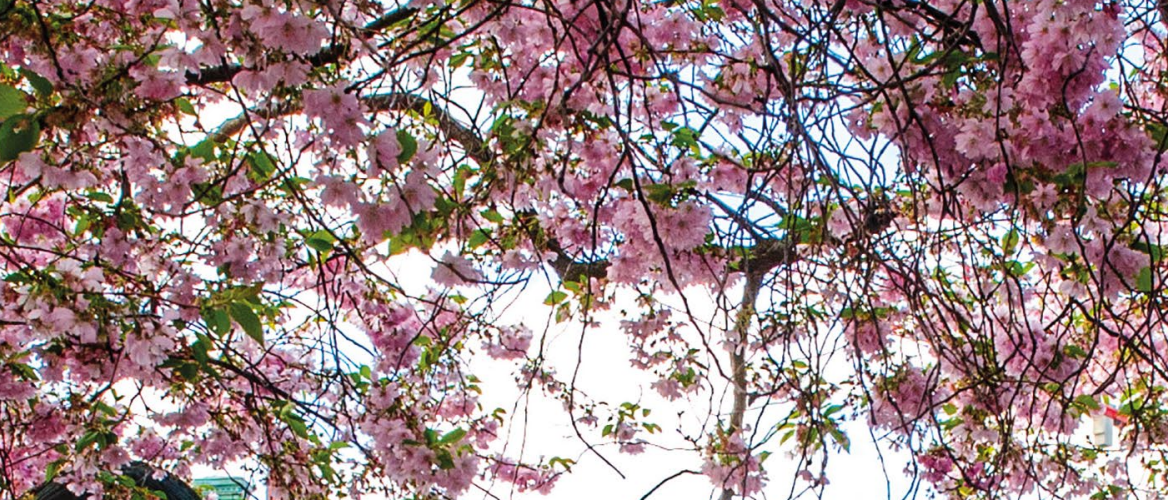

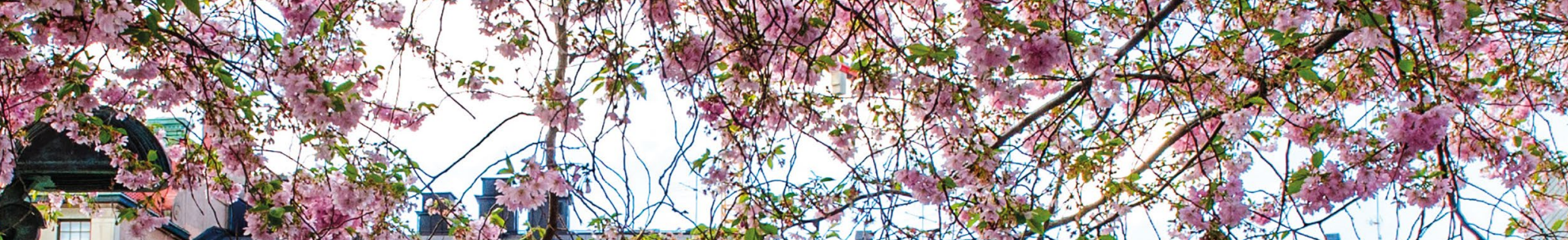

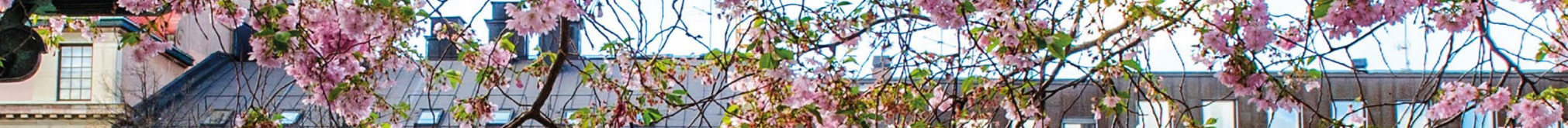

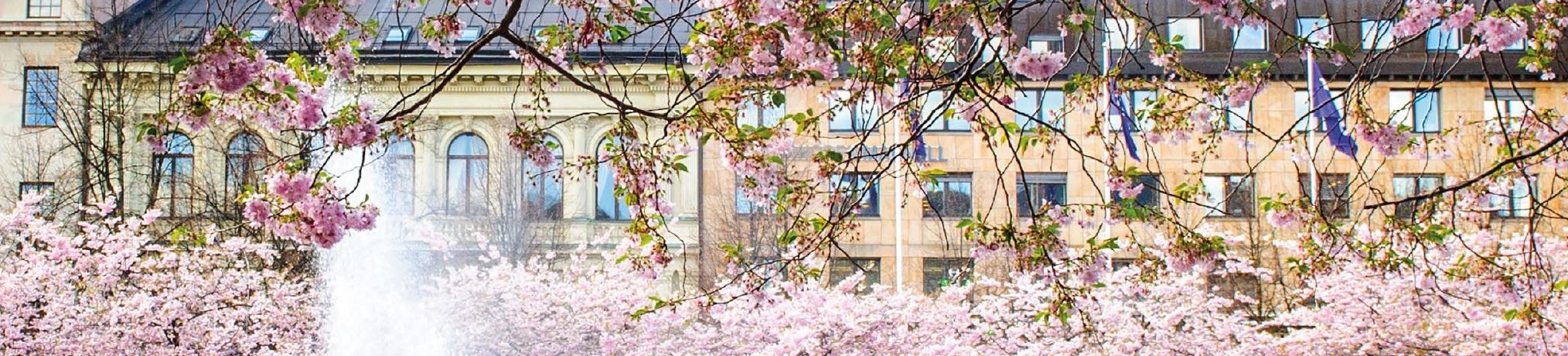

$4 \sin 4 x+20$ Antan

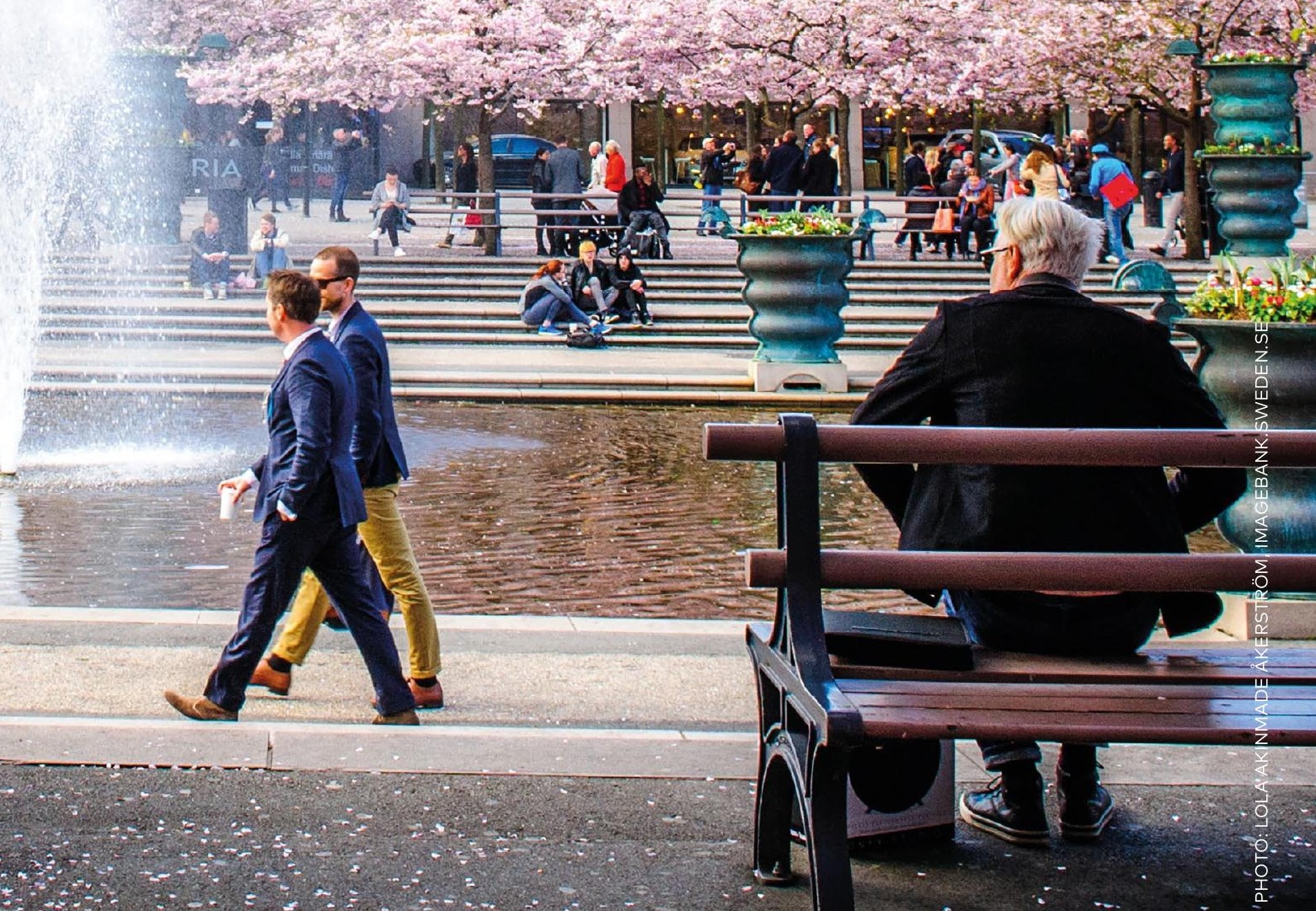




\section{a \\ SETTING THE SCENE}

\section{The Global Impact of Tourism}

Globally, the economic importance of tourism is significant and growing. Tourism is already one of the largest and fastest growing sectors in the world economy, with an important contribution to job creation, export revenue and domestic value added. International organisations and national governments alike have come to see tourism as a driver of economic growth and future development.

According to OECD Tourism Trends and Policies 2018 , the average economic impact of tourism is $4.2 \%$ of GDP, $6.9 \%$ of employment and $21.7 \%$ of service exports in the OECD countries. ${ }^{2}$ Expenditure on travel more than doubled globally between 2000 and 2016 , amounting to $7 \%$ of global exports in goods and services. ${ }^{3}$

International tourist arrivals reached 1,323 million in 2017, making it a record year for international tourism. This is a growth of 84 million international arrivals, or 7\% more than in 2016. Tourism has grown at around $4 \%$ per year for eight consecutive years, a growth which is unparalleled since the 1960s. From 2014, the Nordic region had an annual growth of $6-8.5 \%$ in the number of bed nights. ${ }^{4}$ The highest growth in international tourist arrivals in 2017 was in Africa, with a 9\% increase. Europe also experienced significant growth in 2017, with an $8 \%$ increase in tourist arrivals. Between 2005 and 2016, Asia outperformed all world regions in terms of growth, with international tourists arrivals increasing on average by $7 \%$ per year, compared to the aforementioned international average of $4 \% .^{5}$

Growth in the range of $3.5-7 \%$ is forecast in international tourist arrivals in all regions in 2018. ${ }^{6}$ Continued long-term growth is expected, with international arrivals estimated to reach 1,800 million in 2030.?

\section{Trends and Megatrends in Tourism}

The tourism sector is placed at the extreme end of both the local and the global. It permeates economic, social, cultural and environmental conditions at all levels. The interaction of the global impact of tourism and the extent of its infiltration into the local backdrop makes the sector an important driver for change. This represents, at the same time, enormous opportunities and challenges. The tourism sector has a great potential for creating economic growth and development, while at the same time posing real challenges to communities, culture and the environment.

While tourism can have a huge and disruptive impact on local communities and economies, the sector itself is susceptible to changes and trends; it is challenged by diverging interests and is both fragmented and diverse. There is strong awareness in all the Nordic countries of the complex interplay

\footnotetext{
2 OECD (2018). OECD Tourism Trends and Policies 2018, OECD Publishing, Paris. http://dx.doi.org/10.1787/tour-2018-en, 27-28.

${ }^{3}$ World Tourism Organization, UNWTO, (2017). Tourism Highlights. 2.

${ }^{4}$ Statistics Iceland. (2019).

${ }^{5}$ World Tourism Organization, UNWTO, (2017). Tourism Highlights. 15.

${ }^{6}$ World Tourism Organization, UNWTO (2018). Annual Report 2017, 9-16.

${ }^{7}$ Statens offentliga utredningar, SOU (2017). Ett land att besöka. En samlad politik för hållbar turism och växande besöksnäring. Betänkande av

Utredningen Sveriges besöksnäring, Statens offentliga utredningar, Stockholm 2017, 49.
} 


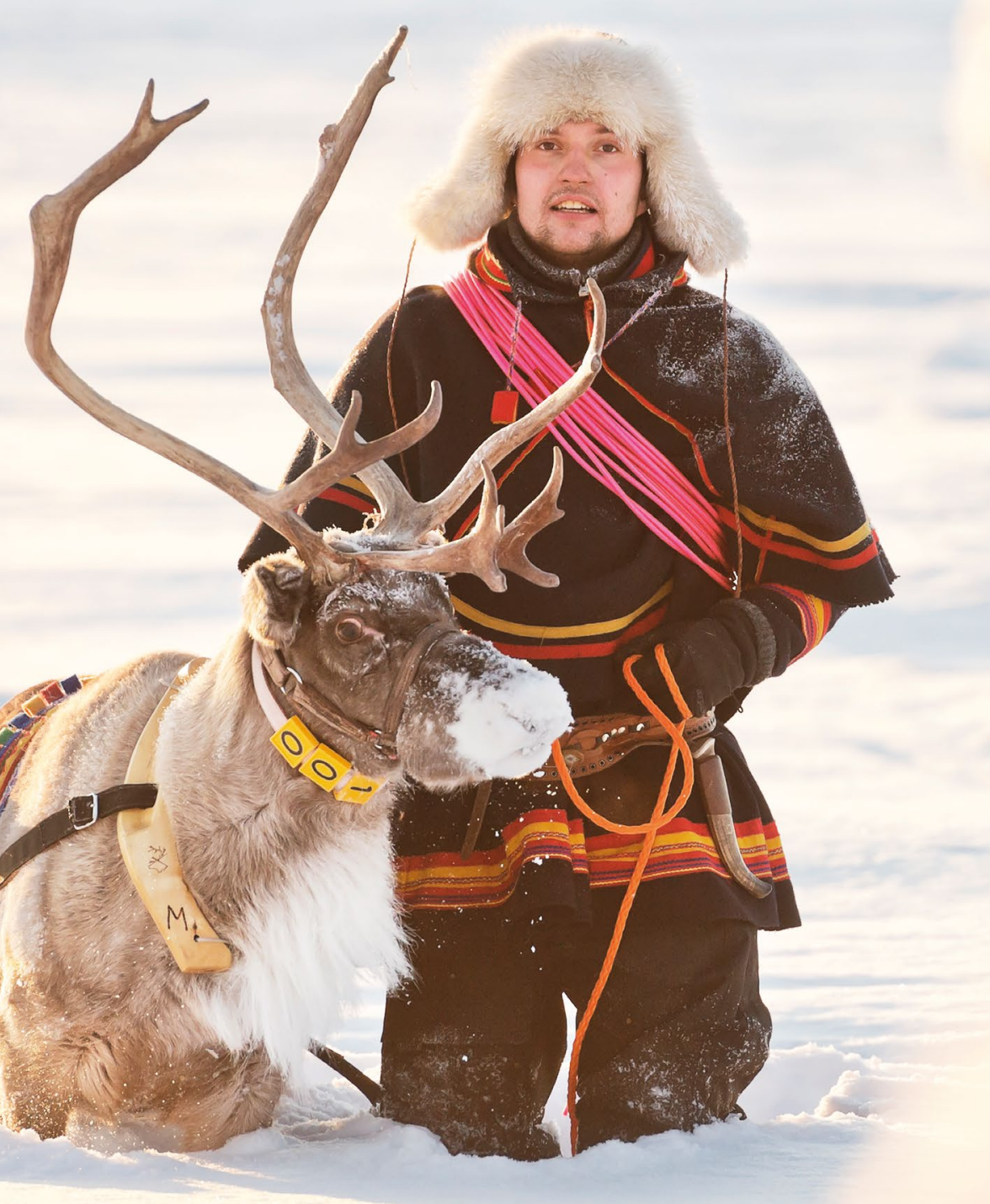

and often conflicting interests within tourism. In all the countries, the sector has gained increased political importance because of its growing current and future economic impact.

Major global trends are currently shaping and changing the global tourism industry. Although their impact may differ throughout the region, these same global trends are the most important drivers of change for Nordic tourism. Among the most evident trends are changing demographics among travellers and the emergence of new markets, digitalisation and new and disruptive business models, as well as social, cultural and environmental challenges. The impact of these trends and megatrends was evident in interviews with key players within the Nordic tourism industry throughout the region.

There is a wealth of knowledge among professionals within the sector, and many examples of successful measures to address specific challenges faced by regions and countries in the Nordics. These challenges need to be addressed in a strategic and effective way that will facilitate dynamic change and increased competitiveness. Bringing together Nordic experience and expertise could be an important catalyst to speed up this development. There are no easy solutions. Any policy on tourism, or framework for collaboration must be able to deal with the complexity of the sector and the many converging interests it represents. 


\section{Nordic Tourism Structures and Collaboration}

There is no permanent formal structure for collaboration in tourism within the main forums for official Nordic cooperation. Despite this, certain collaboration has taken place in recent years through individual projects, mostly informal and not coordinated. The most notable exception is the Scandinavian Tourist Board, where Norway and Denmark have joined forces in marketing efforts on Asian markets.

The Nordic Council of Ministers' secretariat in Copenhagen has one staff member working specifically on tourism, part time, on behalf of the Nordic Business Ministers. The Nordic Council has a tourism focus within its inter-parliamentary Committee on Growth and Development in the Nordic Region. Due to encouragement from the Nordic Business Ministers, there has recently been more emphasis placed on tourism within the Nordic organisation Nordic Innovation, with its main role being to promote cross-border trade and innovation. Most experts who were interviewed in all the countries, from both the public sector and industry, agree that the aim should be to use existing Nordic structures and staff rather than to create a new Nordic institution which would focus on tourism.

Another reflection of the importance of the tourism industry in the Nordic region is the focus on tourism during the Icelandic presidency of the Nordic Council of Ministers in year 2019. Special emphasis will be put on sustainable tourism, with particular focus on climate and environment, harnessing local resources and digitalisation.

The Visit Organisations in all the Nordic countries have perhaps had the most formal cooperation throughout the years, they have met regularly once or twice a year to exchange information and cooperate on specific issues, such as:

- Monitoring results from marketing campaigns

- Collaborating on purchasing research and data

- Analysing visitor behaviour (e.g. mobile data)

- Coordinating success indicators for destinations

- Comparing visitor surveys and market surveys

- Sharing intelligence on evaluation of specific markets

- Information sharing and evolution of trends

There is also industry-specific cooperation within the Nordic countries, for instance collaboration between industry organisations from each country. They meet regularly several times per year to discuss common Nordic interests as well as common representation within larger industry organisations such as Hospitality Europe, (HOTREC), which is an umbrella association of hotels, restaurants, bars and cafés, bringing together 43 national associations in 30 European countries. ${ }^{8}$ Common Nordic representation visa-vis the European Union was also mentioned as an important issue by the industry organisations, where it is felt that the Nordics can guard common interests more successfully by having a united front.

The three West Nordic countries, Greenland, Iceland and the Faroe Islands, have cooperated formally on tourism through the North Atlantic Tourism Association (NATA). NATA, with a secretariat based in Tórshavn, was established in 2006 by combining three organisations: the West Nordic Tourist Board, SAMIK and FITUR. As outlined on NATA's website, its vision is: 


\section{Tourism Organisational Framework in the Nordic Countries}

Following is a description of the organisational framework, regulatory environment and national tourism policies in the five Nordic countries and the autonomous areas of Åland Islands, Faroe Islands and Greenland.

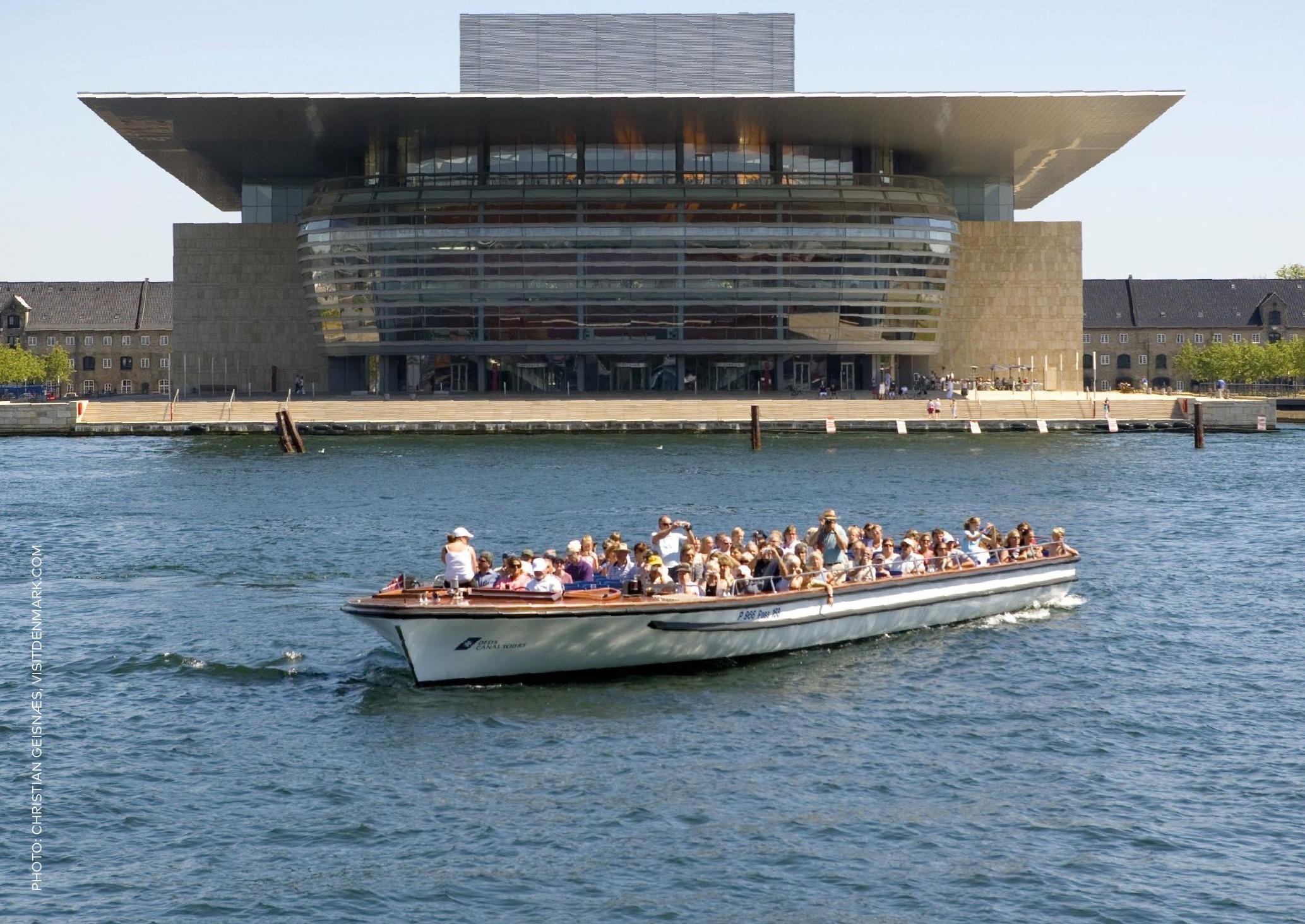




\section{DENMARK ${ }^{10}$}

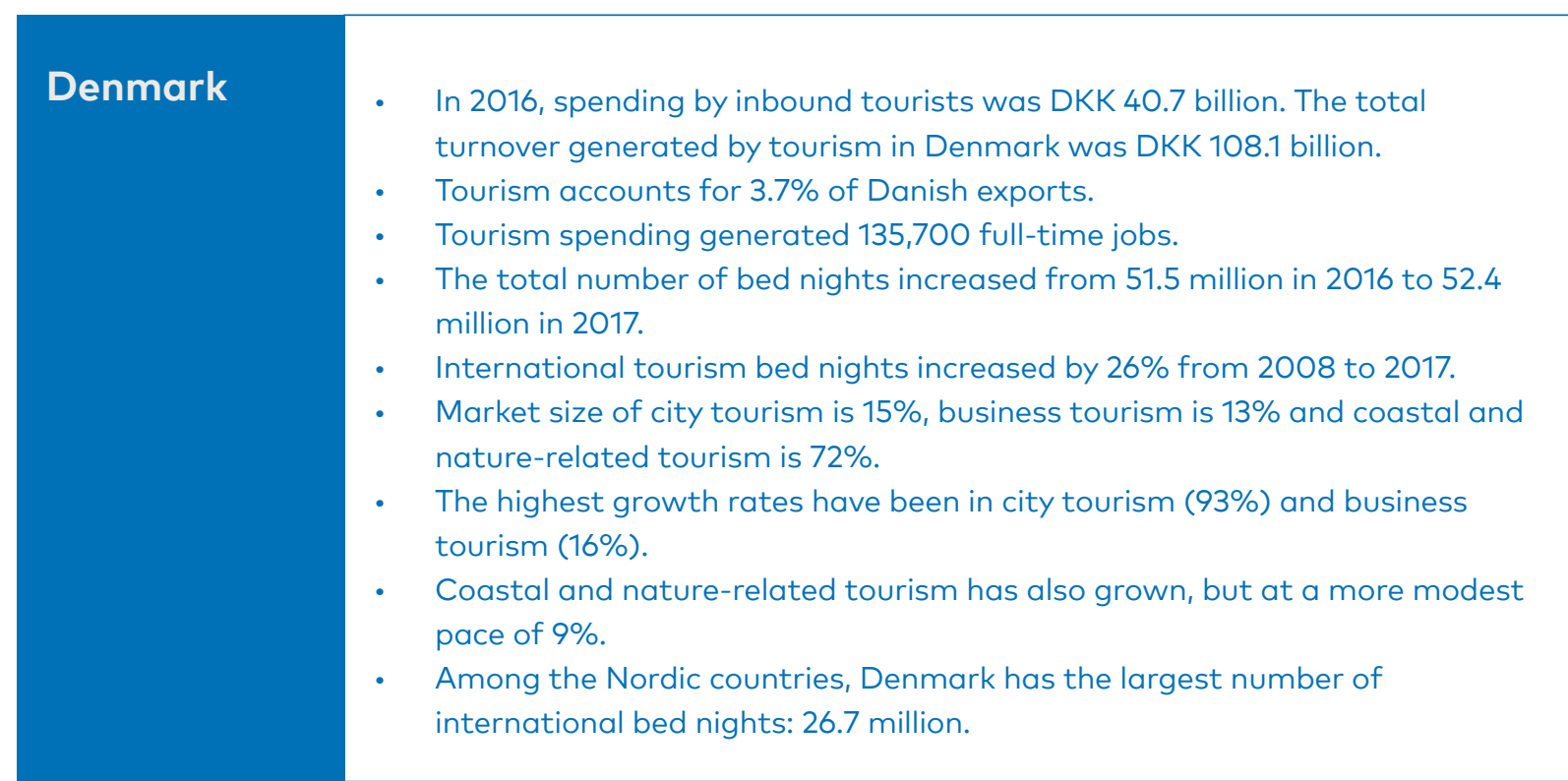

\section{Governance and Legislation:}

Tourism falls under the responsibility of the Ministry of Industry, Business and Financial Affairs.

With a legislation from 1 January 2015, structural changes were made to the tourism organisational structure in Denmark. The Ministry cooperates with several other ministries in the Danish government on issues relating to tourism, including the Ministry of the Environment and Food, Ministry of Transport, Building and Housing, the Foreign Ministry, and the Ministry of Culture.

The Danish National Tourism Forum was established to strengthen and coordinate collaboration within the tourism sector in Denmark. The Forum is chaired by the State Secretary of the Ministry of Industry, Business and Financial Affairs and has seven additional members: VisitDenmark's chairman, two regional representatives, one from Local Government Denmark, two representatives from the tourism industry and one member from academia. In 2016, the National Tourism Forum developed a Danish national tourism strategy until 2025. From 1 January 2019, the National Tourism Forum has been widened to also include the Chairman of Danish Coastal and Nature Tourism and the Chairman of Wonderful Copenhagen.

The Danish Tourism Advisory Board was also established under the legislation to advise and support the National Tourism Forum. It is also chaired by the State Secretary of the Ministry of Industry, Business and Financial Affairs and has 17 additional members and one observer, representing a broad selection of tourism sector stakeholders, including two ministries and both public and private sectors.

\footnotetext{
10 Sources:

1) Erhvervsministeriet. (2016). Growth in Denmark. Danish Tourism 2025. A National Strategy for Danish Tourism - In Brief. (Unofficial translation), 3.

2) OECD. (2018). OECD Tourism Trends and Policies 2018. OECD Publishing.

3) Erhvervsministeriet. (2016) Turismestrategier for de nordiske lande. (Unpublished draft).

4) Erhvervsministeriet. (2014) Danmark i arbejde. Vækstplan for dansk turisme.
} 


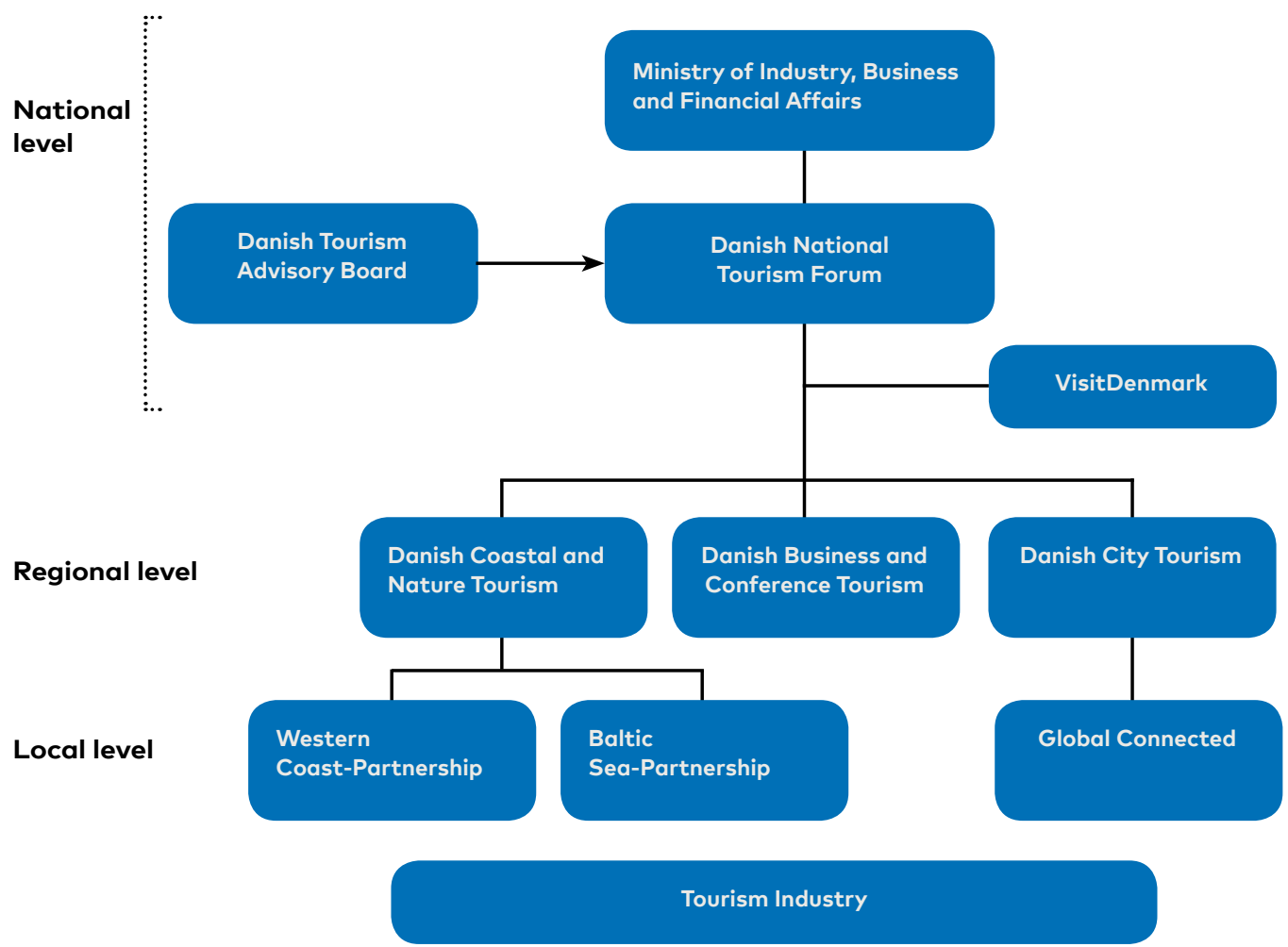

Source: OECD, adapted from Ministry of Industry, Business and Financial Affairs, 2018

Footnote: Danish tourism organisational structure is changing. New organisational chart will be available in early 2019.

Three tourism development agencies were set up specifically focusing on the different types of tourism under the national tourism strategy:

\section{Coastal and Nature Tourism, Business and Conference Tourism and City Tourism.}

International marketing and branding of Denmark is managed by VisitDenmark, which also conducts market research and related activity. VisitDenmark cooperates with the ministry and different tourism agencies, and the National Tourism Forum has the coordinating role.

\section{Policies and Strategy:}

In 2016, the "Danish National Tourism Strategy

2025" was developed by the Danish National
Tourism Forum, setting a common direction towards 2025 and bringing together public and private stakeholders in the tourism sector for close cooperation in concerted strategic action.

The point of departure among the participants when creating the strategy was the following:

"Denmark strives to be an engaging tourist destination where we - together with our guests create a variety of quality experiences, always with a human touch and never far away".11 


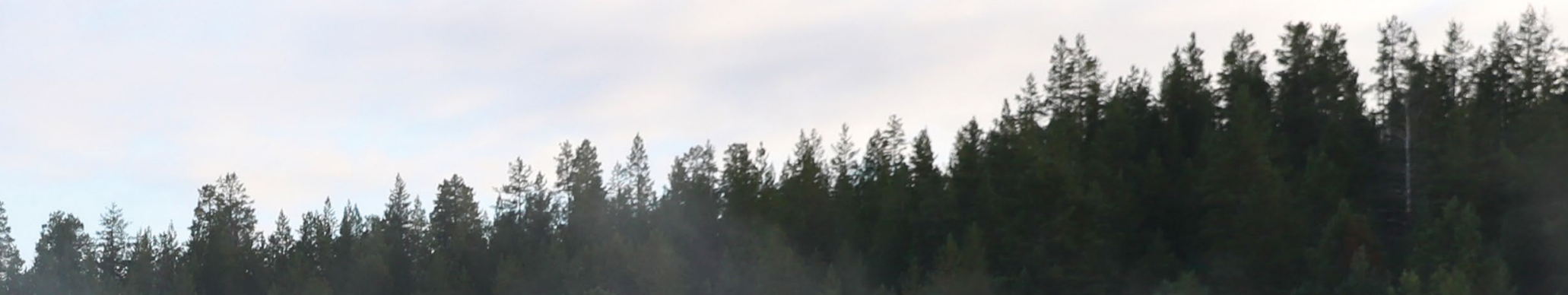

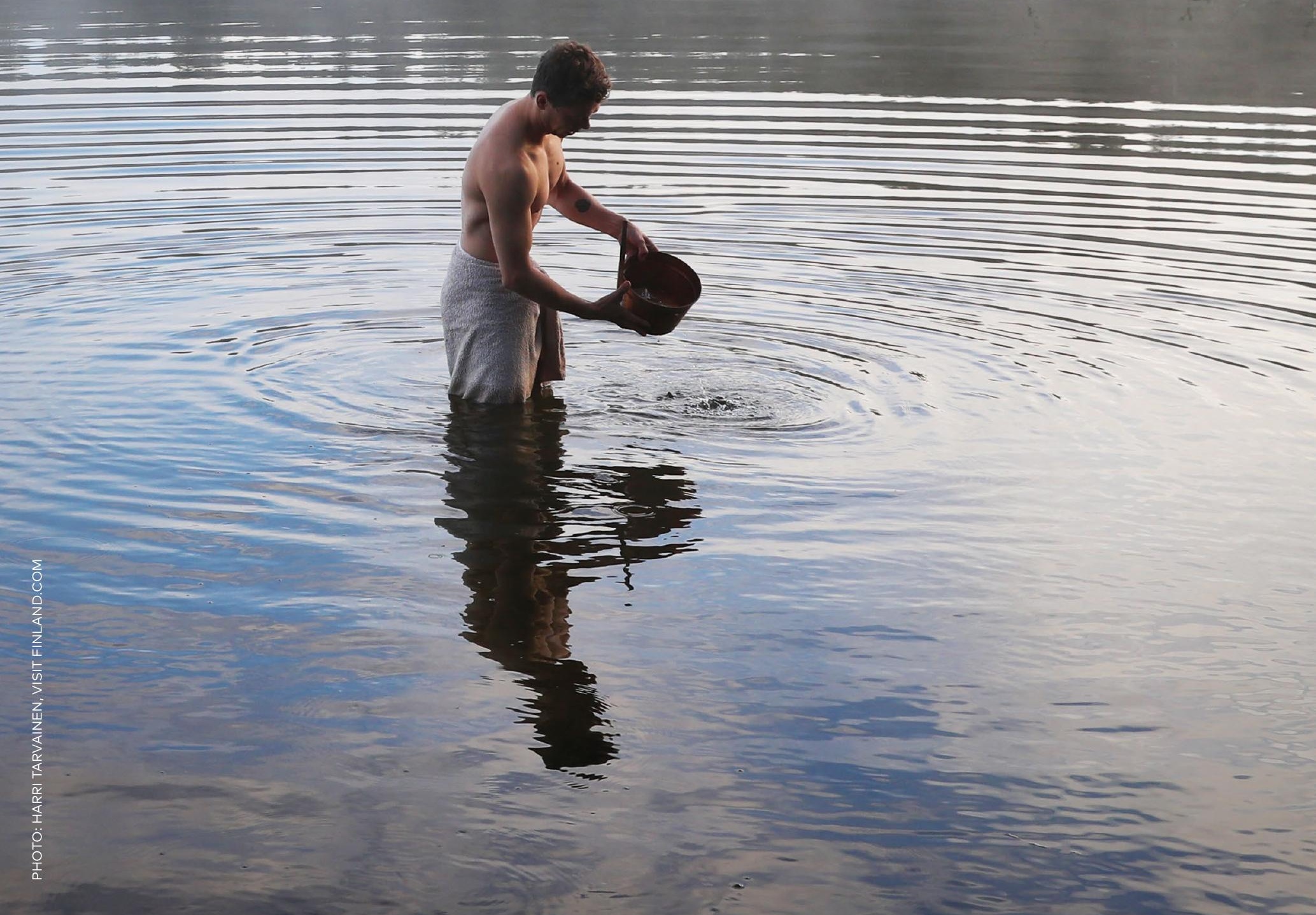




\section{FINLAND ${ }^{12}$}

\begin{tabular}{|c|c|}
\hline Finland & $\begin{array}{l}\text { - In Finland, tourism has grown more than other sectors and is recognised as } \\
\text { an important contributor to economic growth and job creation. } \\
\text { - The number of international travellers has doubled since year } 2000 \text {. } \\
\text { Export earnings by international tourism are estimated to be EUR } 4.4 \\
\text { billion in } 2017 \text {. } \\
\text { - In } 2016 \text {, the value added generated by tourism amounted to EUR } 4.6 \text { billion, } \\
\text { or } 2.5 \% \text { of Finland's GDP. (Preliminary data). }\end{array}$ \\
\hline
\end{tabular}

\section{Governance and Legislation:}

The Ministry of Economic Affairs and Employment is responsible for tourism affairs in the government of Finland, and the responsible minister is the Minister for Economic Affairs.

\section{The Ministry of Economic Affairs and Employment} oversees tourism policy, tourism development and support measures. It prepares legislation on tourism and maintains international relations in regard to tourism.

In developing the tourism sector, the ministry works in close cooperation with actors in other ministries and administrative branches. The Inter-Ministerial Working Group on Tourism was established over 18 years ago to enhance the cooperation and communication between ministries regarding tourism policy. Its aim is to exchange information on tourism more effectively and to prepare tourismrelated matters for decision-makers. The working group meets several times a year and is one of the bodies monitoring and implementing Finland's tourism policy.

A Tourism Cooperation Group was set up in 2016 by the Ministry of Economy and Employment. The group was temporary and operated until end of 2018. The group consisted of 35 industry leaders representing different branches of tourism. Its main purpose was to define and prioritise, from the point of view of the industry and trade and labour market associations in the hospitality and service sectors, actions to promote the competitiveness of tourism, for inclusion in the next government programme. Visit Finland is a state-funded agency, responsible for international promotion of Finland as a tourist destination. It cooperates with regional marketing agencies, tourism companies and ministries in product development, research and marketing.

Visit Finland and the tourism industry conduct joint product campaigns and arrange familiarisation trips for foreign tour operators and the media in order to support the promotion of Finland as an attractive destination. Visit Finland is a unit of Business Finland, the Finnish innovation funding, trade, investment and travel promotion organisation. Business Finland employs 600 experts in 40 offices globally and in 20 regional offices around Finland.

The Regional State Administrative Agencies carry out all legislative implementation, steering and

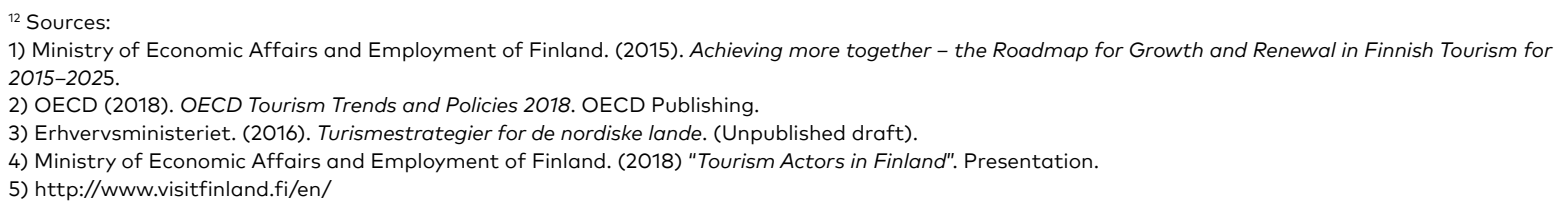




\section{Public Authorities}

Ministry of Economic Affairs and Employment

- Innovations and Enterprise Financing Department

- Promotion of Exports and Foreign Investments

National

level

level

Local

level
Inter-Ministerial Working

Group on Tourism
Regional State Administrative Agencies (6)
Centres for Economic Development, Transport and the Enviroment (15)

\section{Regional Councils (18)}

Municipalities (311)

\section{Tourism Organisations}

Visit Finland/Business Finland

Tourism Industry, Trade and Labour Market Associations

Regional Tourist and Destination

Management Organisations

Local Tourist Information Offices

Tourist Destinations and Offices

Source: OECD, adapted from the Ministry of Economic Affairs and Employment, 2018

supervisory functions in the regions. There are also about 30 regional tourism organisations in Finland, and these have varied objectives, tasks and ownership structures. Locally, tourism issues are handled by municipalities and local tourist information offices.

\section{Policies and Strategy:}

The current tourism strategy in Finland is the

\section{Roadmap for Growth and Renewal in Finnish}

Tourism for 2015-2025. The goal is for Finland to be the number-one tourist destination in Northern Europe by 2025 . The emphasis is on collaboration and the theme of the roadmap is "Achieving more together".
The strategic focus areas of the roadmap are:

- Collaboration and partnerships: Strengthening the theme-based collaboration of tourism centres and networks of tourism-related companies, as well as new openings in product development, sales, and marketing.

- Interesting offering: Developing competitive and versatile offerings from the interfaces of tourism and other fields.

- Increasing the effectiveness of marketing activities and making the travel services offered easier to buy. 


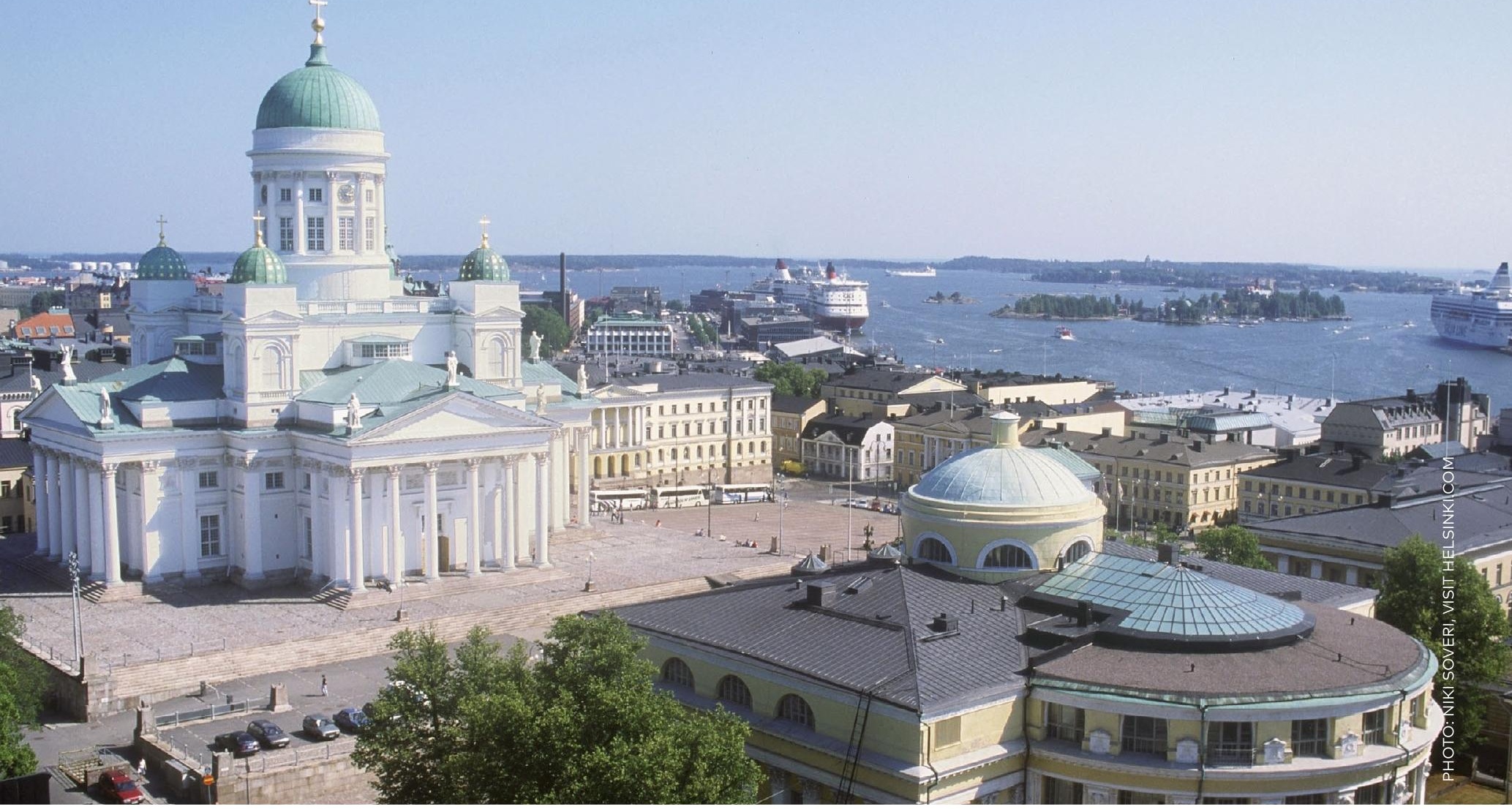

- A competitive operational environment for tourism that supports growth and renewal.

- Accessibility and functioning travel chains to support growth in tourism.

Specific tourism programmes and government initiatives in line with the roadmap include:

- Tourism 4.0 action programme 2018-2019 as a part of the Finnish government's action plan for 2017-2019.

- Finland Air Transport Strategy 2015-2030.

- Various cultural policies.

- A government report on food policy (Food 2030) where one of the objectives is to strengthen food tourism.

- Finland's updated (2017) Strategy for the Arctic Region and the related action plan which includes sustainable tourism as one of four priorities.

- Finland's updated (2017) Baltic Sea Strategy draws attention to the importance of sustainable and inclusive tourism.

- Growth programmes such as FinRelax, Finnish Archipelago and StopOver Finland incorporate various development, sales and marketing activities for implementation in 2015-2018.
The tourism strategy will be updated in the year 2019.

\section{Challenges:}

One of the challenges faced by tourism in Finland over the years is its poor price competitiveness. High taxes and labour costs are among the main reasons for this. Other challenges faced by the industry include seasonality, difficulties in finding skilled workers during the high season, connectivity issues and relatively few functioning travel chains to support growth in tourism.

Despite the challenges, Finland has recently gained a lot of positive attention and tourism numbers are growing fast. 


\section{ICELAND $^{13}$}

Iceland
- Iceland has experienced a far sharper growth than the other
Nordic countries.
- $\begin{aligned} & \text { Arrivals have grown annually on average by } 24.3 \% \text { since } 2010 . \\ & \text { Iceland received } 2.2 \text { million international tourists in 2017, representing } \\ & \text { a } 24.1 \% \text { increase on } 2016 .\end{aligned}$
- Around 2.3 million international tourists are estimated for 2018.
Tourism is now the leading export sector in Iceland, accounting for
ISK 462 billion (39\%) of total foreign currency revenue in 2016. The
importance of tourism now exceeds fisheries and aluminium combined.
Tourism employs 25,000 people in Iceland, which accounts for $14 \%$ of
the Icelandic workforce.
Tourism's direct contribution to GDP was $8.4 \%$ in 2016.
Bed nights at hotels and guesthouses in 2017 were 5.6 million,
$89.3 \%$ from international visitors.
The Reykjavík area accounted for $50.6 \%$ of hotel and guesthouse bed
nights in 2017.

\section{Governance and Legislation:}

Tourism falls under the responsibility of the Ministry of Industries and Innovation, and the minister responsible is the Minister of Tourism, Industry and Innovation.

The Icelandic Tourist Board (ITB) is an independent authority under the Ministry of Industries and Innovation, which administers tourism affairs according to the Tourism Administration Act from 2005. A new legislation has been approved in parliament and came into effect on 1 January 2019. The duties of the ITB include:

- Granting and monitoring of operating licenses to tourism businesses.

- Participating in the developing of the tourism regulatory framework.

- Conducting tourism research and statistics.
- Operating VAKINN, an official quality and environmental system.

- Regional development projects, such as developing Destination Management Plans (DMPs).

- Managing the Tourist Site Protection Fund.

The Iceland Tourism Council is appointed by the Minister of Tourism, Industry and Innovation and has ten representatives from the tourism sector, the ministry, regional and local authorities and Promote Iceland. Its role is to advise the minister on matters relating to tourism.

Promote Iceland is a self-governing public private partnership, established to lead the promotion and marketing of Iceland in foreign markets and stimulate economic growth through increased export. Seven board members are appointed for a three year term at an annual meeting. Minister for Foreign Affairs nominates two members, Minister

\footnotetext{
${ }^{13}$ Sources:

1) Ministry of Industries and Innovation and the Icelandic Travel Industry Association. (2015). Roadmap for Tourism in Iceland.

2) OECD (2018). OECD Tourism Trends and Policies 2018. OECD Publishing.

3) Erhvervsministeriet. (2016) Turismestrategier for de nordiske lande. (Unpublished draft).

4) www.ferdamalastofa.is

5) http://www.naturaliceland.is/en/
} 


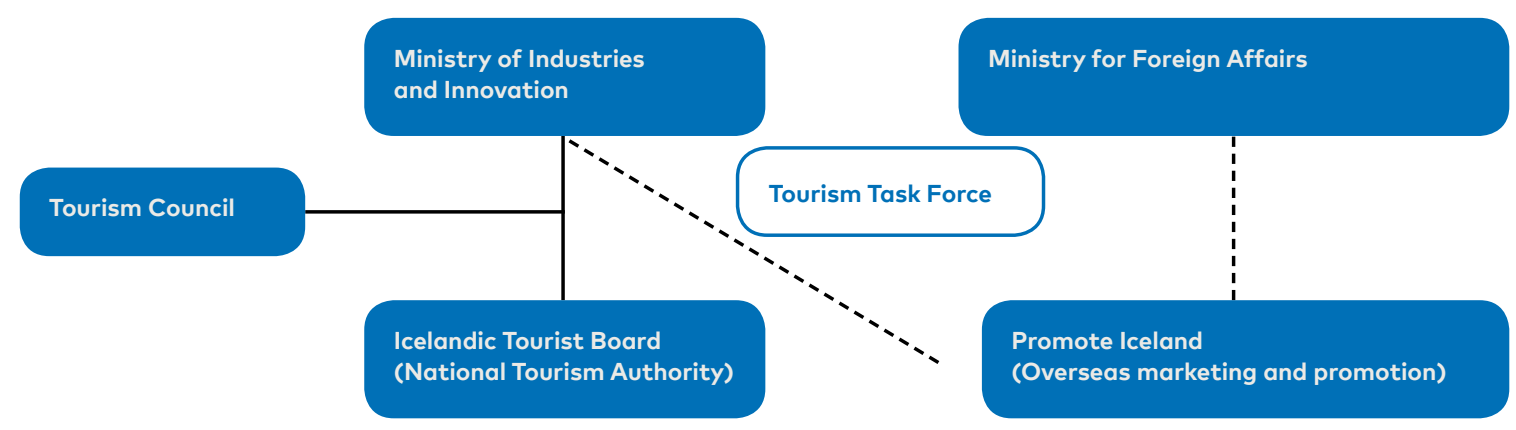

Source: OECD, adapted from Ministry of Industries and Innovation, 2018

for Tourism, Innovation and Industries nominates one member and Confederation of Icelandic Enterprise nominates four board members. Visit Iceland is a part of Promote Iceland and is the official destination marketing office for Iceland and aims to attract visitors to the country inter alia under the official destination brand "Inspired by Iceland".

In 2015, a special Tourism Task Force was established on the basis of an agreement made between the government of Iceland, the Icelandic Travel Industry Association (SAF) and the Icelandic Association of Local Authorities to implement the projects set out in the Roadmap for Tourism in Iceland. The Task Force is a temporary body set up for five years, ending in 2020.

\section{Seven Regional Marketing Offices of Tourism are} operated around Iceland focusing on local marketing and destination development. These offices work for 800 tourism companies and 66 municipalities.

\section{Policies and Strategy:}

In 2011, Althingi, the Icelandic parliament, accepted a parliamentary resolution on a tourism strategy for 2011-2020, focusing on four main objectives:
1. To increase the profitability of the sector.

2. To engage in systematic development of tourist destinations, effective product development and promotion and advertising work so as to create the opportunity to lengthen the tourist season, reduce seasonal fluctuations and contribute to better distribution of tourists throughout the country.

3. To enhance quality, professionalism, safety and environment awareness in the tourism sector.

4. To define and maintain Iceland's uniqueness as a tourist destination, in part through effective analysis and research. ${ }^{14}$

Iceland has experienced an unprecedented growth in the tourism sector for several years, with arrivals growing annually on average by $24.4 \%$ since 2010 . This development, which exceeded all forecasts, has had a huge economic impact, while at the same time posing a number of challenges, especially to the country's infrastructure. As a result, sustainability in its widest form - economic, environmental and social - is the main policy driver in Icelandic tourism. 


\section{NORWAY ${ }^{15}$}

Norway
In 2016 , the value creation in tourism in Norway reached NOK 114 billion, or
$4.2 \%$ of total GDP.
In 2016 , around 162,400 people were employed in the tourism sector in
Norway, measured in full-time equivalents. This is a growth of 11,000 full-
time equivalents from 2011.
Domestic tourism dominates the tourism industry in Norway, with over
70\% of overnight stays.
Inbound tourism has, however, seen a considerable increase in the last
couple of years, including a $10 \%$ increase in 2016 alone.
Key inbound markets are Sweden, Germany and Denmark, but emerging
markets such as China have seen a sharp increase.

\section{Governance and Legislation:}

Within the Norwegian government, tourism is under the main responsibility of the Ministry of Trade, Industry and Fisheries. The ministry is in charge of developing and regulating several issues related to the tourism sector. However, the ministry cooperates closely with other ministries on policy areas such as:

- Agri- and food tourism with the Ministry of Agriculture and Food.

- Cultural tourism with the Ministry of Culture.

- Regional development with the Ministry of Local Government and Modernisation.

- Environmentally sustainable tourism with the Ministry of Climate and Environment.

- Transportation and digital infrastructure with the Ministry of Transport and Communication.
Innovation Norway is an agency owned and funded by the Ministry of Trade, Industry and Fisheries (51\%) and the county authorities (49\%) and serves as a policy instrument for both the national and regional governments for value-creating business development across Norway. It serves as the National Tourism Administration, is responsible for international branding and promotion of Norway as a tourist destination and works closely with the industry. It also provides destination management programmes, competence programmes and product development (grants and loans) and works closely with the industry.

\section{Policies and Strategy:}

In May 2017, the parliament approved a government report (White Paper) on Norwegian tourism, "Experience Norway - unique and adventurous", outlining the government's overall policy for the tourism industry and ways to strengthen the industry's long-term development.

\footnotetext{
${ }^{15}$ Sources:

1) OECD (2018). OECD Tourism Trends and Policies 2018. OECD Publishing.

2) Erhvervsministeriet. (2016) Turismestrategier for de nordiske lande. (Unpublished draft).

3) https://www.innovasjonnorge.no/globalassets/reiseliv/tourism-strategy-innovation-norway-2014-2020.pdf

4) https://www.regjeringen.no/no/dokumenter/meld.-st.-19-20162017/id2543824/sec1

5) www.innovasjonnorge.no/en/start-page

6) Innovation Norge. (2017). Towards Sustainable Travel and Tourism in Norway. A Roadmap.
} 


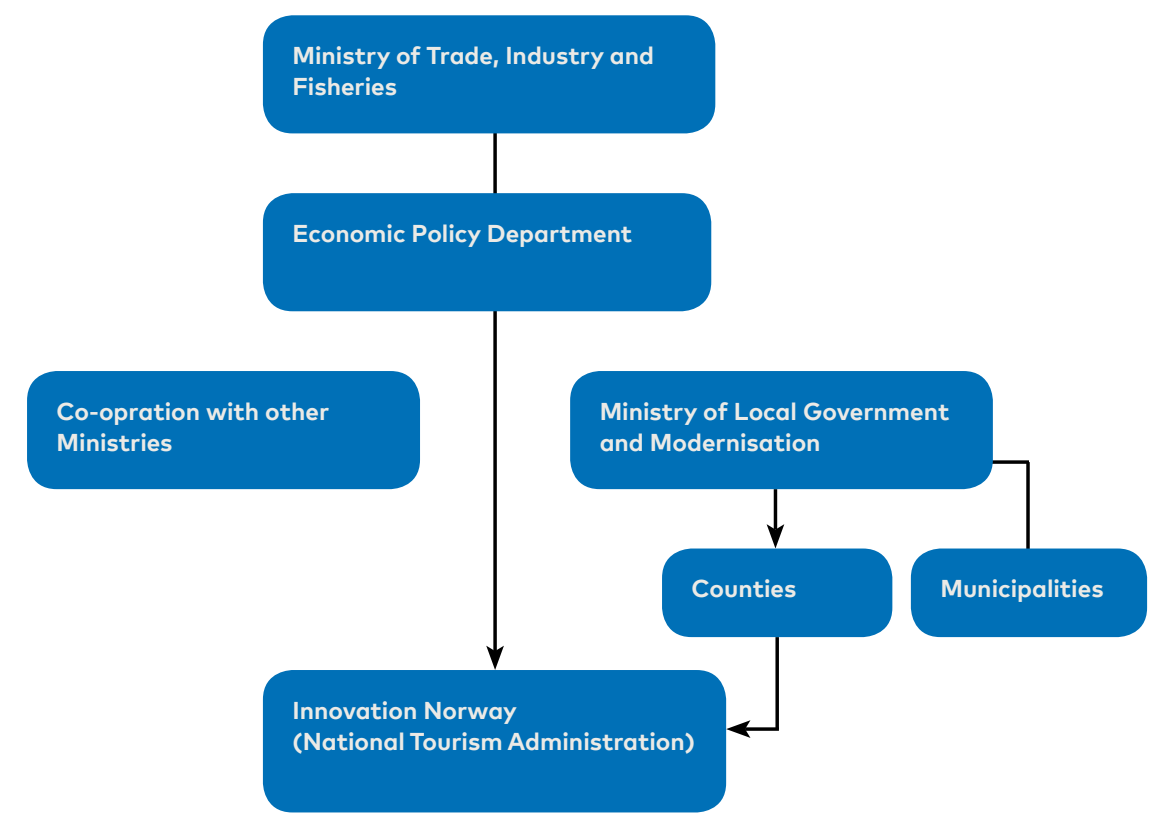

Source: OECD, adapted from Ministry of Trade, Industry and Fisheries, 2018

The main national policy priorities for developing the Norwegian tourism industry according to the report are:

- To establish sound framework conditions for business activity by lowering business tax, improving infrastructure and digitalisation of the public sector.

- To develop a sustainable tourism industry.

- To increase cooperation between stakeholders.

- To continue to promote Norway as a tourism destination.

- To increase knowledge and expertise in the tourism industry.

Great emphasis is put on sustainability in Norwegian tourism policy, and as a follow up to the White Paper, a number of stakeholders in the tourism industry published in 2017 a roadmap "Towards Sustainable Travel and Tourism in Norway". The roadmap is intended to serve three purposes:
- To provide a vision for moving towards sustainable travel and tourism by 2050.

- To serve as an input to the governmental green competitiveness strategy.

- To give recommendations to Norwegian tourism enterprises with key short- and long-term choices that need to be made in order to move towards a sustainable society by 2050 .

\section{Challenges:}

According to the OECD Tourism Report 2018, "One of the key challenges facing the Norwegian tourism industry are its relatively low level of value creation and profitability compared to that of other industries. This is due to factors such as the low share of high-value-added tourism products, a high level of seasonality and lack of co-operation both within the tourism industry itself and with other stakeholders involved in tourism. In certain parts of the country, overcrowding is a major issue". ${ }^{16}$ 


\section{SWEDEN ${ }^{17}$}

Sweden $\quad$ Tourism in Sweden has been growing steadily for the last ten years.
The tourism industry had a turnover of SEK 317 billion in 2017, which is
an increase of $7.4 \%$ compared to 2016.
The increase has mainly been driven by inbound tourism, which generated
a turnover of SEK 134 billion in 2017.
Compared to 2016 , the value of tourism exports increased by $11.4 \%$, while
total exports grew by $7 \%$.
In 2017 , the Swedish tourism industry accounted for $6.4 \%$ of the total
export value of Swedish goods and services, compared to $3.9 \%$ in 2000.
Tourism's share of the Swedish economy was $2.8 \%$ of GDP in 2017 and
has been rather constant, between $2.6 \%$ and $2.8 \%$ since 2000.

\section{Governance and Legislation:}

The Ministry of Enterprise and Innovation is responsible for issues relating to tourism.

The Swedish Agency for Economic and Regional Growth (Tillväxtverket) is a government agency under the Ministry of Enterprise and Innovation, responsible for matters related to tourism. The agency is responsible for official tourism statistics and information gathering on the development and economic effects of tourism. It is also responsible for promoting tourism initiatives and entrepreneurship, through national coordination and knowledge development, as well as through financing via the European Regional Fund and governmental funding.

Visit Sweden is a public-private partnership company owned by the government and the tourism industry in Sweden. The industry is represented by Svensk Turism AB, which is comprised of 170 companies and organisations from the tourism sector. Visit Sweden is responsible for international branding and promotion of Sweden as a destination and has offices in several countries.
The Council for the Promotion of Sweden Abroad is a forum for dialogue, consultation and cooperation on effective and long-term promotion of Sweden. Members of the Council are from the Ministry for Foreign Affairs, the Ministry of Enterprise and Innovation, the Ministry of Culture, the Swedish Institute, Business Sweden and Visit Sweden.

In addition to the national actors, there are tourism agencies at regional and local levels, which usually have the overall responsibility for tourism marketing and product development at the local level. The Swedish Association of Local Authorities and Regions (SALAR) is an umbrella organisation for local and regional authorities that has greatly increased its tourism activity in the recent years through partnerships with industry organisations and governmental agencies.

In 2016, the Minister of Enterprise and Innovation established a forum to bring together public and private stakeholders in the tourism sector with the aim of identifying common challenges and make a positive contribution to the development of the tourism industry.

\footnotetext{
${ }^{17}$ Sources:

1) OECD (2018). OECD Tourism Trends and Policies 2018. OECD Publishing.

2) Erhvervsministeriet. (2016) Turismestrategier for de nordiske lande. (Unpublished draft).

3) https://tillvaxtverket.se/download/18.59ff66f1157d260336b52dOc/1477920508755/Tourism\%2Oin\%20Sweden\%202015.pdf

4) https://www.regeringen.se/49bbc4/contentassets/b1cadc3d48b34366957aa75aadb39423/en-politik-for-en-langsiktigt-konkurrenskraftig-svensk-turistnar-

ing-prop.-20040556
} 


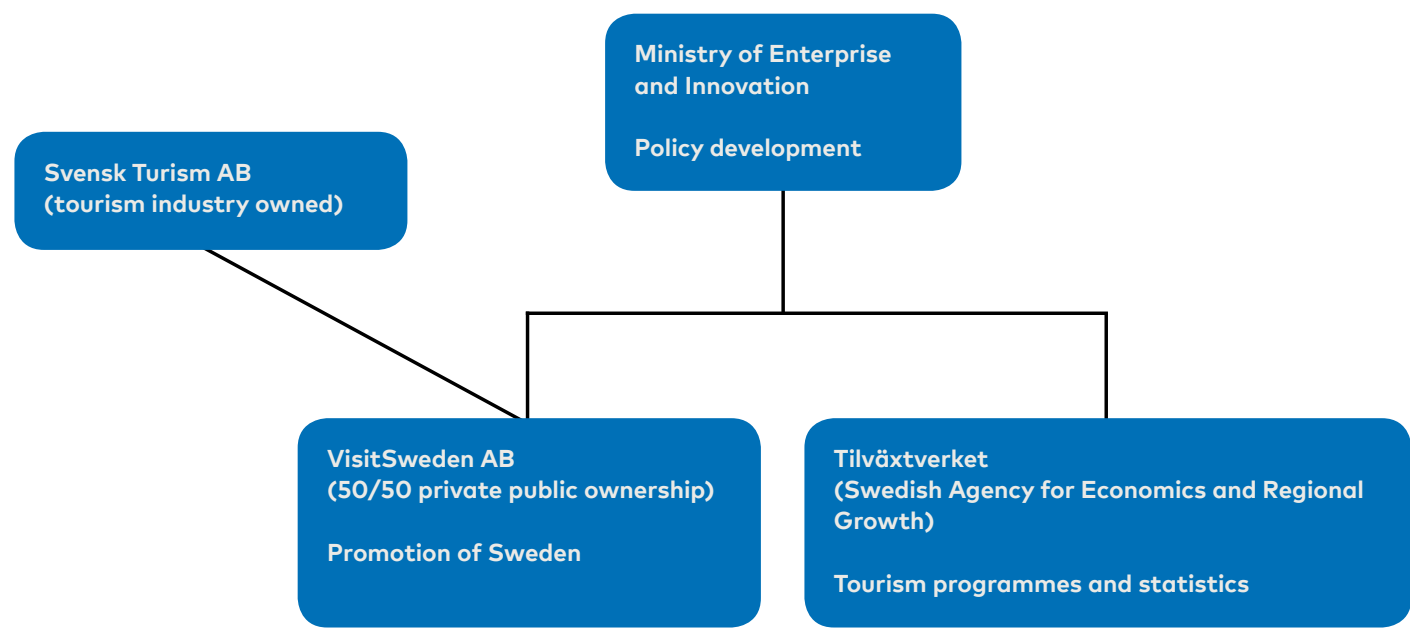

Source: OECD, adapted from Ministry of Enterprise and Innovation, 2018

\section{Policies and Strategy:}

The current Swedish national tourism

organisational structure was determined by an Act of Parliament in 2005, where the aim of the policy is that Sweden should be a highly attractive tourist destination with a competitive tourism industry in the long term, contributing to sustainable growth and increased employment throughout the country.

In November 2016, the government initiated a public consultation on a new cross-sector coherent national policy for tourism, Ett land att besöka - A country to visit. New structures are proposed and actions that are intended to contribute to internationally competitive tourism, sustainable growth, profitable entrepreneurship and employment across the country. The report was out on referral until April 2018 to around 250 key actors and stakeholders in the tourism sector from all over the country. Due to parliamentary elections in Sweden in September 2018, this process has been delayed.

\section{Challenges:}

According to the OECD Tourism report for 2018, the major challenges facing Swedish tourism include skills, connectivity and transport profitability, destination and product development, seasonality and sustainability. These issues are all addressed in the aforementioned new national tourism policy, Ett land att besöka, and actions and proposals put forth. ${ }^{18}$ 


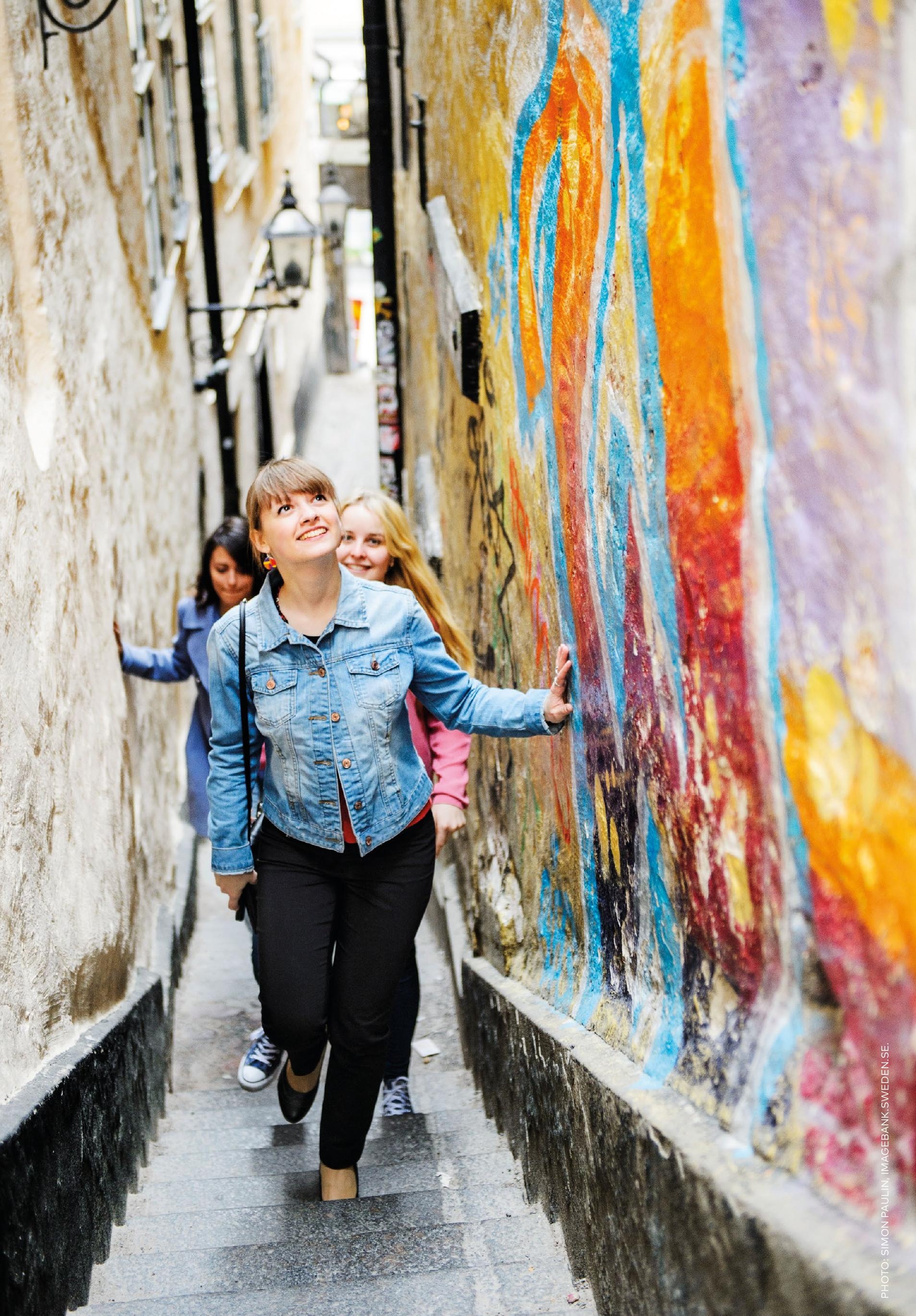




\section{ÅLAND ISLANDS}

$\begin{array}{lll}\text { Aland } & \text { - Tourism total share of GDP was } 27 \% \text { in } 2015 . \\ \text { Islands }^{19} & \text { - } & \text { Export value of tourism in } 2015 \text { was EUR } 294 \text { million, making it the largest } \\ \text { export sector in Åland. } \\ \text { - Every fifth job in the private sector in } 2015 \text { is in tourism. } \\ \text { - The number of incoming visitors increased by } 2 \% \text { between } 2014-2015 . \\ \text { - Total overnight visitors in hotels and cabins increased by } 7 \% \text { between } 2014- \\ 2015, \text { but cruise ship and camping overnights decreased. }\end{array}$

\section{Governance and Legislation:}

Tourism in Åland falls under the responsibility of the Ministry of Industry, Trade and Environment.

Legislation on tourism in Åland stems both from Åland local legislation as well as Finnish laws and regulations. Finnish legislation that affects the Åland tourism sector includes tax policies and labour laws.

Visit Åland is a public-private forum responsible for branding and marketing of tourism in Åland, as well as for product development. It is the official tourism organisation and works with the local tourist industry and its 340 members to develop tourism in Åland. As outlined on Visit Åland's website, ${ }^{20}$ its aims and tasks include to:

- Market and brand Åland as a travel destination.

- Represent the tourist sector to the authorities.

- Maintain tourist information and data.

- Encourage product development and increase quality in tourism by its member companies.

- Produce and distribute brochures and promotional material.

- Manage Åland's official tourism portal Visitaland.com
- Oversee press relations, trade fairs and other sales activities.

- Cooperate with retailers and agents.

- Manage advertising campaigns and other marketing and PR activities.

\section{Policies and Strategy:21}

The government of Åland has declared that tourism should be one of the base industries in Aland. The tourism in Åland relies on the cruise ship industry, and the focus is on how to increase the number of visitors that stop over in the islands. Aland has an exemption from EU regulations and is duty free.

\section{In 2012, a Tourism Strategy for Åland 2012-202222} was published by the government of Åland and Visit Åland. The strategy was written by a sixteenmember steering committee with representatives from both the public and private sectors, following a broad public consultation in which over 400 Ålanders participated.

The strategy defines both Åland's tourism vision, that "Åland is a kind, welcoming and resourceful island state that evokes a longing to visit", and the profile it wants to emphasise, namely that "Åland is the accessible island in the Baltic Sea

\footnotetext{
${ }^{19}$ http://www.visitaland.org/wp-content/uploads/sites/3/2015/11/Rapport-Turismens-på-Åland-2016.pdf ${ }^{20}$ http://www.visitaland.org/visit-aland-in-english/

${ }^{21}$ Sources:

1) Interviews in Åland in June 2018. (Camilla Gunel and Teresa Flojt).

2) https://www.researchgate.net/publication/306498584_Gauging_the_importance_of_tourism_in_Aland

22 http://www.visitaland.org/wp-content/uploads/sites/3/2013/09/turismstrategi-2012.pdf
} 


\section{Åland: Tourism Organisational Structure}

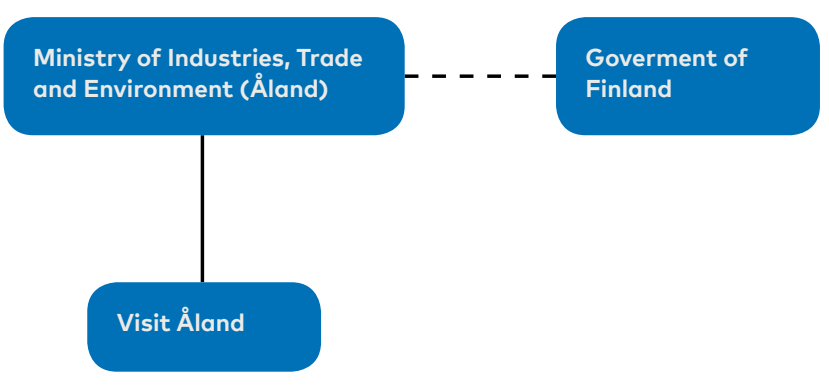

with an attractive maritime archipelago". The strategy is detailed and outlines well the emphasis and challenges facing tourism in Åland: product development, competence building, digitalisation, quality issues, sustainability and marketing.

The strategic plan is a document that will live for ten years. It does not contain concrete activities and projects; instead these will concretise in annual action plans and development plans. The plan will be revised and updated as needed during the period of 2012-2022.

\section{Challenges:}

Seasonality is one of the main challenges in the tourism industry in Åland, with the relatively short summer season being the main season for foreign visitors. Lack of hotel capacity is also a challenge. There is a need for increased professionalism in the sector and for it to modernise and digitalise its services. The industry has been run on a part-time basis due to the high seasonality.

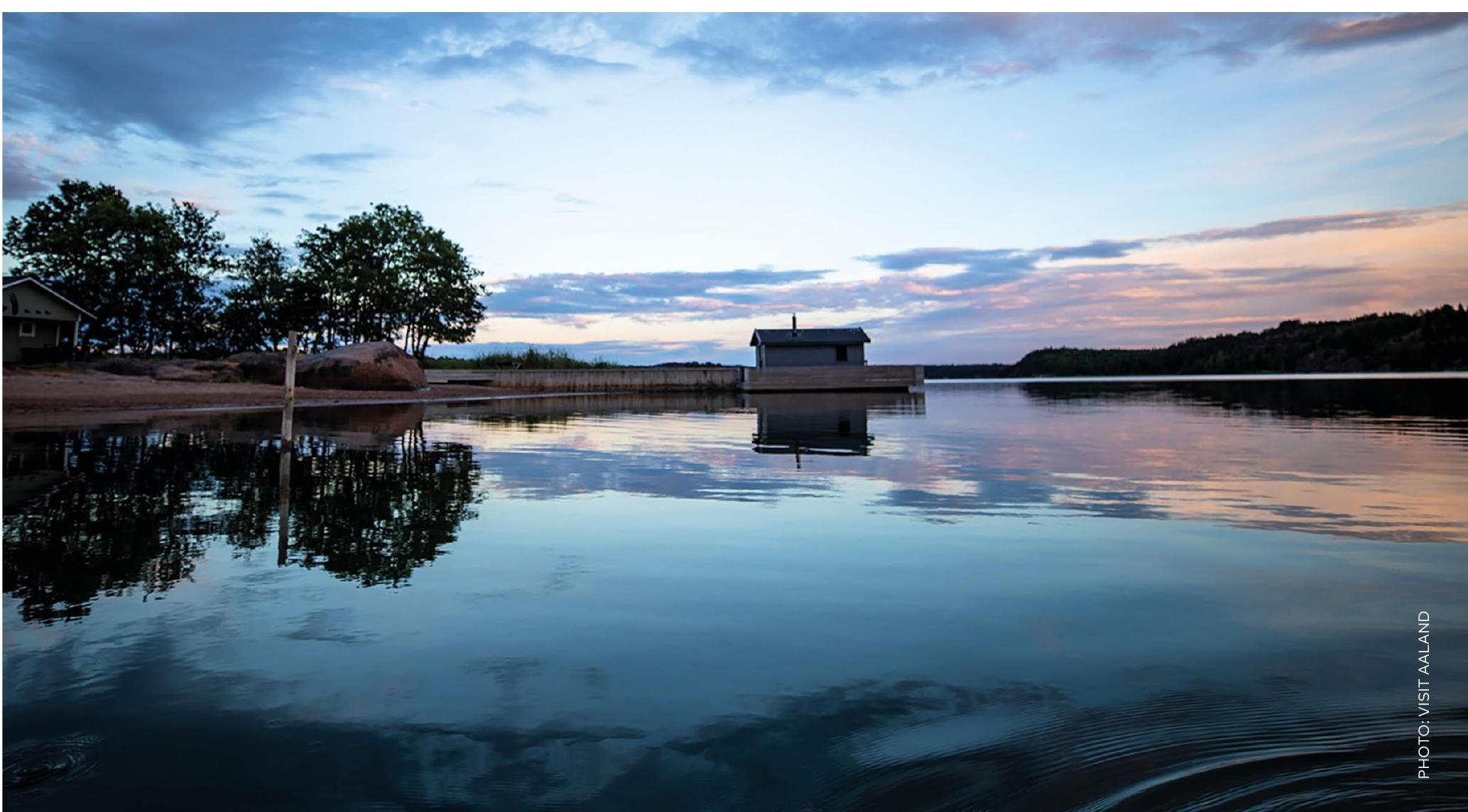




\section{FAROE ISLANDS ${ }^{23}$}

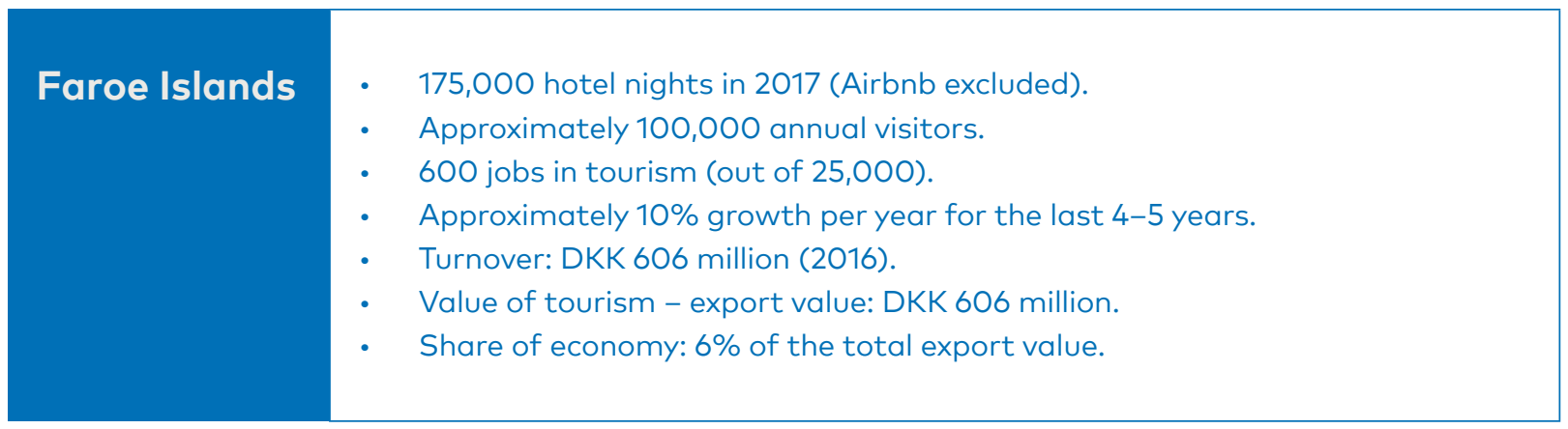

\section{Governance and Legislation:}

Tourism falls under the responsibility of the Ministry of Foreign Affairs and Trade.

The ministry cooperates with other ministries on tourism issues, such as with the Ministry of Culture and Ministry of the Environment.

The tourism sector in the Faroe Islands is also regulated by Danish rules and legislation, for example regarding transportation and aviation.

Visit Faroe Islands Tourist Board was established in 2010 and is responsible for tourism development and the promotion of the Faroe Islands as a tourist destination. Visit Faroe Island is a Ltd. company, fully owned by the state.

At the recommendation of a cross-sector working group, a new development department was set up with the main task of better organising the internal tourism industry. The new department is an integrated part of Visit Faroe Islands.
Regional tourist offices in the municipalities are responsible for local tourism development and regional marketing. The new development department is intended to work with local authorities to develop local products.

\section{Policies and Strategy:}

A new tourism strategy was formed in the Faroe Islands in 2017 by a working group with members from the tourism industry, municipalities, tourism information offices, nature conservation and government officials.

The main focus of the new strategy is to improve tourism infrastructure and the regulatory framework, while focusing on sustainability in the sector.

There is an ongoing discussion in the Faroe Islands on the establishment of a nature protection law, which would regulate the access to nature better. Due to the lack of such legislation, the government of the Faroe Islands is already in the process of 


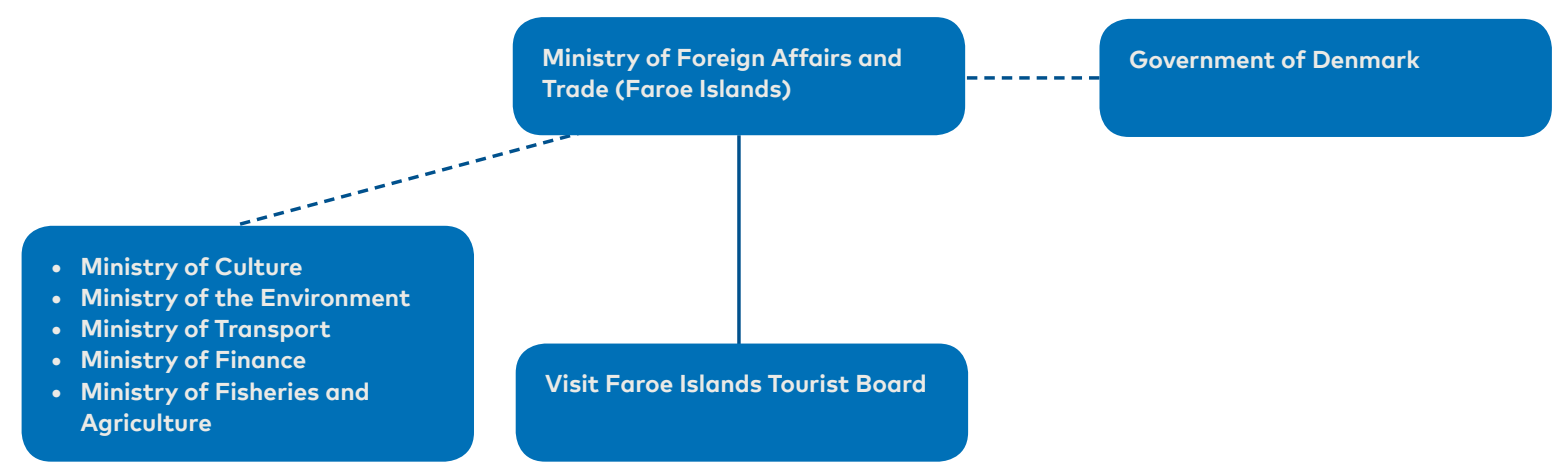

developing a new nature-protection law that would support nature-protection initiatives aiming at a more sustainable tourism industry.

Moreover, there is much ongoing discussion in the Faroe Islands about access to nature, regulations concerning payment for access, farmers and the public rights and duties in the nature, etc.

\section{Challenges:}

One of the biggest challenges for the tourism sector in the Faroe Islands is to decrease effects of seasonality and distribute the visitors more around the country by widely improving infrastructure, especially in terms of hotels and services. There is great focus on sustainability and the balance of how to brand and promote the Faroe Island more actively and attract more visitors without risking overcrowding.

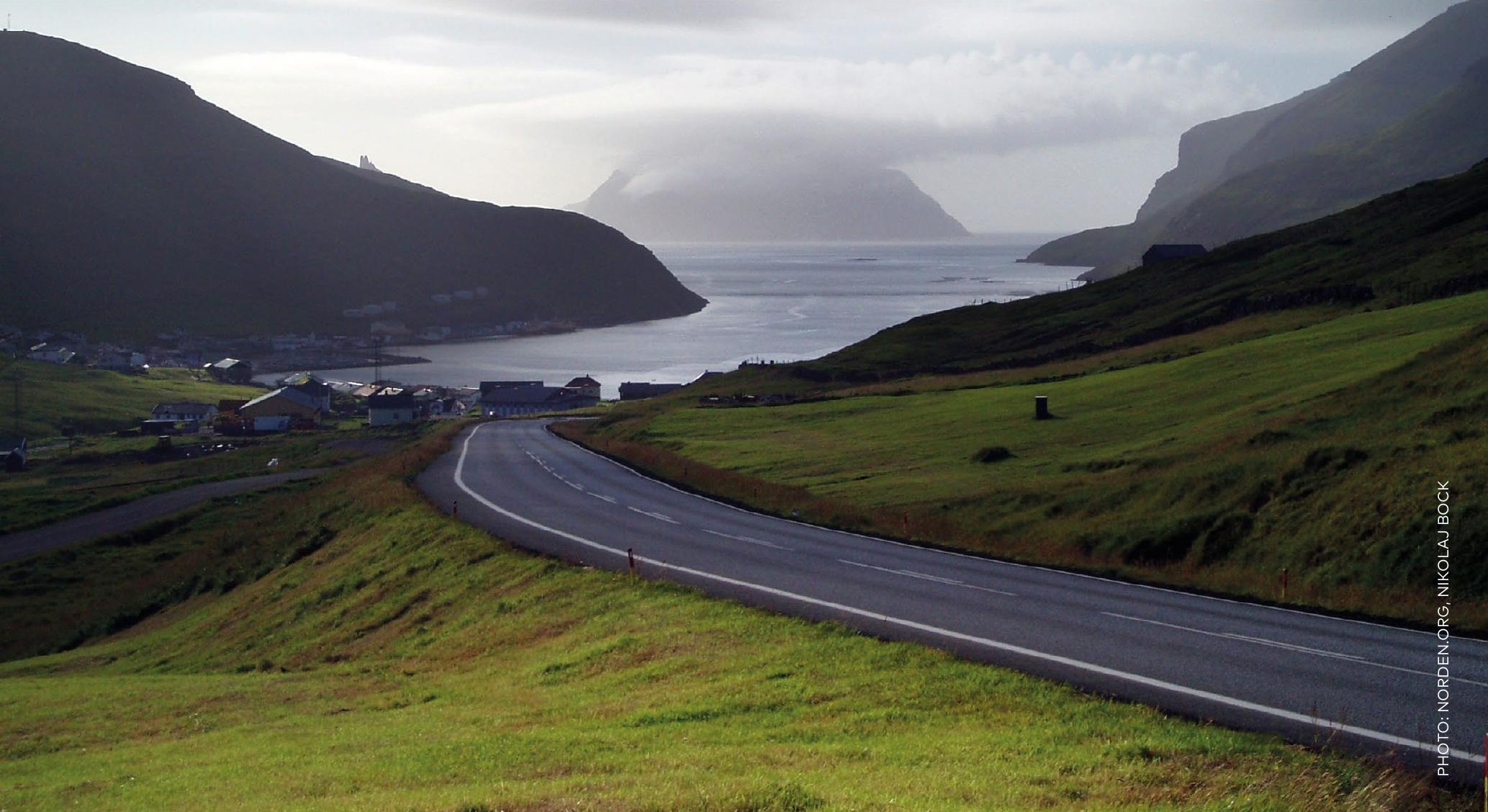




\section{GREENLAND ${ }^{24}$}

\begin{tabular}{|c|c|}
\hline Greenland $^{25}$ & $\begin{array}{l}\text { - } \quad \text { Number of visitors in } 2017 \text { approximately } 85,000 \text {. } \\
\text { - } \quad \text { Gocio-economic turnover of tourism in } 2017 \text { approximately DKK } 500 \text { million. } \\
\text { - } \quad \text { Value of tourism export value is estimated at DKK } 500 \text { million. } \\
\text { - } \quad \text { Tourism share of economy } 11.7 \% \text {. } \\
\text { - In } 2017 \text {, foreign tourists created } 759 \text { jobs as a result of direct and indirect } \\
\text { employment effects. }\end{array}$ \\
\hline
\end{tabular}

\section{Governance and Legislation:}

Tourism falls under the responsibility of the Ministry of Industry and Energy in the Greenland self-rule government.

The tourism sector in Greenland is also regulated by Danish rules and legislation, for example regarding transportation and aviation.

Visit Greenland is the national tourist board of Greenland and a government-owned agency responsible for tourism development in Greenland. The six-member Board of Directors is appointed by the government. Its vision is to create responsible growth with its partners through focus, shared knowledge and idea development.

Visit Greenland acts as an advisor to the government on matters related to tourism. The role of Visit Greenland is outlined as follows:

"The purpose of the company is to serve as the national tourism resource centre of Greenland, to work to brand and promote Greenland as a tourist destination and to work to promote and develop the tourism industry and tourism activities in Greenland". 26

\section{Policies and Strategy: ${ }^{27}$}

In 2016, Visit Greenland published a tourism strategy for the period 2016-2019, based on developments and changes in the tourism sector, both domestically and internationally. The broad strategy is intended for all those who work both directly and indirectly with tourism, including tour operators, municipalities, administrations and educational institutions.

Visit Greenland's 10-year vision for tourism in Greenland is:

"By 2025, the tourism industry of Greenland is one of the leading industries of the country, and Greenland is an internationally known and sought after adventure and cruise destination. The Greenlandic tourism industry is known for its innovative profile, unique Arctic experiences and a tourism development focused on sustainability, responsibility and a local foundation".28

For Visit Greenland, responsible tourism means:

- Involving local people in tourism development to generate economic benefits for the local communities.

\footnotetext{
${ }^{24}$ http://corporate.greenland.com/en/about-visit-greenland/

${ }^{25}$ www.stat.gl

${ }^{26} \mathrm{http}: / /$ corporate.greenland.com/media/8043/turismestrategi_eng_light_senest.pdf

$27 \mathrm{http} / / /$ corporate.greenland.com/media/8043/turismestrategi_eng_light_senest.pdf

${ }^{28}$ Visit Greenland. (2017). Tourism Strategy 2016-2019, 23.
} 


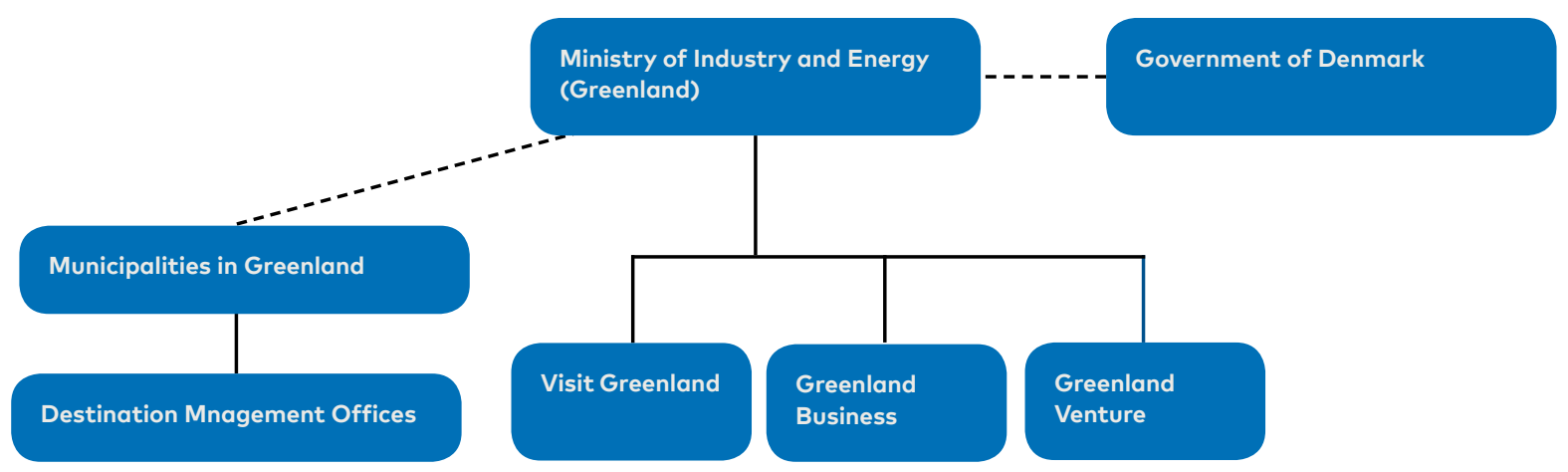

- Contributing positively to the conservation of natural and cultural heritage.

- Minimising negative environmental and social impacts.

- Offering experiences that create more meaningful relationships with locals, thus providing a greater understanding of local cultural as well as social and environmental challenges.

- Creating commercial cooperation areas between local tourism actors and foreign travel agencies that target the tourism segments that are relevant to Greenland.

Visit Greenland's five key focus areas of action are market development, visibility, season expansion, accessibility and framework conditions, as well as statistics and documentation. Each area is worked through a project-based approach by collaborating with stakeholders regionally, nationally and internationally, thereby creating synergy, coownership and co-financing. This strategic approach is also a result of the company's size and the need to optimise human resources.

High emphasis is laid on sustainability, environmental protection and digitalisation. Increased traffic on well-updated official Internet sites, such as www.greenland.com and www.corporate.visitgreenland.com, demonstrates both the huge increase in the interest of Greenland as a tourist destination and the importance of digitalisation for the visibility of Greenland.

\section{Challenges:}

Lack of sufficient infrastructure is one of the most important challenges facing tourism in Greenland, both when it comes to transportation and connectivity as well as in the need for added hotel and accommodation options. The challenges are being tackled with a new airport infrastructure plan, the future constructions of more accommodation as well as the training and certification of local operators. Seasonality is also a challenge with the high season, summer, still being very short, which has prevented the industry from becoming a full-year employer. Visit Greenland's strategy, therefore, focuses on the following five areas, which the tourist board continuously works on to progress:

- Market development

- Visibility

- Seasonality

- Accessibility and framework

- Statistics and documentation 
The Big Picture

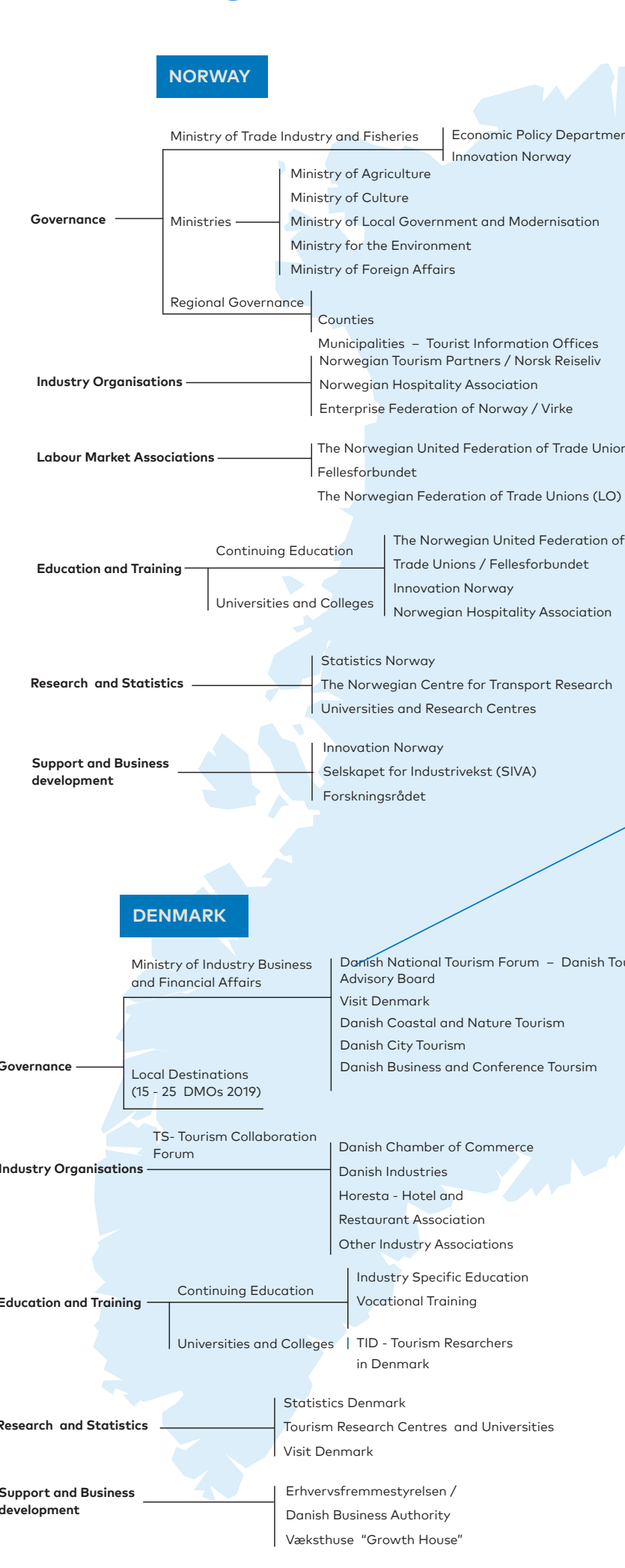

Note: This chart is by no means exhaustive and is published to provide an overview of organisation

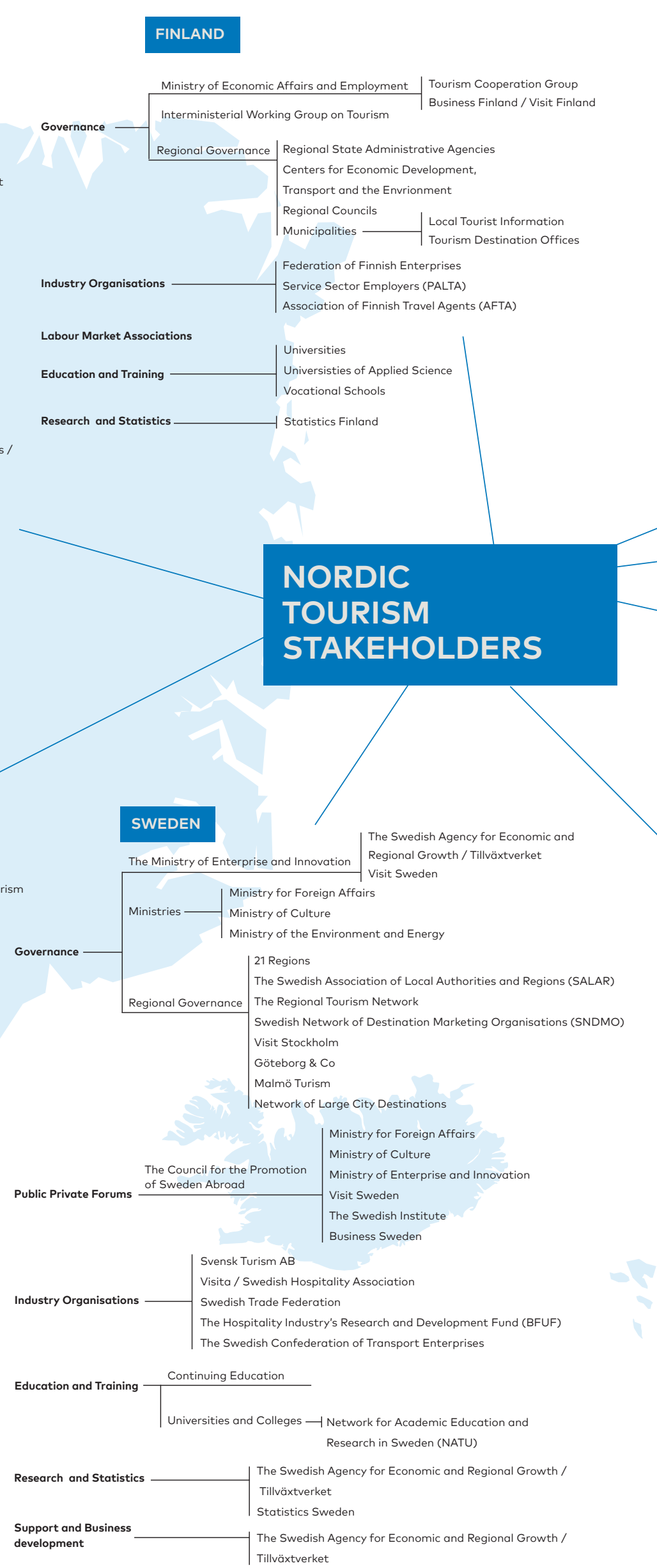

ÅLAND

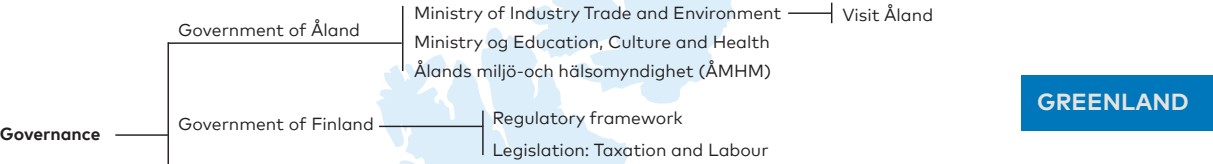

Legistation: Toxation and Labour Âlands Näringsiv
Visit Âland - Tourism Information Office Virtagamapa hlond ing Vocational School

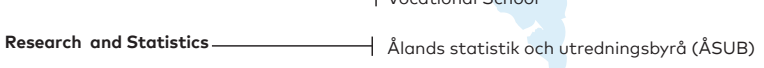

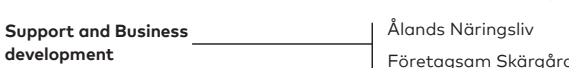

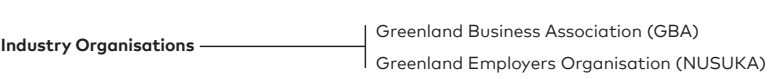

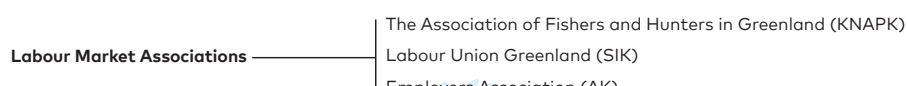
Iilimatusarfik (University of Greenland)

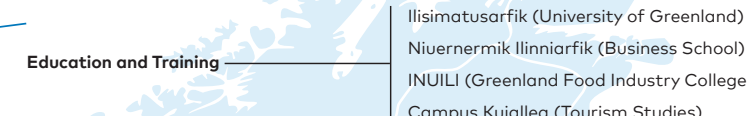
\begin{tabular}{l|l} 
Research and Statistics & Statistics Greenland \\
visit Greenland
\end{tabular}

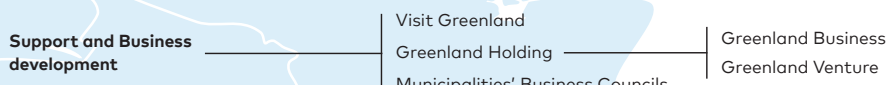
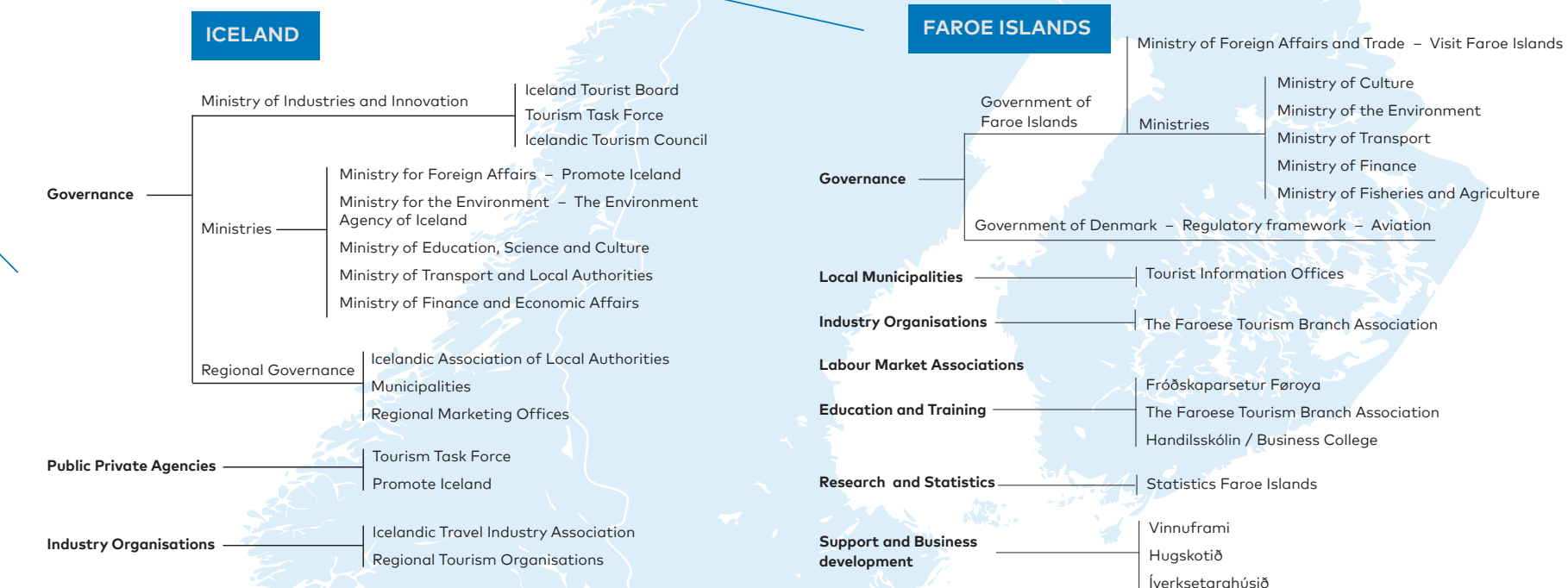
Industry orgonisations -

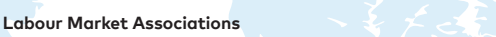

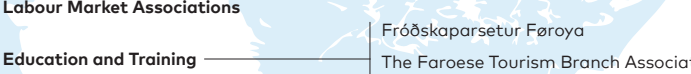
Research and Statistitis - S Statisitics Fare Istonds

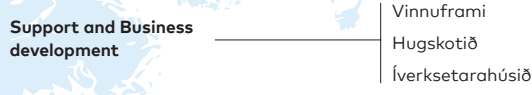




\title{
Nordic Organisational Structures and Tourism Policies
}

\author{
A Few Observations
}

After reviewing organisational structures and tourism policies in all of the Nordic countries, a few observations are worth noting. Despite different national organisational structures and regulatory environment for tourism, there are notable similarities in the way that the Nordic countries have organised their tourism sectors which are interesting to highlight for the benefit of this analysis.

All the Nordic countries emphasise, to a varying degree some sort of a "whole of government" or cross-sectoral structure with the aim to best be able to facilitate cooperation and streamline the framework relating to the tourism sector in each country.

The tourism sector is different from other more traditional industries in the way that it cuts through many different sectors, including transportation (aviation, shipping, bus transport, etc.), hospitality industry (hotels, restaurants etc.), food production (agriculture, fisheries industry, food and beverage producers) and cultural sectors (museums, music, film, etc.). Moreover, these sectors fall under the responsibility of several ministries and regional government actors, making it impossible for any one government actor, be it national or regional, to have full control, oversight or responsibility of the tourism sector as a whole.

Cooperation and consultation between all of these actors is regarded as vital, and the development in all the countries has been towards establishing such structures, formally or informally:
- Denmark: The Danish National Tourism Forum and The Danish Tourism Advisory Board.

- $\quad$ Finland: The Inter-Ministerial Working Group on Tourism and the Tourism Cooperation Group (temporary from 2016-2018).

- Iceland: The Task Force on Tourism (temporary from 2015-2020) and the Icelandic Tourism Council.

- Norway: Cooperation between several ministries on tourism issues.

- Sweden: The Council for the Promotion of Sweden Abroad and the cross-sectoral work on the policy paper "Ett land att besöka".

It is also interesting to compare the content of national tourism policies with regard to the issues that are being prioritised. Almost all the countries emphasise the need to ensure sustainable development of the tourism industry, not only regarding environmental sustainability, but also in terms of social and economic sustainability.

There is much emphasis placed on the importance of reducing seasonality within the sector, which plays a vital role in regional development within the countries. Digitalisation is furthermore a common issue in all of the Nordic tourism policies and an issue which is also viewed as a potential solution in solving the challenges of reducing negative effects of seasonality and increasing the sustainability of the sector. 


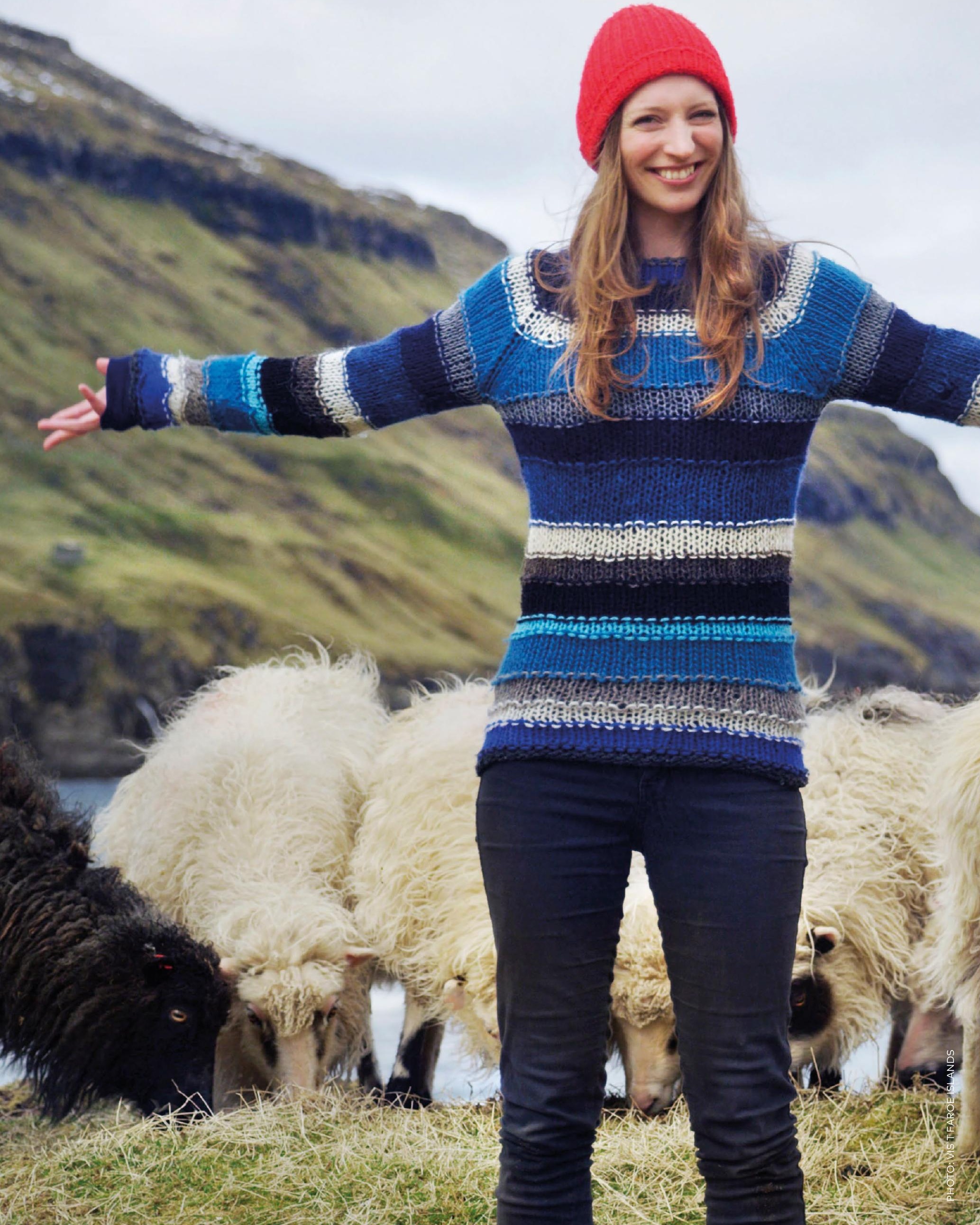




\section{COMMON THEMES AND FOCUS AREAS}

The main themes addressed in this analysis are in line with global trends and challenges and in line with the main concerns of key actors within the tourism sector in the Nordic countries. The main themes resonate strongly with key themes in national tourism strategies and national and Nordic business and innovation policies. While the Nordics do have different priorities in some respects regarding tourism, they share an overall agreement on the importance of these themes:

- Digitalisation and Smart Nordic Destinations

- Sustainable Development in Tourism

- Marketing Nordic Destinations

- Seasonality, Destinations and Competitiveness

\section{Digitalisation and Smart Nordic Destinations}

\author{
Digital Technology as a Driver for \\ Nordic Innovation \\ Digital technology has already transformed \\ businesses, customer behaviour, social interaction \\ and daily lives all over the world, and disruptive \\ digital technology is a key driver of tourism \\ innovation. This is evident in the emergence of new \\ business models based on digital technologies that \\ have, over a short period of time, become dominant \\ in global tourism. These include internationally \\ dominant companies such as Airbnb, Uber and \\ Booking.com but also countless other technology \\ and data-driven businesses capitalising on \\ opportunities within tourism.
}

Smart and innovative use of digital technology in tourism can strengthen economies and local innovative capabilities. Digital innovation can increase the value of customer experience and the value of products and services offered. Digitalisation can be an important tool to counteract seasonality. Use of social media through a variety of platforms and interactive services to reach new and niche markets will only grow in importance in the future. There are immense opportunities in using digital technology to increase safety and to control traffic and overcrowding. Digital technology can also play a crucial role in solving ecological challenges and in increasing sustainability.

There has already been extensive work on digitalisation strategies in several of the Nordic countries. To name a few, the Danish government has presented a digital growth strategy, the Swedish government has published a Digitalisation Strategy, and Finland has recently launched its strategy, "Finland's Age of Artificial Intelligence" which has the objective of turning Finland into a leading country in the application of artificial intelligence. In short, Nordic countries have set an ambitious agenda for digitalisation and aim to be global leaders. The Nordics are already at the forefront of innovation in digital technology in many areas. 


\begin{abstract}
A DIGITAL DIVIDE?
A number of studies have highlighted the digital divide that seems to exist between tourists and local tourism companies. In short, these small enterprises do not seem to have the digital capabilities necessary to reach their most desirable target group: the enlightened, or "high-yield / low impact" tourist. A study on Icelandic tourism and technology from 2016 demonstrated that in Icelandic tourism, a digital divide does indeed exist and many enterprises miss the opportunities and revenue offered by the digital economy.
\end{abstract}

Nordic collaboration with the aim of facilitating further digital innovation, not least through publicprivate partnerships could unleash opportunities for innovation in a range of fields within tourism. There is a lot of anticipation associated with digitalisation. However, while there is huge potential in digital technologies such as data mining and mobile data tracking, there are also important technical and legislative hurdles preventing the full realisation of the potential of digitalisation.

In order for Nordic tourism to realise the growth promised by new technologies, the Nordic governments could cooperate and set common objectives. Work in this field should put emphasis on cross-border collaboration. This includes aligning regulations and implementing policies that encourage greater information and data sharing.

This work could prove to be quite complex, and there must be a clear political mandate and a strong focus to support this. Wide ranging cooperation is necessary, not least between the public and private sectors throughout the Nordic region.

\section{Focus on Digitalisation}

Digital competence is an integral part of all main themes identified by experts within the tourism industry as key to ensuring competitiveness and sustainability within Nordic tourism. These reoccurring themes are interlinked in a variety of ways, but a key to them all is digitalisation. Digitalisation is and will continue to be a game changer in Nordic tourism. This is also clear from the dialogue with representatives from the industry, who place digitalisation high on the agenda of Nordic collaboration. The focus within the Nordic tourism industry is more on the opportunities of digitalisation than the challenges.

In their meeting in Stockholm in May 2018, the Nordic Business Ministers decided that digitalisation should be a key focus for Nordic tourism collaboration over the coming years. The ministers also asked Nordic organisations to formulate a concrete proposal on how best to collect and use statistical data from Nordic tourism across borders, for example using digital data sources. This project is in its initial stages under the leadership of the Swedish Agency for Economic and Regional Growth (Tilväxtverket).

Collaboration in this field can potentially create value for the sector in a range of areas and open up new opportunities. The constant and abrupt changes in digital technology make it difficult to predict what the next radical changes will be. It is all the more important that there is ability and awareness within Nordic tourism to strengthen digital competence throughout the sector in order to be able to take advantage of new opportunities. By the same token, the price of falling behind on mastering and implementing digital technology could be high. It is extremely important for individual companies and the sector to stay ahead of the game.

\section{Challenges on the Way to Digitalisation}

Digital competence will be necessary for all types of tourism businesses if they want to stay competitive. 
It is a necessary part of new business models, effective marketing and customer relations, service delivery, experience development, quality and security, etc. The smaller, less innovative tourism SMEs must at the very least be able to be a part of the game by being able to exploit existing technologies. There is still a large proportion of the industry which is not up to speed when it comes to digitalisation and there is a lack of competence on how to tackle the challenges of digitalisation with real and tangible solutions.

Digitalisation also poses challenges to governments and the public sector. The lack of competence evident in the tourism industry is also evident among policy makers and in the public sector, which as a result becomes reactive rather than proactive. There is an awareness of the challenges, but they are not being dealt with effectively.

While global players such as airlines and booking platforms have revolutionised the tourism industry and opened up new possibilities for small businesses to access customers, digital disruption has also resulted in a growing divide between SMEs and those who control the digital platforms. As many SMEs have not been able to keep up with rapid technological and market changes, the growing digital divide has developed between the big players and smaller regional SMEs in particular. This divide can also occur between SMEs and customers. If there is an imbalance between the digital competence of customers and the competence in the SME, the customers will turn to intermediaries, such as booking platforms, to conclude their business and the SME might lose potential income. $^{29}$
SMEs have everything to gain from improving digital competence. Digital solutions can increase growth and productivity, improve customer service, make more efficient use of human resources, improve the visibility of the company and its products and services. It is also important for SMEs to use social media effectively to communicate directly to their customers both before and after their visit and thereby gain better control of their marketing, image and service delivery.

\section{Smart Nordic Destinations}

The core of the Smart Destinations idea is to facilitate innovation by using digital technology strategically to create innovative and tailor-made services and products, while at the same time strengthening local foundations such as business competitiveness, resource management, ecological and social sustainability and the quality of life of residents. ${ }^{30}$ The concept of Smart Destinations can be regarded as destination management in a digital era.

The concept of Smart Destinations has been developed extensively in Spain, where it has become a central theme of government tourism policy and has been implemented as a strategy for economic growth in a number of regions. The Spanish Smart Destination policy is essentially an innovation policy, acknowledging that "innovation is necessary in all areas of society". ${ }^{31}$ The present and future economic importance of tourism lies at the roots of the urgency behind the Spanish Smart Destinations strategy:

"In this sense, the digital sphere allows us to promote destinations, products and services, as well as, at the same time, getting to know our client

\footnotetext{
${ }^{29}$ Kristjánsdóttir, S., (2016). Tourism and Technology; Does digital capacity of tourism impact the sustainability of Icelandic tourism?

${ }^{30}$ Smart Destinations Report: building the future. (2015). Ministry for Industry, Energy and Tourism, Spain.

${ }^{31}$ Smart Destinations Report: building the future. (2015). Ministry for Industry, Energy and Tourism, Spain. 5

${ }^{32}$ Smart Destinations Report: building the future. (2015). Ministry for Industry, Energy and Tourism, Spain. 15
} 
and adapting to him as never before. It allows us to offer more personalised, higher quality products and services" ... "From this point of view, ICT has opened up a new horizon in the tourism industry which poses challenges and opportunities simultaneously and which requires great effort to adapt to on the part of both the companies providing these services as well as the tourist authorities". ${ }^{32}$

The challenges identified in Spanish tourism apply in many ways to the challenges faced by the sector in Nordic regions. In order for Nordic tourism to develop into Smart Tourism, a lot of work will have to take place with and in companies at the regional and local levels. A framework, building on the experiences from countries like Spain, would be needed in order to facilitate the transformation of Nordic tourism into Smart Tourism: a knowledge industry regenerated by innovation, technology and sustainability.

\section{Recommendations:}

- In order for Nordic tourism to realise the growth promised by new technologies, Nordic ministers are encouraged continue to prioritise digital development and technological innovation in tourism. Strong political mandate is needed to facilitate the necessary alignment of regulations, cross border collaboration and implementation of policies that encourage greater information and data sharing.

- In order to facilitate a more rapid digital development in Nordic tourism, the initiative should be taken to pool resources and build on the extensive work which has already been carried out on digitalisation policies in the different Nordic countries.
- A forum for new and disruptive ideas within digital tourism with a focus on smart destinations, smart mobility and connectivity should be created. This is an opportunity to draw on the experience, expertise and work of key actors within the tourism sector, such as PALTA in Finland, Dansk Industri and others.

- Drawing on international experience, a Nordic network and action plan for Smart Destinations should be established. The objective of the network would be to develop guidelines for regional and local authorities, tourist companies and SMEs on how to become a smart destination, building on digital means and destination development.

- A Nordic collaborative project on tourism statistics and mobile data has already been proposed by the Swedish Agency for Economic and Regional Growth, in collaboration with Innovation Norway. The project is an important first step and further cooperation should be supported.

- Best practice cases of smart and effective uses of digital technology from destinations and tourism businesses should be collected, in order to facilitate knowledge transfer. This can provide an assessment of key competences and actions which have the potential to strengthen digital competence in Nordic SMEs and destinations.

- A Nordic network focusing on Traveltech should be established. This network could become a platform through which to identify and activate collaboration between public and private actors, technology developers and investors. 


\section{Sustainable Development in Tourism}

\author{
Sustainability - The Key to Nordic Tourism \\ Sustainability is a central issue in Nordic tourism \\ as well as in almost all national tourism policies \\ in the Nordic countries, and a topic which has a \\ variety of implications for the industry. Sustainable \\ development in its broadest form has real \\ implications for the viability of environmental, \\ social and economic renewal of the tourism sector \\ in the Nordics. Cultural sustainability is also an \\ important issue for regions and communities in \\ the Nordics. Environmental integrity and natural \\ environment are increasingly seen as assets for the \\ attractiveness of destinations, regional branding \\ and the overall economic viability of communities \\ and regions. ${ }^{33}$
}

There is growing awareness of the fragile relationship between tourism and sustainability among the general public in the Nordic countries as well as in the political sphere. The exception might be Denmark, where the sustainability discussion has focused more on negative social impacts of tourism in selected popular areas in Copenhagen.

These pressures are on the increase, and politicians, policy makers and the tourism industry must be prepared to answer decisively. Future growth and development within Nordic tourism relies on the countries being able to safeguard the environment and nature, as well as their culture and way of life. There is an obvious relationship between the value of the resource and its preservation and sustainability. This value is of crucial importance when it comes to developing and marketing Nordic destinations as well as for the profitability of tourism businesses. This corresponds with the shared understanding in the Nordic tourism sector that the Nordics should aspire to direct their marketing to selected "high yield - low impact" groups and sway away from overcrowding and mass tourism.

All the Nordics share a position as being a destination for unspoilt nature experiences. However, all the Nordic countries have to some extent experienced overcrowding, environmental damage and strain on public services and infrastructure.

Developing and implementing tools to monitor the impact of tourism by tracking the impact it has at various levels, is an important requirement for more effective tourism policy development and destination management in the Nordics. Such instruments are under development and implementation in some of the Nordic countries. Examples include an ambitious project initiated by the Icelandic Ministry for Industries and Innovation and led by the Icelandic Tourism Task Force on developing impact indicators for Icelandic tourism ${ }^{34}$ and the development of the Sustainable Destination Standard led by Innovation Norway. ${ }^{35}$ Better tools will provide a stronger base for prioritising resources and actions to strengthen the tourism industry in the Nordic countries as a whole.

To varying degrees, depending on different markets, there is a real perception of a Nordic brand. The Nordic countries are perceived as countries which emphasise and value sustainability. There is a real and growing demand for authentic nature experiences which have become an increasingly scarce resource in other parts of the world. With increasing urbanisation and environmental

\footnotetext{
${ }^{33}$ Øian, H., Fredman, P., Sandell, K., Sæpórsdóttir, A.D., Tyrväinen, L., and Søndergaard Jensen, F. (2018) Tourism, nature and sustainability. A review of Policy Instruments in the Nordic countries. Nordic Council of Ministers. TemaNord 2018:534

${ }^{34} \mathrm{https} / / /$ www.stjornstodin.is/calendar-event/alagsmat-throun-alagsvisa-1-afangi

${ }^{35}$ https://www.gstcouncil.org/innovation-norway-sustainable-destination-standard-is-now-a-gstc-recognized-standard/
} 
pressures, the value of nature experiences in Nordic destinations will only increase.

\section{The Politics of Sustainability}

As a rule, representatives from the tourism industry in all Nordic countries place high importance on sustainability. All agree that sustainability is a key theme for Nordic tourism today and a cornerstone for Nordic tourism development in the future. Sustainable development is high on the agenda of the Nordic Council and the Nordic Council of Ministers, and it is an issue which all the Nordic countries are committed to at the highest governmental level. All Nordic countries, except Denmark, emphasise sustainability in their national tourism policies, and all Nordic countries are committed to the Paris Agreement from 2015 and its targets on combating climate change. All the Nordic countries have incorporated the UN Sustainable Development Goals, Agenda 2030 into national policy objectives, and a common Nordic Strategy for Sustainable Development is in place until 2025. ${ }^{36}$

Tackling the many different facets of sustainability in tourism and achieving real results is a huge challenge with all sorts of touching points with other sectors, interests and governance. Despite great efforts to work towards sustainability and despite being among world leaders when it comes to being closest to achieving the UN Sustainable Development Goals by $2030,{ }^{37}$ the Nordics stand out as over consumers of natural resources and substantial producers of waste. ${ }^{38}$
The challenges of sustainability are real and complex, but it is worth keeping in mind that the potential contribution of tourism towards attaining sustainability goals and lowering carbon emissions are also enormous. The economic and cross-sectoral impact of tourism, the call for growth and the real growth which is currently taking place in the sector makes the importance of working towards sustainability even more critical. Sustainability implies a long-term perspective while at the same time presenting an urgency for immediate action to realise goals. Sustainability is a global and a local challenge which must be addressed through a variety of channels. Sustainable tourism calls for new and innovative solutions, both in terms of technical solutions to support environmental sustainability and the development of sustainable tourism experiences, products and services.

\section{The Nordic Council of Ministers' Agenda on Sustainability} Generation $2030^{39}$ is a key policy document and a declaration of commitment signed by the Ministers for Nordic Co-operation to implement the global UN 2030 Agenda in the Nordic Region. The declaration is obviously also in line with the Nordic Strategy for Sustainable Development.

"Sustainable Consumption and Production", an analysis of Nordic progress towards SDG12 is another important publication by the Nordic Council of Ministers. ${ }^{40}$ The intention of the analysis is to reflect on the status of Nordic progress towards Sustainable Development Goal $12^{41}$ and to provide direction on how to tackle the real

\footnotetext{
${ }^{36}$ Nordic Council of Ministers (2013) A Good Life in a Sustainable Nordic Region Nordic Strategy for Sustainable development.

${ }^{37}$ Larsen, M. and Alslund-Lantén, A. (2017). Bumps on the Road to 2030. Nordic Council of Ministers.

${ }^{38}$ Bauer, B., Watson, D., Gylling A.C. (2018). Sustainable Consumption and Production. An Analysis of Nordic progress towards SDG12, and the way ahead. Nordic Council of Ministers, 7, 10.

${ }^{39}$ Nordic Council of Ministers. (2017). Generation 2030

${ }^{40}$ Baver, B., Watson, D., Gylling A.C. (2018) Sustainable Consumption and Production. An Analysis of Nordic progress towards SDG12, and the way ahead. Nordic Council of Ministers.

${ }^{41}$ United Nations. 2018. Sustainable Development Goal 12 - Ensure sustainable consumption and production patterns. https://sustainabledevelopment.un.org/ sdg12
} 
tasks and challenges involved in implementing the 2030 Agenda. The report calls for a more holistic approach to the development of tourism and creating conditions that would help make tourism a more positive force in economic, environmental and social development. An important recommendation made in the report is for the Nordics to develop and implement tools to monitor sustainable development impacts for sustainable tourism that creates jobs and promotes local culture and products.

Despite serious challenges, there is determination and focus on sustainable development within Nordic cooperation and considerable effort has been put into backing this up with projects and initiatives. Nordic ministers have all agreed on giving sustainability top priority and decided that the strategy for sustainable development should be an overriding and cross-sectoral framework for other work of the Nordic Council of Ministers. ${ }^{42}$ The level of political determination for the mainstreaming of sustainability in all policy areas of Nordic Cooperation gives the hope that actions and objectives necessary to make real progress in the area of sustainable development within tourism will receive the necessary political backup and prioritisation.

Political backup and prioritisation are indeed crucial when it comes to sustainable development in the Nordic tourism sector. There is an array of best practice examples of sustainable solutions within Nordic tourism. ${ }^{43}$ However, despite the importance placed on sustainability on the national and Nordic levels and despite many initiatives and national policies that have the objective of working towards sustainability, there is a lack of coordination, objectives are unclear and monitoring tools are often not in place. ${ }^{44}$ The Nordics could all do better in setting clearer policy objectives for sustainability specific to tourism, both at the national levels and within Nordic cooperation. The formidable challenges posed by sustainability could indeed be a driver for Nordic cooperation. This is a field with no easy solutions and where the sharing of information, practices, technology and sheer effort is much needed.

\section{The Carbon Footprint of Tourism}

The carbon footprint of global tourism is a major concern which cannot be side-lined in the discussion on the sustainability of the sector. As global tourism grows, the carbon footprint of the industry has also grown rapidly. The increase has exceeded estimations and accounted for about $8 \%$ of global greenhouse emissions in 2013, four times more than previously estimated. ${ }^{45}$ The World Tourism Organization's estimate of carbon emissions from tourism is rather lower, or $5 \%$ of global emissions. Significantly, a massive $75 \%$ of that share originates from the transport sector, primarily aviation. ${ }^{46}$

Difficult questions need to be asked, such as is it really good for the planet, and in line with the UN Development goals and the commitment that all the countries have agreed to in the Paris Agreement, to be aiming at increasing growth in tourism and targeting long-haul markets?

\footnotetext{
${ }^{42}$ Nordic Council of Ministers (2013) A Good Life in a Sustainable Nordic Region Nordic Strategy for Sustainable development.

${ }^{43}$ Hillgrén A., Bröckl M., Descombes, L., Kontiokari V., and Halonen M. (2018). Nordic Best Practices. Relevant for UNEP $10 Y$ FP on Sustainable Tourism and Consumer Information. TemaNord 2016:546

${ }^{44}$ Baver, B., Watson, D., Gylling A.C. (2018) Sustainable Consumption and Production. An Analysis of Nordic progress towards SDG12, and the way ahead. Nordic Council of Ministers.

${ }^{45}$ Lenzen, M., Sun, Y.Y., Faturay. F., Ting Y.P., Geschke, A., Malik A. (2018). The Carbon Footprint of Global Tourism. Nature Climate Change. Volume 8 , 522-528

${ }^{46}$ World Tourism Organization. (2018). FAQ - Climate Change and Tourism: http://sdt.unwto.org/content/faq-climate-change-and-tourism.
} 


\section{TRAVELTECH}

Internationally, the travel and tourism industry is one of the fastest changing industries, quick to introduce or adapt cutting-edge technologies and business models. Disruptive digital technology has already transformed the industry and customer behaviour globally.

Internationally, travel technology is a priority area where there is considerable activity from start-up companies, investors and established companies. In the Nordics, the potential of innovation in the travel and tourism industry has been given less focus. Traveltech labs have been created all over the world: MTLab in Montreal, London \& Partners, Voyager $\mathrm{HQ}$ in New York, jetBlue Technology Ventures in the San Francisco Bay Area, to name a few.

There are obviously no easy solutions here, and the Nordic countries have taken different measures to tackle the environmental challenges of tourism. While Norway and Sweden have for instance implemented aviation taxes intended to reduce emissions, Denmark has been opposed to such measures, which it fears will undermine competitiveness. ${ }^{47}$

\section{Solutions Through Innovation and Technology} The real solutions to reducing carbon emissions from the largest polluters in tourism must come from technological innovation and pressure to increase competitiveness within the sector.

Globally, the travel and tourism industry is one of the fastest changing industries and one where disruptive technological changes have had a transformational impact. Internationally, travel technology is a priority area for start-up companies, investors and more established companies. This has not been the case to a similar extent in the Nordics, where there has not been much focus on innovation and technology in relation to the tourism sector. Projects that aim to achieve sustainability goals and lower carbon emissions through innovation and technological development are an important focus area for Nordic cooperation. For this type of initiative to have a real impact, decisive action backed by a strong political mandate is necessary. A Nordic network focusing on Traveltech could become a platform through which to identify and activate collaboration between public and private actors, technology developers and investors. Such a network must include the big businesses in Nordic tourism and the transport sector; aviation and cruise companies are an important part thereof.

\section{Nordic Best Practices}

In 2017, a network of public and private organisations in Norway, including Innovation Norway and key industry organisations, published a Roadmap for Sustainable Tourism. The roadmap sets out to define what characterises sustainable travel and tourism and to identify the challenges involved. A key objective of the roadmap is to give direction for moving towards sustainable travel and tourism by 2050 and to propose ways to achieve this goal. The roadmap, which is part of governmental policy, could set an example on how to tackle many of the tasks and concerns involved in working towards sustainability on Nordic regional levels. ${ }^{48}$

\footnotetext{
${ }^{47}$ Danish Ministry of Transport, Building and Housing. 2017, in Bauer, B., Watson, D., Gylling A.C. (2018). Sustainable Consumption and Production. An Analysis of Nordic progress towards SDG12, and the way ahead. Nordic Council of Ministers, 35

48 Innovasjon Norge (2017) Towards Sustainable Travel and Tourism in Norway. A roadmap.
} 


\section{MEASURING SUSTAINABILITY}

An important way to facilitate better policy and actions to achieve sustainability goals is to develop measurement tools and indicators to monitor the impact of tourism on destinations. Methodologies involving the assessment of Tourism Carrying Capacity are not a new idea. However, developing real indicators to measure the impact of tourism on the many different touching points between visitors and destinations, and translating such information into policy and priority actions is not so common in the Nordic region.

In an effort to do that, the Icelandic Ministry for Industries and Innovation initiated a project led by the Icelandic Tourism Task Force, on impact indicators for Icelandic tourism. The objective of the project is to develop indicators that cover a very comprehensive assessment of the impact of Icelandic tourism, taking into account economic, environmental and social parameters.

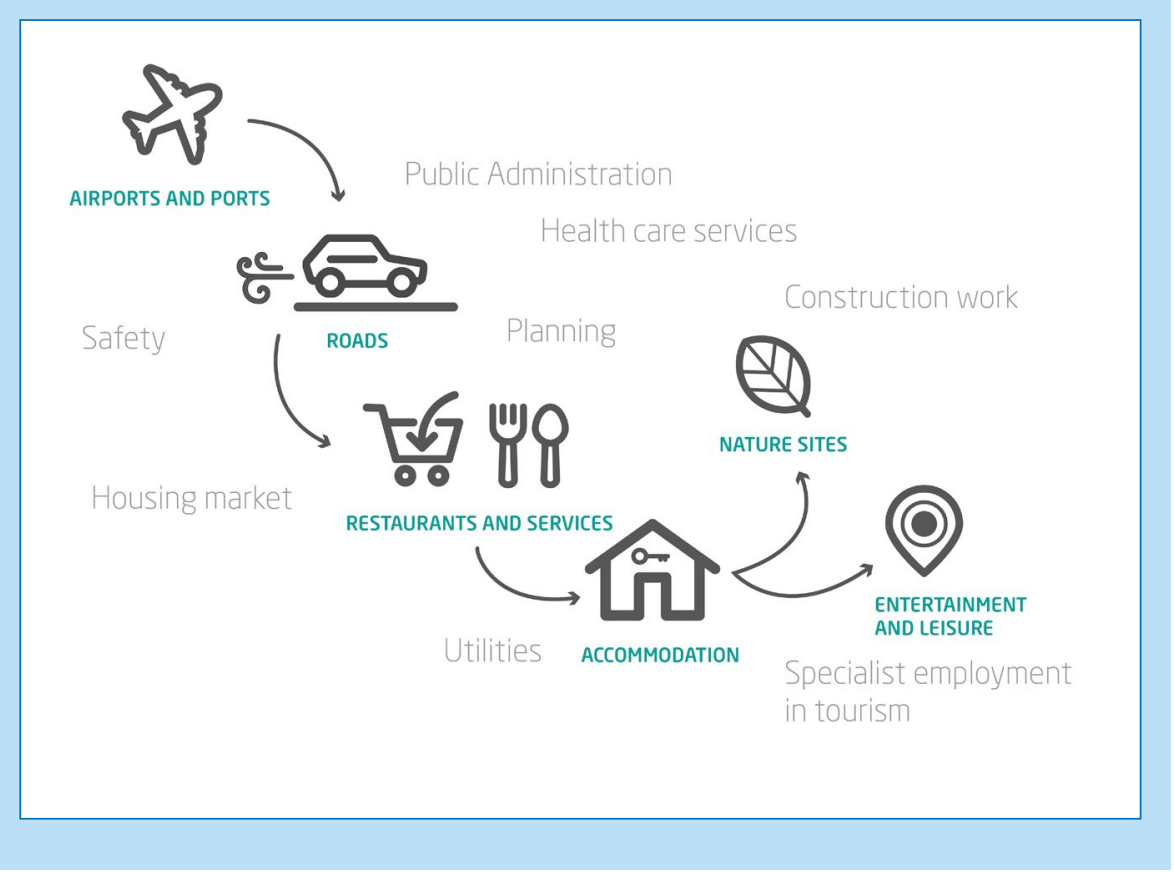

In Norway, the development of the Sustainable Destination Standard is led by Innovation Norway. The standard includes criteria and indicators that can be measured, registered and monitored. The standard covers nature, culture, environment, social values, community involvement and economic viability. The standard is a tool to work systematically, with a long-term view, towards sustainable destinations. Becoming a sustainable destination takes years of work with the whole local community working together. Measurable and continuous development is ensured through performance counts and by renewing the brand every three years. 
On a related note, a ministerial report on the carrying capacity of tourism in the country has been presented to the Icelandic parliament. ${ }^{49}$ The paper is an analysis of issues relating to the sustainability of tourism in the country and possible measures to manage the many different aspects and pressure brought on by the industry. A key recommendation made in the paper is the development of a Tourism Carrying Capacity assessment methodology (TCC) to manage the strain on nature, communities and infrastructures brought on by tourism. Other objectives include distribution of visitors, land use and measures to support sustainable economic development of the sector.

In 2017, the Norwegian government published a report on green competitiveness. A significant point made in the report is that although taking the climate challenge seriously is not free of cost, failing to do so will be even more costly;

"Those countries that are best at converting the challenge of becoming a low-emission society to opportunities will be the most competitive ones in the coming decades". 50

\section{Recommendations:}

- As political backup and prioritisation is crucial to sustainable development in the Nordic tourism sector, Nordic ministers are encouraged to set clear objectives and priorities for collaboration on sustainability goals in tourism, both on national and Nordic levels.

- Nordic ministers are encouraged to support the Nordic countries in developing a methodology for sustainable tourism strategies, followed by action plans and a monitoring scheme. This recommendation is in line with proposal 13/12B in the report "Sustainable Production and Consumption" published by the Nordic Council of Ministers. ${ }^{51}$ Developing and implementing tools to monitor the impact of tourism by tracking the impact it has at various levels, is an important requirement for more effective tourism policy development and destination management in the Nordics.

- A Nordic roadmap for sustainable tourism should be created and ambitious and measurable goals set, where regulations and infrastructure in tourism supports environmental objectives and sustainability of the sector. Better use can be made of already existing resources on a Nordic and national level through Nordic cooperation. A taskforce for effective exchange of best practices and policies should be established to facilitate this. The role of the taskforce would also be to outline challenges and explore and mobilise action.

- An effort must be made to encourage innovation, business development and new business models in the tourism sector to accelerate the transition towards sustainability of the sector. Existing organisational structures should be used to facilitate this, but new Nordic networks for knowledge sharing and best practice must be facilitated. An effort should be placed on cutting through barriers within Nordic and national organisations to access expertise and facilitate cooperation. The establishment of a Nordic Traveltech network can also contribute to this objective.

\footnotetext{
${ }^{49}$ Skýrsla ferðamála-, iðnaðar-, og nýsköpunarráðherra um polmörk ferðamennsku. (2018). Submitted to the 148th Icelandic parliament 2017 - 2018. https:// www.ferdamalastofa.is/static/research/files/skyrsla-radgerra-um-tolmork-2018pdf

50 Hedegaard, C. and Kreutzer, I. (2016). Green Competitiveness, 3.

${ }^{51}$ Baver, B., Watson, D., Gylling A.C. (2018) Sustainable Consumption and Production. An Analysis of Nordic progress towards SDG12, and the way ahead. Nordic Council of Ministers, 37.
} 


\section{Marketing Nordic Destinations}

\section{Collaboration and Competition}

All the Nordic countries have experienced growth in the importance and economic impact of tourism over the last years. There is, however, considerable variation in the type of destinations, services and markets on which the tourism sectors in the different countries rely. An important segment of the tourism market in the Nordics stems from European neighbours such as Germany, Netherlands, France and the United Kingdom. Visitors from within the Nordic region itself are among the top markets in all the Nordics. Finland and Iceland differ from the other Nordic Countries, Finland with important markets in Russia, Estonia and China, and Iceland with close connections to the United States. ${ }^{52}$

The Nordic countries have somewhat different visions regarding future markets, and there is competition within the region when it comes to attracting visitors. Visit organisations in the individual countries place emphasis on the importance of developing a range of markets, to diminish the risk of relying too heavily on any one source of income.

All the Nordic countries have effective marketing operations and strategies in place focusing on the individual countries and destinations within them. There are some differences in organisational structure between the countries which nonetheless seem to share many overall objectives. All countries aim at the "high-yield / low-impact" tourist and in their targeting seek to address challenges such as seasonality, sustainability and cultural integrity, while maintaining a positive image of the country and the experiences on offer. In some of the Nordics, there is concern that tourism is already reaching an upper limit and that the aim of marketing should therefore not be to increase the number of visitors, but rather to concentrate efforts on reaching the most valuable markets.

There is already considerable collaboration between Nordic Visit Organisations. A Nordic Analytic Group has met bi-annually to cooperate on analytics and market research with the objective to create better data benchmarks between the Nordic destinations and for knowledge sharing. The organisations have also jointly taken part in a number of events and initiatives over the years. There is however no common strategy or plan for such cooperation on the Nordic level.

National Visit Organisations have worked extensively on defining and developing specific markets and target groups and there is extensive specialisation on destination marketing in all countries. Internet marketing and the use of social media is an integral part of marketing efforts in all countries and all organisations work in close collaboration with the tourism industry.

Examples of this are for instance the "Inspired by Iceland" campaign that Promote Iceland has managed for several years in cooperation with the government and the private sector, and VisitDenmark's "Smart Tourism Strategy" which was launched in 2017. The strategy consists of three main initiatives, ${ }^{53}$

\footnotetext{
52 OECD (2018), OECD Tourism Trends and Policies 2018, OECD Publishing. Paris. http://dx.doi.org/10.1787/tour-2018-en 152- 157; 163-168; 190-194; 246-250: 276-280.

${ }^{53}$ OECD (2018), OECD Tourism Trends and Policies 2018, OECD Publishing. Paris. http://dx.doi.org/10.1787/tour-2018-en 155.
} 


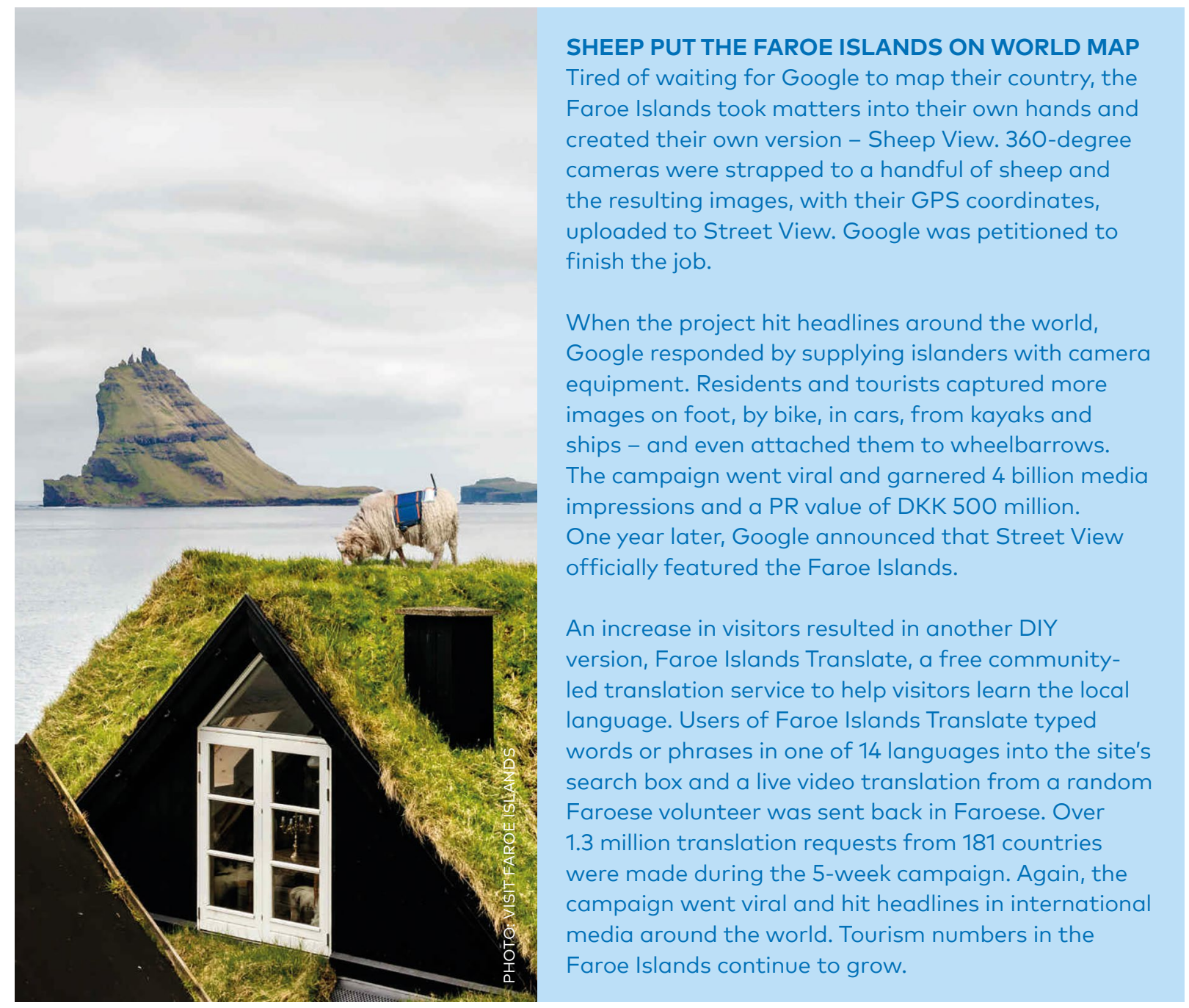

- Smart Marketing - Using mobile and social marketing channels to increase demand for Denmark as a tourist destination.

- Smart Working - Supporting the digitalisation of value chains in Danish tourism to increase coordination and cooperation between actors within Danish tourism.

- Smart Insights - Identifying relevant data and data sources and sharing and exchanging knowledge in order to optimise and encourage innovation in the marketing, product development and sales process.

These three initiatives are yet another example of the interdependency between marketing, destination management and the development of products and services. Destination development goes hand in hand with developing and attracting new markets.

\section{Long-haul Markets}

All the Nordics agree on the importance of future development in long-haul markets, particularly in China and elsewhere in Asia. This is an area where the Nordics also see the greatest potential for collaboration when it comes to marketing. The exception here may be Iceland, where there 
is currently great pressure on infrastructure and resources from the already growing number of visitors. What all the Nordics can agree on is the need to work strategically on research-based marketing with the view of increasing the value of each customer and increasing the competitiveness of the sector at all levels of the value chain.

Marketing brings to light the interdependency and complexity of the tourism sector, a reoccurring theme in all sections of this analysis. Marketing and destination management can be regarded as two sides of the same coin. Destination management and marketing are a precondition to managing seasonality and working towards sustainability in tourism. All these factors rely on strategic information gathering and knowledge sharing. Digitalisation is an integral part of all these themes. There is great potential for Nordic collaboration in all these fields, and the benefits can be considerable with regard to developing Nordic destinations and reaching the right markets.

In 2018, the Nordic Council of Ministers financed a joint project between the Nordic Visit Organisations (Destination Marketing Offices, DMOs), including DMOs from the self-governing regions. The DMOs selected COTRI - China Outbound Tourism Research Institute to research and provide recommendations on how best to approach strategic and desirable markets within China, with the objective of developing sustainable tourism growth from China to the Nordic region. ${ }^{54}$ The report is a product of Nordic collaboration on shared interests with the focus on long-haul marketing and can be perceived as a good platform for further collaboration between the Nordics in this field.

The focus of the analysis is on how Nordic destinations can develop their relationship with the Chinese market in a manner which yields more economic value while also developing in a sustainable way. Other points of interest are questions of how better to manage the seasonality of the Chinese market and facilitate geographical dispersion of Chinese tourists. To this end, the analysis focuses on the market segment of High Spending Free Individual Travellers (HiSpFITs), who, compared to package-group Chinese tourists, are likely to stay longer at each location, disperse wider and travel outside peek seasons while still paying for services and activities. ${ }^{55}$ Based on market intelligence and previous years' developments, the authors predict that the potential of the Chinese market will more than triple to 2022 if suitable products and services allow for it. ${ }^{56}$

Another objective of the analysis is to provide market information which can be used by Nordic DMOs to develop a strategy that can be used to increase awareness of the Nordic region as a whole in long-haul markets supported by Nordic Unique Selling Propositions (USPs) specific to China. To achieve this desired goal, the authors recommend that the Nordics improve their market analysis with a stronger focus on market segments with higher economic yield and less environmental impact. Any exploration of long-haul markets brings up questions about "Nordic branding" and the

\footnotetext{
${ }^{54}$ Arlt, W.G., Deng-Westphal, M., Taylor, M. and Yang, C. (2018). Chinese High Spending FITS Market Analysis Report. COTRI - China Outbound Tourism Research Insitute.

${ }_{55}^{5}$ Arlt, W.G., Deng-Westphal, M., Taylor, M. and Yang, C. (2018). Chinese High Spending FITS Market Analysis Report. COTRI - China Outbound Tourism Research Insitute. 1 - 2.

${ }^{56}$ Arlt, W.G., Deng-Westphal, M., Taylor, M. and Yang, C. (2018). Chinese High Spending FITS Market Analysis Report. COTRI - China Outbound Tourism Research Insitute. 5-12
} 


\section{ROVANIEMI}

Rovaniemi is a small city in the Lapland region of Finland, best known to the world as the Official Hometown of Santa Claus ${ }^{\oplus}$. Christmas in Rovaniemi is not a season: it's a state of mind. The city's most famous resident can be visited every day of the year in Santa Claus Village right on the Arctic Circle. Visit Rovaniemi is the brand manager of the Santa Claus Hometown ${ }^{\oplus}$.

Visit Rovaniemi is owned by the City of Rovaniemi and over 220 partner companies. Besides cooperating with owners and stakeholders, Visit Rovaniemi works closely with other regional tourist boards in Lapland, the Regional Council of Lapland, as well as with national organisations.

opportunities and challenges linked with the idea of a Nordic brand. The Nordic Council of Ministers has operated a special website to promote Nordic branding under the heading of www.thenordics. com. The objective of this site is to reflect common Nordic "values" and "ambitions" to the world. The Nordic branding platform is not meant to represent Nordic tourism in any particular way, rather to project a common Nordic image. Most Nordic visit organisations are aware of this branding platform, but in conversations with professionals within Nordic tourism, there was limited awareness of this initiative and how it could be used in destination marketing. Stronger cooperation between the Nordic branding initiative and businesses and organisations within Nordic tourism should be encouraged. The benefits of this include the opportunity to incorporate key issues and needs of Nordic tourism into further development of Nordic branding.

From the perspective of the long-haul markets, there also seem to be some confusion when it comes to what "The Nordics" or "Northern Europe", "Scandinavia" or "the Nordic countries" stands for. It appears that there are opportunities for jointly working on improving the perception of a Nordic brand for tourism. The promotion of a Nordic brand must of course be linked to strong destination development within the countries.

\section{Recommendations:}

- The collaboration between the Nordic Visit Organisations should be continued. Cooperation on developing long-haul markets is the obvious topic of mutual interest.

- Opportunities of developing the Nordic brand further should be explored in closer cooperation with the tourism sector.

- An evaluation should be carried out of whether existing structures, such as Vestnorden and NATA, could be used as models for successful cooperation for the Nordic region.

- The necessary marketing efforts to encourage long-haul visitors to stay longer and travel between Nordic destinations should be explored, not least with the objectives of tackling the environmental impact of long-haul tourism and the importance of sustainability goals. 


\section{Seasonality, Destinations and Competitiveness}

\author{
Seasonality - a Common Nordic challenge \\ Seasonality is an important issue in Nordic tourism \\ and it is high on the agenda among experts within \\ the sector. In all of the countries, seasonality \\ is mentioned as one of the biggest challenges \\ that the tourism industry is facing. Imbalanced \\ seasonal distribution of visitors throughout the \\ year, and within different regions, impacts a whole \\ range of other factors. Like almost everything \\ else in tourism, the different forces at play are \\ closely interlinked while at the same time being \\ individually important to the value chain of the \\ entire sector. Seasonality is a key element in an \\ intricate combination of factors. The issues at \\ stake are many: regional development, destination \\ development, business competitiveness and \\ innovation, employment and competence building, \\ dispersion of visitors geographically, economic, \\ social and environmental sustainability and \\ overcrowding.
}

Approaches to tackle seasonality must consist of a combination of measures. These include marketing, statistics and information sharing, digital competence, business development and training. All these are areas where more decisive action and effort is needed in all the Nordic countries. This is an area where, because of the many different interests and tasks, public and private sectors must collaborate.

A recent study carried out by the Icelandic Tourist Board in collaboration with KPMG revealed striking information about the operating conditions and the financial standing of tourism companies in Iceland ${ }^{57}$ and demonstrates well the problems of seasonality in tourism and the difficult operating conditions in the rural areas. The study, which is restricted to hotels, car rentals and bus companies, builds on financial information from 2017 and 2018. Its findings show that the economic environment of the companies in question is fragile, and that despite an increase in the numbers of visitors, profits in the sector have decreased.

Another finding of the study is that the financial returns of the companies are considerably worse in regions outside the capital area than of those located within it. In fact, the profitability of tourism companies seems to decrease the further away from the capital they are located. Here, the reality of running a tourism business does not seem to match the expectations that tourism will be a driver for economic growth in rural areas. The industry is fragile and seasonal, and that situation can be hard to combat. While it may not be possible to draw conclusions applicable to the other Nordics from this Icelandic study, it does nevertheless raise poignant questions, which could be valid to other Nordic countries and regions.

\section{Destination Management Planning}

Many of these issues and concerns can be brought together under the heading of Destination Management Planning (DMP) which can be described as a methodology for strategic planning in tourism, drawing on the strengths, culture and resources of destinations. DMP can be a useful tool to highlight opportunities for using local resources and destinations in the development of products and services and to involve the locals in agreeing on objectives and parameters for local tourism, i.e. where to build up, what to market in the region, etc. DMP can also be a platform for individual companies to examine their business viability and explore new opportunities. DMP 


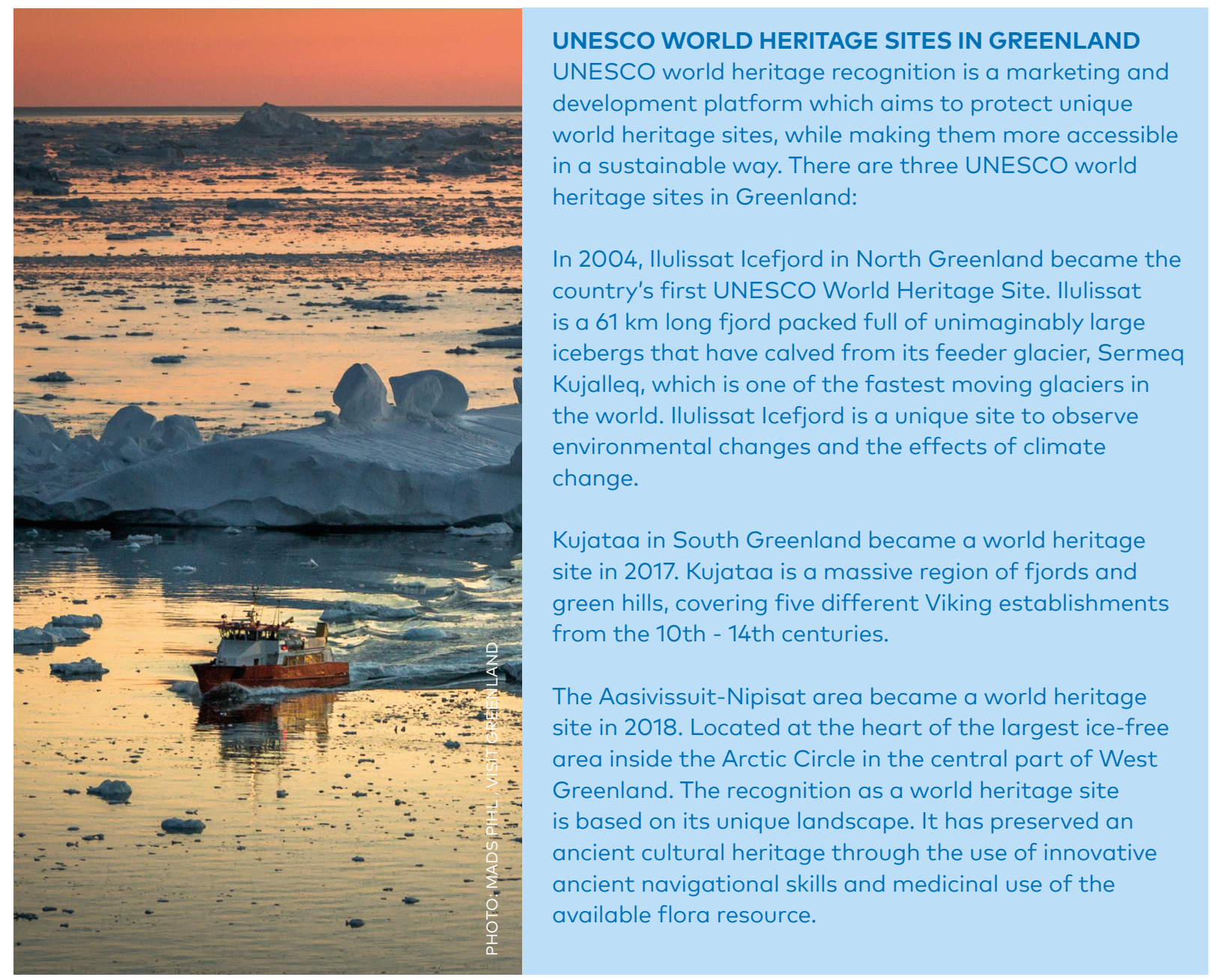

projects have already led to improvements within the Nordic region, but much still needs to be done to strengthen competence and business in the tourism sector. A more decisive long-term strategy, backed up by professional support, is necessary at the level of individual SMEs, networks and regions.

Perhaps the main reason for supporting DMP initiatives further is the immense opportunities in creating value through developing destinations all over the Nordic region, drawing on the different experiences which the regions can offer. Successful practices within DMP programmes rely on creating networks of cooperation between tourism stakeholders and public and private interest, regionally and locally. There are plenty of good practices and tools in the Nordic "toolbox" for DMP. These need to be shared more effectively and developed further.

\section{Sharing Knowledge and Best Practices}

It is important to keep in mind that there is a lot of experience and know-how within Nordic tourism and experts within the sector are very aware of the challenges involved. Much development, innovation and competence building is taking place and there 


\section{WONDERFUL COPENHAGEN}

Wonderful Copenhagen is the leading tourism agency for the Greater Copenhagen region, responsible for strategy, development and cooperation between public and private partners. In its strategy for 2020, Wonderful Copenhagen professed "the End of the Era of Tourism as We Know It" and a move "Towards a New Beginning of Localhood".

With this bold statement, Wonderful Copenhagen set a new tone, claiming that the days of tourists as mass consumers are over and the segmentation between business and leisure, city and countryside, culture and cycling, is outdated and unhelpful. Wonderful Copenhagen presents a far more intricate and complex picture of tourism where visitors are "temporary locals" seeking an emotional connection to an instantly shared experience. This means that marketing and communicating as well as the conception of the audience itself must be radically reassessed.

Wonderful Copenhagen also has a bold statement to make on sustainability, declaring that sustainable growth should be considered the only relevant kind of growth. A key idea in Wonderful Copenhagen's sustainability strategy "Tourism for Good" is that tourism is not a goal in itself, and that it should rather be regarded as a means to a sustainable end; tourism should contribute positively to society, to building better cities and destinations for locals and visitors alike as a driver of positive change.

are many examples of successful projects and best practices in tourism in all the Nordics. More strategic and comprehensive Nordic cooperation to tackle these challenges in order to share knowledge and best practices is especially important to smaller tourism companies who struggle with challenging operational conditions and weak infrastructure.

Education and training are also important issues for Nordic tourism, and this was highlighted by industry representatives. There are quite a lot of resources within individual countries to tackle this, both at the level of vocational colleges and at the university level. Support measures to increase competence and to provide SMEs in the tourism sector with the right tools, skills and networks to tackle their specific challenges need to be given more emphasis. Fast changes in the industry and markets make it a constant challenge to keep up with changing demands. Education and training is needed for those employed at every level within tourism, but also for those working to support the sector in the public and private support ecosystem. This is an area where a Nordic network for knowledge sharing and exchange of best practices could be effective.

\section{Business Innovation and Competitiveness}

Many smaller companies, who make up a large part of the tourism sector, are financially fragile and have limited capacity to adopt new technologies and make the necessary changes to stay competitive. In all the Nordic countries there is a need to support business development and innovation in the tourism sector, or connect the sector to innovation and business development in other sectors that could also be used in tourism. Practices that encourage product development and innovation, collaboration between stakeholders and the adaption of new technologies and marketing tools need to become a larger part of business practices in the tourism sector. To a considerable extent, this must happen at the national and local levels, but again, Nordic networks, collaboration and the exchange of information and best practices could be of great benefit here. 


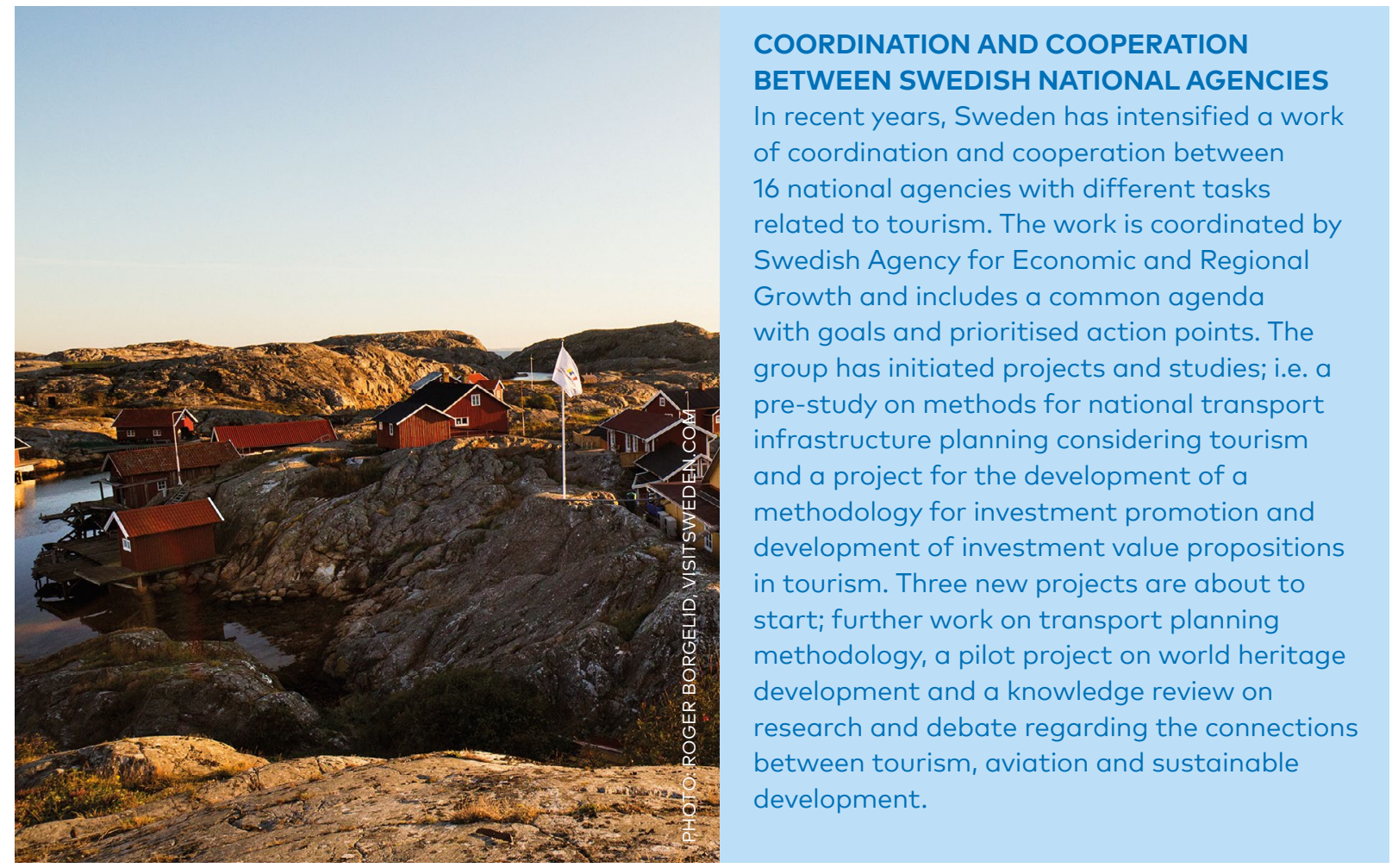

\section{Recommendations:}

- An effort must be made to encourage innovation, business development and new business models in the tourism sector to accelerate the transition towards sustainability and growth within the sector.

- Existing organisational structures can be used to facilitate this, but new Nordic networks for knowledge sharing and best practice must be encouraged. An effort should be placed on cutting through barriers within Nordic and national organisations to access expertise and facilitate cooperation.

- Collaboration between Nordic tourism support agencies should include knowledge sharing, data exchange and market research. A special emphasis should be placed on collecting statistical information across the Nordic region with comparable indicators.
- DMP projects have already led to improvements within the Nordic region, but much still needs to be done to strengthen competence and business in the tourism sector. A more decisive long-term strategy, backed up by professional support, is necessary at the level of individual SMEs, networks and regions. There are plenty of good practices and tools in the Nordic "toolbox" for DMP. These need to be shared more effectively and developed further. 


\section{Section III}

\section{RECOMMENDATIONS AND CONCLUSIONS}

Increased Nordic Cooperation on Tourism or Not?

The first questions to be answered before further conclusions are drawn from the analysis are: Is there interest, need and will in the Nordic region to cooperate further and more formally on tourism? And if so, in what form?

Based on interviews in all of the Nordic countries and the autonomous regions, it is clear that overwhelming majority of participants is of the opinion that further Nordic cooperation and coordination on issues relating to tourism is beneficial and would strengthen national tourism as well as the whole Nordic region as a destination. Many in fact believe that increased cooperation is simply necessary.

\section{"The questions are becoming more and more complex and we need a more sophisticated response to tackle it - therefore we need more cooperation". \\ Sweden}

Most agree that the initiative should come from above, i.e. from the Nordic governments/ministers, and that political backing is essential. It needs to involve the tourism sector, and participation and commitment from industry, large and small, is essential. The cooperation should be practical on issues that are relevant and pressing in the region as a whole. The cooperation should be formal - yet flexible, structured - while at the same time being lean and efficient. There needs to be a responsible Nordic driver, a facilitator, with a clear mandate to initiate cross-national projects and bring relevant actors together.

"We want something flexible, but still someone has to take the initiative for things to happen".

Norway

"The trend is clearly that nobody wants heavy structures, but if it is too light, it doesn't lead to anything permanent. Then, the responsibility is unclear". Finland

"Somehow it just needs to be fast enough - easy enough - it needs to be agile".

Finland

Existing structures, both Nordic and national, should be used and funds should be spent on practical projects rather than on organisational overhead. Funding needs to be secured from within the Nordic system, as all of the national actors agree that every country's prioritisation would always be to fund national programmes first.

It is important to stress that in Nordic cooperation there should be additional money".

Norway

Most of the experts interviewed, were positive towards the Nordic system, but knowledge of the 
work of the Nordic Council and Nordic Council of Ministers seemed rather limited, especially in the private sector.

Most agree that there is much room for cooperation, as all of the countries are experiencing similar development within their tourism sectors, although on different levels. Therefore, flexibility is essential, and it should not be required that all countries participate in every project. Knowledge exchange and information sharing is thought to be beneficial and likely to increase competence across the board. It is believed to be important when it comes to strengthening national tourism as well as the Nordic region as a destination.

The main themes of this analysis - sustainability, digitalisation, marketing, seasonality, knowledge sharing, innovation and business competence are all areas where there is much consensus on exploring further cooperation. Projects should be carefully selected and have a clear focus. The cooperation should not be conducted just for the sake of cooperating, but rather be about practical issues and solving common problems. The focus should be on common challenges and commitments and not on issues where the countries may disagree or have conflicting interests.

\section{"It is important to remove areas where you have conflict. It is also important to identify Nordic added value". \\ Denmark}

\section{Recommended Organisational Structures}

In order to best facilitate Nordic cooperation on tourism in a way that accommodates the analysis in this report as well as the priorities and views of Nordic tourism experts interviewed, the recommendation is to set up an organisational framework that supports several objectives at once; a lean structure, but with a clearly defined responsibility, commitment and mandate, involving both public and private sectors from the Nordics.

\section{Nordic Task Force on Tourism and Nordic Tourism Facilitator}

The recommendation is twofold, to create a Nordic

Task Force on Tourism and a position of a Nordic Tourism Facilitator who will report both to the Nordic Council of Ministers and the Task Force.

The facilitator will have the main objective to identify areas of cooperation relating to tourism and, initiate, follow-up and navigate tourism issues through the Nordic system and work with national governments and private sector tourism actors on specific projects.

The Task Force should have representatives from all of the Nordic countries and the autonomous regions, both from the public and private sectors.

Together, the facilitator and the Task Force will remove silos and simplify communication channels and be able to secure a cross-national and crosssectoral tourism focus on relevant projects that are of mutual Nordic interest and concern.

The goal is to use existing structures, both Nordic and national, with a creative twist. As political backing is vital, the backup, funding and mandate needs to come directly from the Nordic Council of Ministers (MR-N). The intended outcome is a more strategic, focussed and results driven Nordic cooperation on tourism to the benefit of the whole region as well as the respective countries. 


\section{NORDIC COUNCIL OF MINISTERS}

$\uparrow$

Nordic Tourism Facilitator

$\uparrow$

Nordic Taskforce on Tourism

(Public Sector and Industry)

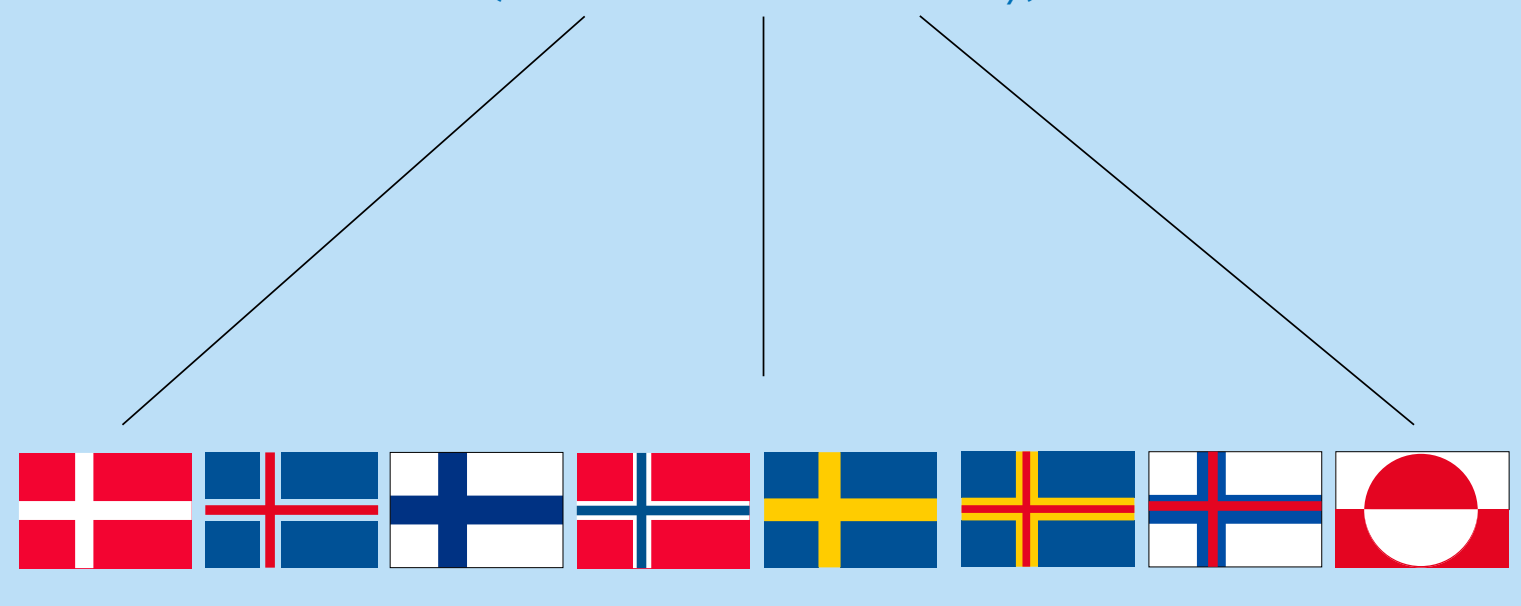

AREAS OF COOPERATION

- Sustainability - Seasonality

- Digitalisation - Research and

- Marketing Information Sharing

- Innovation - Best Practices 


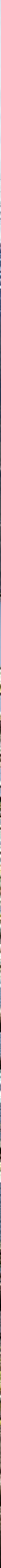




\section{List of Experts Interviewed}

\begin{tabular}{|c|c|c|c|}
\hline & Name & Organisation & Position \\
\hline \multirow[t]{8}{*}{ Denmark } & Anders Thusgaard & $\begin{array}{l}\text { Ministry of Industry Business } \\
\text { and Financial Affairs }\end{array}$ & Head of Division \\
\hline & Ann-Sofie Mærsk & Resonans Kommunikation & Advisor \\
\hline & Dorthe Barsoe & Tivoli Gardens & $\begin{array}{l}\text { Vice President, Brand \& } \\
\text { Communications }\end{array}$ \\
\hline & Eva Thybo & VisitDenmark & $\begin{array}{l}\text { Fundraising \& relationship } \\
\text { manager, Forretningsudvikling }\end{array}$ \\
\hline & Jakob Rasborg & Resonans Kommunikation & Director \\
\hline & Lars Ramme Nielsen & $\begin{array}{l}\text { The Danish Chamber of } \\
\text { Commerce }\end{array}$ & $\begin{array}{l}\text { Head of Tourism, Experience } \\
\text { Economy and Welfare }\end{array}$ \\
\hline & Michael Dithmer & $\begin{array}{l}\text { Ministry of Industry Business } \\
\text { and Financial Affairs }\end{array}$ & Permanent Secretary \\
\hline & Sune K. Jensen & Danish Industries & $\begin{array}{l}\text { Head of Tourism and Experience } \\
\text { Economy }\end{array}$ \\
\hline \multirow[t]{9}{*}{ Finland } & Heili Mäki-Fräntti & $\begin{array}{l}\text { Association of Finnish Travel } \\
\text { Agents AFTA }\end{array}$ & Managing Director \\
\hline & Kristiina Hietasaari & Business Finland, Visit Finland & $\begin{array}{l}\text { Director, Head of Product and } \\
\text { Content }\end{array}$ \\
\hline & Miia Porkkala & AhoGroup Oy & Chairman of the Board \\
\hline & & Tourism Cooperation Group & Chair \\
\hline & Paavo Virkkunen & Business Finland, Visit Finland & $\begin{array}{l}\text { Head of Visit Finland, Executive } \\
\text { Director of Business Finland }\end{array}$ \\
\hline & Pihla Väänänen & $\begin{array}{l}\text { Ministry of Economic Affairs } \\
\text { and Employment }\end{array}$ & Senior Specialist \\
\hline & Sanna Kärkkäinen & Visit Rovaniemi & Managing Director \\
\hline & Timo Lappi & $\begin{array}{l}\text { The Finnish Hospitality } \\
\text { Association - MaRa }\end{array}$ & Managing Director \\
\hline & Toumas Ylitalo & $\begin{array}{l}\text { Service Sector Employers - } \\
\text { PALTA }\end{array}$ & Advisor, Industrial Policy \\
\hline \multirow[t]{4}{*}{ Iceland } & Inga Hlín Pálsdóttir & Promote Iceland & Director, Visit Iceland \\
\hline & Óskar Jósefsson & Tourism Task Force & Chief Executive Officer \\
\hline & Skarphéðin Berg Steinarsson & Icelandic Tourist Board & Director General \\
\hline & $\begin{array}{l}\text { Pórdís Kolbrún Reykfjörð } \\
\text { Gylfadóttir }\end{array}$ & $\begin{array}{l}\text { Ministry of Industries and } \\
\text { Innovation }\end{array}$ & $\begin{array}{l}\text { Minister of Tourism, Industry } \\
\text { and Innovation }\end{array}$ \\
\hline \multirow[t]{9}{*}{ Norway } & Bente Bratland Holm & Innovation Norway & Director VisitNorway \\
\hline & Björn Krag Ingul & Innovation Norway & $\begin{array}{l}\text { Head of Sustainable Tourism and } \\
\text { Food }\end{array}$ \\
\hline & Camilla Lee Maana & $\begin{array}{l}\text { The Norwegian Confederation } \\
\text { of Trade Unions - LO }\end{array}$ & Advisor \\
\hline & Endre Kildal Iversen & Menon Economics & Senior Economist \\
\hline & Jens Petter Hagen & $\begin{array}{l}\text { The Norwegian United } \\
\text { Federation of Trade Unions }\end{array}$ & Advisor \\
\hline & Margarete Bergmål & $\begin{array}{l}\text { Ministry of Trade, Industry and } \\
\text { Fisheries }\end{array}$ & Senior Advisor \\
\hline & Marte Ludviksen & $\begin{array}{l}\text { Ministry of Trade, Industry and } \\
\text { Fisheries }\end{array}$ & Higher Executive Officer \\
\hline & Per Arne Tuftin & $\begin{array}{l}\text { Norsk Reiseliv - Norwegian } \\
\text { Tourism Partners }\end{array}$ & Director \\
\hline & Stein Ove Rolland & Innovation Norway & Special Advisor \\
\hline
\end{tabular}




\begin{tabular}{|c|c|c|c|}
\hline \multirow[t]{9}{*}{ Sweden } & Anna Hag & Visita - Svensk Besöksnäring & Tourism Industry Expert \\
\hline & Caroline Strand & Visit Stockholm & Acting Chief Executive Officer \\
\hline & Erika Rosander & $\begin{array}{l}\text { Swedish Agency for Economic } \\
\text { and Regional Growth - } \\
\text { Tilväxtverket }\end{array}$ & $\begin{array}{l}\text { Project Manager External } \\
\text { Partnerships in Tourism }\end{array}$ \\
\hline & Håkan Hillefors & $\begin{array}{l}\text { Ministry of Enterprise and Inno- } \\
\text { vation }\end{array}$ & Deputy Director General \\
\hline & Lars Söderlind & $\begin{array}{l}\text { Ministry of Enterprise and } \\
\text { Innovation }\end{array}$ & Specialist \\
\hline & Linda Ahlford & $\begin{array}{l}\text { Swedish Association of Local } \\
\text { Authorities and Regions }\end{array}$ & Project Leader \\
\hline & Linn Uggerud & Svensk Turism AB & Project Manager \\
\hline & Lotta Andersson & Visit Stockholm & $\begin{array}{l}\text { Director Marketing and Analysis } \\
\text { Department }\end{array}$ \\
\hline & Tina Olsson & Visit Sweden & Head of Strategic Development \\
\hline \multirow[t]{2}{*}{ Åland } & Camilla Gunell & Government of Åland & $\begin{array}{l}\text { Minister of Industry, Trade and } \\
\text { Environment }\end{array}$ \\
\hline & Terese Flöjt & City of Mariehamn & Business Developer \\
\hline \multirow{2}{*}{$\begin{array}{l}\text { The Faroe } \\
\text { Islands }\end{array}$} & Guðrið Højgaard & Visit Faroe Islands & Director \\
\hline & Oyvindur av Skarði & Ministry of Trade and Industry & Advisor \\
\hline \multirow[t]{2}{*}{ Greenland } & Idrissia E. Y. Thestrup & Visit Greenland & Senior Consultant \\
\hline & Mads Lumholt & Visit Greenland & $\begin{array}{l}\text { Senior Consultant, Market } \\
\text { Research }\end{array}$ \\
\hline \multirow{3}{*}{$\begin{array}{l}\text { Nordic } \\
\text { Council } \\
\text { Secretariat }\end{array}$} & Johan Lindblad & The Nordic Council Secretariat & Senior Consultant \\
\hline & Tobias Grut & Nordic Council of Ministers & Brand Manager \\
\hline & Trine Schmidt & Nordic Council of Ministers & $\begin{array}{l}\text { Project Coordinator, Expert } \\
\text { Group for Sustainable } \\
\text { Development }\end{array}$ \\
\hline
\end{tabular}


Alami, T., Aria Taymaz Tahmasebi. (2016) Sustainable and smart destination management. Opportunities for the DMO to act as an intelligent agent among destination stakholdrs. Umeå School of Business and Economics. (Master thesis).

Arlt, W.G., Deng-Westphal, M., Taylor, M. and Yang, C. (2018). Chinese High Spending FITS Market Analysis Report. COTRI China Outbound Tourism Research Insitute.

Baver, B., Watson, D., Gylling A.C. (2018). Sustainable Consumption and Production. An Analysis of Nordic progress towards SDG12, and the way ahead. Nordic Council of Ministers.

Besöksnäringens Myndighetsgrupp. (2019) Tilsammans för en stark och hållbar besöksnäring 2019-2021.

Danish Ministry of Transport, Building and Housing. 2017, in Baver, B., Watson, D., Gylling A.C. (2018). Sustainable Consumption and Production. An Analysis of Nordic progress towards SDG12, and the way ahead. Nordic Council of Ministers, 35

Det Kongelige Nærings- og Fiskeridepartement. (2016-2017). Meld.St. 19. Melding til Stortinget. Opplev Norge - unikt og eventyrlig.

Direction Générale Des Enterprises, Paris\&Co, Maire de Paris. (2018). Trend Book \#2. The Great Trends in Tourism Now and in the Future.

Eðvarðsson, A.G. (2018). Könnun á afkomu fyrirtækja í ferðabjónustu í krefjandi rekstrarumhverfi. Icelandic Tourist Board and KPMG.

Erhvervsministeriet (2016). Growth in Denmark. Danish Tourism 2025. A National Strategy for Danish Tourism - In Brief. (Unofficial translation), 3.

Erhvervsministeriet. (2014). Danmark i arbejde. Vækstplan for dansk turisme.

Erhvervsministeriet. (2016). Turismestrategier for de nordiske lande. (Unpublished draft).

Eurostat. (2016). Tourism Satellite Accounts in Europe 2016 Edition. Eurostats Statistical Reports.

Federal Chancellery and Federal Ministry of Science, Research and Economy. (2016). Digital Roadmap Austria.

Ferðamálaáætlun 2011-2020 Pingsályktunartillaga. www. althingi.is.

Hedegaard, C. and Kreutzer, I. (2016). Green Competitiveness,

Hillgén. A., Bröckl, M., Descombes, L., Kontiokari, V., Halonen. M. (2016). Nordic Best Practices Relevant for UNEP 1OYFP on Sustainable Tourism and Consumer Invormation. Nordic Council of Ministers. TemaNord 2016:546.
Innovasjon Norge. (2017). Standard for Bærekraftig reisemål Kriterier og indikatorer.

Innovation Norway. (2014). Tourism strategy 2014-2020.

Innovation Norway. (2017). Towards Sustainable Travel and Tourism in Norway. A Roadmap.

Kristjánsdóttir, S. (2016). Tourism and Technology; Does digital capacity of tourism impact the sustainability of Icelandic tourism?

Larsen, M. and Alslund-Lantén, A. (2017). Bumps on the Road to 2030. Nordic Council of Ministers.

Lenzen, M., Sun, Y.Y., Faturay. F., Ting Y.P., Geschke, A., Malik A. (2018). The Carbon Footprint of Global Tourism. Nature Climate Change. Volume 8, 522-528.

Ministry for Industry, Energy and Tourism, Spain. (2015). Smart Destinations Report: building the future.

Ministry for the Environment and Natural Resources. (2018). Stefnumarkandi landsáætlun um uppbyggingu innviða til verndar náttúru og menningarsögulegum minjum. Draft for review.

Ministry of Economic Affairs and Employment of Finland. (2015). Achieving more together - the Roadmap for Growth and Renewal in Finnish Tourism for 2015-2025.

Ministry of Economic Affairs and Employment of Finland. (2018). "Tourism Actors in Finland". Presentation.

Ministry of Industries and Innovation and the Icelandic Trave Industry Association. (2015). Roadmap for Tourism in Iceland.

Ministry of Industries and Innovation, Tourism Task Force. 2018. Álagsmat umhverfis, innviða og samfélags gagnvart fjölda ferðamanna á Íslandi. 1. áfangi; Próun vísa fyrir álagsmat.

Ministry of Industries and Innovation. (2015) Road Map for Tourism in Iceland.

Ministry of Trade and Industry. Government of the Faroe Islands. (2001). Tourism Industry Policy.

Nordic Council of Ministers. (2013). A Good Life in a Sustainable Nordic Region Nordic Strategy for Sustainable Development.

Nordic Council of Ministers. (2017). Bumps on the Road to 2030 .

Nordic Council of Ministers. (2017). Generation 2030.

Nordic Council of Ministers. (2017). Sustainable Development Action - The Nordic Way. Implementation of the Global 2030 Agenda for Sustainable Development in Nordic Cooperation. 
Nordic Council of Ministers. (2018). Nordic Co-operation Programme for Business and Innovation Policy 2018-2021.

Nordic Council of Ministers. (2018). Sustainable Consumption and Production - An Analysis of Nordic Progress Towards SDG12, And the Way Ahead. Swedish Presidency 2018.

OECD. (2018). OECD Tourism Trends and Policies 2018. OECD Publishing.

OECD/United Nations Environment Program. (2011). Climate Change and Tourism Policy in OECD Countries.

OECD Studies on Tourism, OECD Publishing

Paavonen, M. (2018). Digitaloudesta kasvua 2018 - tutkimus. Palvelualojen työnantajat Palta ry.

Resonans Kommunikation. (2016). Afrapportering Dialogmøde om nordisk turismesamarbejde. (Presentation for the Danish Presidency of Nordic Council).

Resonans Kommunikation. (2016). Afrapportering Undersøgelse af nordisk turismesamarbejde. (Presentation for the Danish Presidency of Nordic Council).

Sheehan, L., Vargas-Sánches, A., Presenza, A., Abbate, T. (2016) The use of Intelligence in Tourism Destination Management: An Emerging Role for DMOs. International Journal of Tourism Research, Int. J. Tourism Res., 18: 549-557.

Skýrsla ferðamála-, iðnaðar-, og nýsköpunarráðherra um polmörk ferðamennsku. (2018). Submitted to the 148th Icelandic parliament 2017-2018.

https://www.althingi.is/altext/pdf/148/s/0717.pdf

Statens offentliga utredningar, SOU. (2017). Ett land att besöka. En samlad politik för hållbar turism och växande besöksnäring. Betänkande av Utredningen Sveriges besöksnäring, Statens offentliga utredningar, Stockholm 2017, 49.

Swedish Agency for Economics and Regional Growth. (2015) Tourism in Sweden 2015.

Thybo, E. (2016) Nordisk Turisme. Nordisk Session i Helsinki (Presentation).

Trafikverket. (2017). Turismens samhällsekonomiska effekter - Förstudie om utvecklingsbehovet av bättre metoder och modeller i den nationella transportinfrastrukturplaneringen. Trafikverket. 2017:035.

United Nations. (2018). Sustainable Development Goal 12 - Ensure sustainable consumption and production patterns. https://sustainabledevelopment.un.org/sdg12

Utanríkis- og Vinnumálaráðið. (2016). Ferðavinna i Føroyum Ein Ábyrgdafull og burðardygg leið.
Vaarala. M. (2006). Sustainable Model for Arctic Regional Tourism (SMART). State Provincial Office of Lapland.

VisitDenmark. (2017). Smart Storytelling. Consumer Content Strategy 2017

VisitDenmark. (2018). Turismen i Danmark - skaber vækst of arbejdspladser i hele Danmark.

Visit Faroe Island. (2016) Virkisætlan.

Visit Greenland. (2017). Tourism Strategy 2016-2019, 23.

Vuorela, P., Listenmaa, J., Ahomäki, M., Kultanen, H. (2018)

Digitaloudesta Kasuva 2018, Palvelualojen työnantajat Palta ry.

Wonderful Copenhagen. (2018). The End of Tourism as we Know it. Strategy 2020.

World Economic Forum. (2017). The Travel \& Tourism Competitiveness Report 2017. Paving the way for a more sustainable and inclusive future.

World Tourism Organization. (2018). FAQ - Climate Change and Tourism: http://sdt.unwto.org/content/faq-climatechange-and-tourism.

World Tourism Organization. (2018). FAQ - Climate Change and Tourism: http://sdt.unwto.org/content/faq-climatechange-and-tourism.

World Tourism Organization. (2018). Tourism and the Sustainable Development Goals - Journey to 2030.

World Tourism Organization. UNWTO, (2017) Tourism Highlights. 2.

World Tourism Organization. UNWTO. (2018). Annual Report 2017, 9-16.

Ylitalo T. (2018). Palta - A pioneer in new work. (Presentation).

Øian, H., Fredman, P., Sandell, K., Sæpórsdóttir, A.D.

Tyrväinen, L., and Søndergaard Jensen, F. (2018) Tourism, nature and sustainability. A review of Policy Instruments in the Nordic countries. Nordic Council of Ministers. TemaNord 2018:534. 


\section{Internet Sources}

http://corporate.greenland.com/en/about-visit-greenland/

http://corporate.greenland.com/media/8043/

turismestrategi_eng_light_senest.pdf

http://corporate.greenland.com/media/8043/

turismestrategi_eng_light_senest.pdf

http://www.naturaliceland.is/en/

http://www.northatlantic-islands.com/about-nata.html

http://www.ttoscandinavia.com/faroe-islandsnew-tourismstrategy/

http://www.visitaland.org/visit-aland-in-english/

http://www.visitaland.org/wp-content/uploads/sites/3/ 2013/09/turismstrategi-2012.pdf

http://www.visitaland.org/wp-content/uploads/sites/3/

2015/11/Rapport-Turismens-på-Åland-2016.pdf

http://www.visitfinland.fi/en/

https://tillvaxtverket.se/download/

18.59ff66f1157d260336b52dOc/1477920508755/

Tourism\%2Oin\%20Sweden\%202015.pdf

https://tillvaxtverket.se/om-tillvaxtverket/omwebbplatsen/sok.html?query=Handbok+internat.

+investeringar+i+svensk+bes\%C3\%B6ksn\%C3\%A4ring+mars $+2018$

https://www.ferdamalastofa.is/en/about-us/tourismstrategy-2011-2020 https://www.gstcouncil.org/innovation-norway-sustainable -destination-standard-is-now-a-gstc-recognized-standard/

https://www.hotrec.eu/about-us/mission-vision/

https://www.innovasjonnorge.no/globalassets/reiseliv/ tourism-strategy-innovation-norway-2014-2020.pdf

https://www.inspiredbyiceland.com/

https://www.islandsstofa.is/en/about

https://www.regeringen.se/49bbc4/contentassets/ b1cadc3d48b34366957aa75aadb39423/en-politik-for-enlangsiktigt-konkurrenskraftig-svensk-turistnaring-prop.20040556

https://www.regjeringen.no/no/dokumenter/meld.-st.-1920162017/id2543824/sec1

https://www.researchgate.net/publication/ 306498584_Gauging_the_importance_of_tourism_in_Aland

https://www.stjornstodin.is/calendar-event/alagsmatthroun-alagsvisa-1-afangi

https://www.visitrovaniemi.fi/

www.ferdamalastofa.is

www.innovasjonnorge.no/en/start-page

www.sms.fo

www.stat.gl 


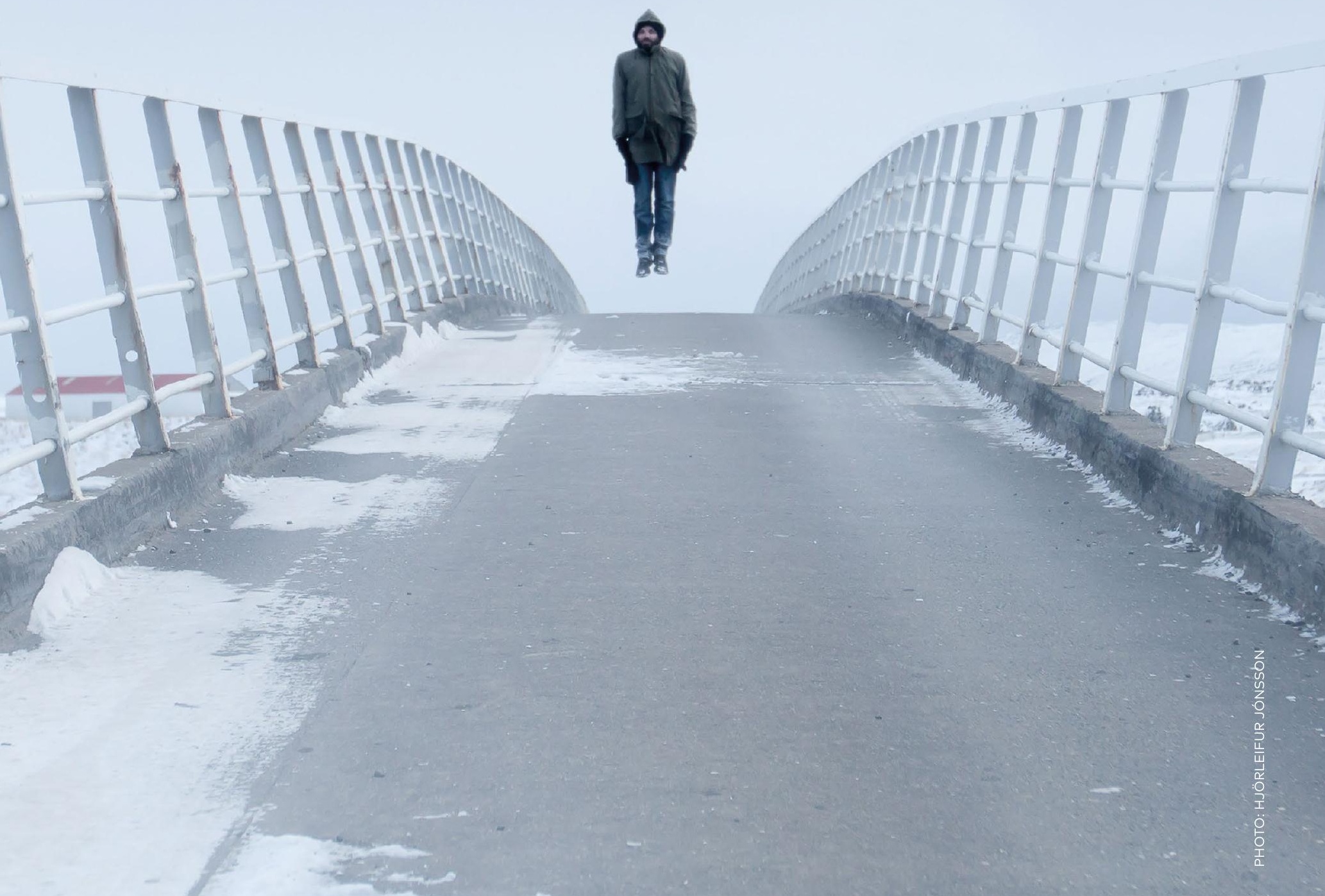


Nordic Council of Ministers

Nordens Hus

Ved Stranden 18

DK-1061 Copenhagen K

www.norden.org

Tourism is an important, growing industry in all the Nordic countries, but until recently, it has not had a particularly strong focus within the Nordic cooperation framework. This is changing rapidly, and the Nordic Council of Ministers has given a strong signal that increased emphasis should be placed on tourism issues within the Nordic framework. This project is a result of that important political prioritisation.

The key objective of this project is to create a framework on which a Nordic Tourism Strategy can be established. Thus, the desired outcome of the project is to define future strategies and projects that will underscore common opportunities and challenges within Nordic tourism. The objective of a Nordic Tourism Policy Analysis is to provide valuable input to each country's work within tourism as well as laying a foundation for a common Nordic Tourism Policy. 